NBER WORKING PAPER SERIES

\title{
DIVIDEND TAXES AND CORPORATE BEHAVIOR: EVIDENCE FROM THE 2003 DIVIDEND TAX CUT
}

\author{
Raj Chetty \\ Emmanuel Saez \\ Working Paper 10841 \\ http://www.nber.org/papers/w10841 \\ NATIONAL BUREAU OF ECONOMIC RESEARCH \\ 1050 Massachusetts Avenue \\ Cambridge, MA 02138 \\ October 2004
}

This paper is an updated and expanded version of "Do Dividend Payments Respond to Taxes? Preliminary Evidence from the 2003 Dividend Tax Cut", NBER Working Paper No. 10572. We thank Alan Auerbach, Malcolm Baker, Abhijit Banerjee, David Card, Dhammika Dharmapala, Martin Feldstein, John Graham, Day Manoli, Igor Osobov, Francisco Perez-Gonzalez, James Poterba, John Quigley, Nikolai Roussanov, Jeremy Stein, Arnold Zellner, and numerous seminar participants for very helpful comments and discussions. Bhuvan Jain, Kory Kroft, Brandon Lehr, and especially Joe Rosenberg provided outstanding research assistance. Financial support from NSF Grant SES-0134946 and the Sloan Foundation is gratefully acknowledged. The views expressed herein are those of the author(s) and not necessarily those of the National Bureau of Economic Research.

(O2004 by Raj Chetty and Emmanuel Saez. All rights reserved. Short sections of text, not to exceed two paragraphs, may be quoted without explicit permission provided that full credit, including $\odot$ notice, is given to the source. 
Dividend Taxes and Corporate Behavior: Evidence from the 2003 Dividend Tax Cut

Raj Chetty and Emmanuel Saez

NBER Working Paper No. 10841

October 2004

JEL No. H3, G3

\section{ABSTRACT}

This paper analyzes the effects of dividend taxation on corporate behavior using the large tax cut on individual dividend income enacted in 2003. Using data spanning 1980 to 2004-Q2, we document a sharp and widespread surge in dividend payments following the tax cut, along several dimensions. First, an unprecedented number of firms initiated regular dividend payments after the reform. As a result, the number of publicly traded firms paying dividends, after having declined continuously for more than two decades, began to increase precisely in 2003. Second, many firms that were already paying dividends prior to the reform raised regular dividend payments significantly. Third, special dividends also rose. All of these effects are robust to introducing controls for profits and other firm characteristics. Additional evidence for specific groups of firms suggests that the tax cut induced increases in total payout rather than substitution between dividends and repurchases. The tax response was confined to firms with lower levels of forecasted growth, consistent with an improvement in capital allocation efficiency. The response to the tax cut was strongest in firms with strong principals whose tax incentives changed (presence of large taxable institutional owners or independent directors with large share holdings), and in firms where agents had stronger incentives to respond (large executive ownership and low levels of executive stock-options outstanding). These findings show that principal-agent issues play a central role in corporate responses to taxation.

Raj Chetty Department of Economics University of California, Berkeley

521 Evans Hall \#3880

Berkeley, CA 94720

and NBER

chetty@econ.berkeley.edu
Emmanuel Saez Department of Economics University of California, Berkeley 549 Evans Hall \#3880 Berkeley, CA 94720 and NBER saez@econ.berkeley.edu 


\section{Introduction}

The taxation of dividend income has generated much interest and controversy both in the public economics literature and among tax policy makers, largely because it creates a particularly stark version of the equity-efficiency tradeoff. Dividend income, and especially taxable dividend income, accrues very disproportionately to wealthy individuals. ${ }^{1}$ Hence, taxing dividends seems desirable for redistributive reasons. However, taxing dividend income may also generate large efficiency costs. Dividend taxes reduce the net return to investors, potentially reducing savings and the capital stock in the economy. In addition, taxing dividend income at the individual level could induce firms to reduce their tax burdens by retaining earnings rather than distributing dividends. If agency problems lead to inefficient investment of retained earnings (as suggested by e.g., Jensen 1986, Scharfstein and Stein 2000, LaPorta et al., 2000), dividend taxation could reduce the efficiency of capital allocation in addition to distorting the amount of investment. ${ }^{2}$ In view of this tradeoff, it is important to know firms' behavioral responses to taxation to evaluate optimal dividend taxation. Despite extensive research, the effects of taxation on dividend policies and corporate behavior more generally remain disputed, largely because of the lack of a sharp tax experiment, and therefore of a fully convincing research design (see Auerbach (2003) and Allen and Michaely (2003) for recent surveys).

The Jobs and Growth Tax Relief Reconciliation Act of 2003 in the United States (hereafter, the "2003 tax reform") provides a unique opportunity to understand the effects of dividend taxation on corporate behavior. One of the key provisions of the reform was to introduce favorable treatment for individual dividend income whereby dividends are taxed at a rate of $15 \%$ instead of facing the regular progressive individual income tax schedule with a top rate of $35 \% .^{3}$ This tax change effectively gave to dividend income the same favorable tax treatment

\footnotetext{
${ }^{1}$ Individual Income Tax Statistics for year 2000 (U.S. Treasury Department, 2003) show that about two thirds of taxable dividends are earned by the top $10 \%$ income taxpayers. More than half of American families now hold stock through pension or college funds but returns on those assets are exempted from income taxes and hence not affected by the 2003 tax reform.

${ }^{2}$ Indeed, Corporate America has traditionally lobbied for corporate tax reductions but not dividend tax reductions, suggesting that managers of large corporations might prefer to retain earnings rather than distribute dividends.

${ }^{3}$ More precisely, taxpayers in the bottom two income tax brackets (facing a regular marginal tax rate of $10 \%$ or $15 \%$ ) face a new dividend tax rate of only $5 \%$, while taxpayers in the top four brackets (facing marginal tax rates of $25,28,33$, or $35 \%$ ) face a new dividend tax rate is $15 \%$. Taxpayers on the Alternative Minimum Tax schedule (flat rate of $28 \%$ ) benefit as well from the reduced $15 \%$ tax rate on their dividend income.
} 
as realized capital gains income. ${ }^{4}$ The tax reform was officially signed into law at the end of May 2003, but was first proposed by the Bush administration on January $7,2003 .{ }^{5}$ The tax cut on dividend income was made retroactive to the beginning of 2003. Therefore, during the first two quarters of 2003, corporations knew that dividends would face lower taxes with substantial probability. Starting in June 2003, this became certain. The tax cut is scheduled to expire by 2009 , but the actual duration is contingent on political developments. ${ }^{6}$

This paper uses the 2003 dividend tax cut to estimate the effect of dividend taxes on dividend payments by publicly traded corporations. The leading example for both the incentive and distributional consequences of the tax cut is Microsoft, the company with the largest accumulated cash holdings in the U.S. Microsoft initiated regular dividend payments for the first time in 2003. In July 2004, Microsoft announced an additional special one-time dividend payment of $\$ 32$ billion to be paid in December 2004, an amount that far exceeds any dividend payment previously made by a single U.S. corporation. The tax-savings associated with these payments will clearly benefit wealthy taxpayers disproportionately, starting with Bill Gates the richest person in the United States, but they might also affect the investment decisions of Microsoft and other companies. The goal of this paper is to examine whether Microsoft's behavior is an anomaly or whether it is representative of a broader shift in payout policies associated with the tax cut. We investigate this issue using data on dividend payments by publicly traded corporations, currently available up to the second quarter of 2004 from the Center for Research in Security Prices (CRSP).

We find that the level of total regular dividends has surged by approximately $20 \%$ since the beginning of 2003, the point at which the lower tax rate was first proposed and ultimately retroactively applied. We need to surmount two important econometric challenges in order to identify a causal link between this change and the tax reform. First, dividend payments are extremely concentrated. The top 20 payers account for more than half of total dividends

\footnotetext{
${ }^{4}$ Individual dividend income earned through tax favored instruments such as IRAs, 401(k)s and other pension and college funds was not affected by the tax change. Dividend income earned by government agencies, nonprofit organizations, and corporations was not affected either.

${ }^{5}$ Auerbach and Hassett (2004) discuss the timing of the tax reform legislative process in detail. They find that the reduction of dividend taxation was not discussed seriously before the end of December 2002. It was not mentioned in the Bush 2000 campaign platform either, suggesting that there was no anticipation that such a tax change would take place before the very end of 2002 .

${ }^{6}$ If President Bush wins again in 2004, the tax cut might well be made permanent. If Senator Kerry wins, as Congress is predicted to almost certainly remain Republican, gridlock and no further change is the most plausible outcome.
} 
paid out by publicly traded firms. Consequently, the level of total (or mean) dividends is driven by a few big payers, making it difficult to make statistically robust inferences about the effects of the tax change without analyzing other moments of the distribution that are less sensitive to outliers. Second, the size and composition of our sample of firms listed on the NYSE, AMEX, or NASDAQ exchanges fluctuates heavily in the years preceding the tax reform. As a result, deliberate changes in dividend behavior are confounded with changes in sample composition due to entry and exit. ${ }^{7}$ In view of these problems, we control for composition effects by analyzing the properties of entrants and leavers, focusing on within-firm changes in dividend payments. We also divide our analysis of the response to the tax reform into three margins that are more robust to outliers than means: (1) the extensive margin (initiations and terminations of regular dividend payments); (2) the intensive margin (frequency of increases or decreases in payment amounts by firms already paying); and (3) special payments (one time distributions). Our main findings are as follows.

First, we find an unprecedented large surge in dividend initiations exactly in the quarters following enactment of the reform. This constitutes strong evidence that this change in behavior was tax driven. As a result and as the frequency of dividend terminations fell slightly after the tax cut, the fraction of traded companies paying dividends, which had declined continuously over the last two decades (see Fama and French 2001), has increased significantly from a low of 20\% in 2002Q4 to almost 25\% in 2004Q2. Second, dividend paying firms were significantly more likely to increase their regular dividend payments after the reform. Third, we find that the number of special (i.e., one time, non-recurring) dividend payments also increased following the 2003 tax reform but the effects on special dividend amounts are driven by a handful of large payers. All of these results are robust to controlling for a variety of potential confounding factors such as levels and lags of profits, assets, cash holdings, industry, and firm age. ${ }^{8}$ In addition, we provide robustness checks of the causality of the tax cut by showing that there is no change in dividend initiations for U.S. corporations whose largest shareholder is a non-taxable institution such as a pension fund, or for Canadian corporations. By aggregating the changes in amounts along the extensive and intensive margins, we obtain

\footnotetext{
${ }^{7}$ These two econometric issues explain the sharp differences between our results and the recent studies of the 2003 tax cut by Blouin, Raedy, and Shackelford (2004) and Julio and Ikenberry (2004), which we discuss in detail below.

${ }^{8}$ Importantly, we find no pre-reform decline in dividends, suggesting that the reform was indeed unanticipated and that our estimates are not biased by intertemporal substitution (re-timing) of dividend payments.
} 
a relatively precise estimate of the change in total regular dividends due to the tax cut of $\$ 5$ billion per quarter (20\%). This implies an elasticity of regular dividend payments with respect to the marginal tax rate on dividend income of -0.5 .

Having established a link between the tax cut and dividend payments, we explore the mechanism of the tax response by analyzing the heterogeneity of the effect across firms. We find that the dividend response was concentrated among firms with strong incentives for agents to increase dividend payments or with powerful principals whose incentives to demand dividend income changed significantly with the reform. Firms where top executives held more shares and fewer unexercised stock-options were much more likely to initiate dividend payments, revealing the importance of top executives' self-interests in determining corporate responses to taxation. ${ }^{9}$ In addition, firms with high taxable institutional ownership or large independent shareholders on the board of directors were also more likely to raise dividends, especially when top executives have weak incentives to do so. These findings indicate that agency issues should be a central element in the analysis of optimal corporate tax policy, and call for a tighter connection between traditional tax efficiency analysis in public economics and the agency theory of the firm in corporate finance.

The heterogeneity of the tax response also provides suggestive evidence of an improvement in capital allocation toward firms with better investment opportunities. Dividend initiations and increases were confined to firms with moderate forecasted earnings growth. In contrast, firms with high expected growth in earnings did not respond to the tax cut at all. Of course, capital allocation could only have improved if total payout rose after the tax cut; if the surge in dividend payments simply substituted for share repurchases, no net reallocation would have occurred. We therefore explore the degree of substitution between share repurchases and additional dividend payouts. Unfortunately, the volatility of share repurchases in the aggregate makes it difficult to determine whether substitution occurred in the full sample of firms. If we restrict attention to groups of firms where the tax response was strongest - e.g., those with high executive share ownership and high institutional ownership - we are able to show that the fraction of firms using either share repurchases or dividends to pay out earnings rose sharply after the reform. In addition, for those companies who initiated dividends after

\footnotetext{
${ }^{9}$ These findings do not necessarily imply that managers are hurting shareholders by manipulating corporate decisions. It is possible that managers contracts were written so that the management's self-interest is aligned with shareholders' interests.
} 
the reform, total payout (dividends plus share repurchases) increased significantly. Hence, the tax reform does indeed appear to have induced an increase in total payout rather than simply a "relabelling" of repurchases as dividends.

The remainder of the paper is organized as follows. Section 2 provides some background on payout policies and previous work. Section 3 describes the data and defines the variables of interest. Section 4 describes our methodology and presents the main results on the change in dividend payments induced by the tax reform. Section 5 examines the heterogeneity of the response, and section 6 investigates whether new dividend payments crowded out share repurchases. Section 7 offers concluding remarks.

\section{Background on Payout Policies and Existing Literature}

\subsection{Payout Policies}

Corporations distribute profits to shareholders in two main forms: dividends and share repurchases. In a world without taxes and with perfect information, share repurchases and dividends are equivalent. Under U.S. tax law, because realized capital gains have traditionally been taxed more lightly than dividend income, share repurchases were a more tax efficient way of distributing profits. Share repurchases started becoming more common in the early 1980s following a SEC ruling in 1982 which clarified the rules under which corporations could legally make share repurchases without being subject to dividend taxation (Grullon and Michaely, 2002). However, despite the rise in share repurchases, dividends have remained an important conduit for distributing profits. ${ }^{10}$ The reason why dividends have not been entirely replaced by share repurchases has been termed the "dividend puzzle," and a number of theories and explanations have been proposed to explain this phenomenon (see Michaely and Allen, 2003). The 2003 tax reform almost eliminated the tax disadvantage of dividends relative to repurchases.

There are two broad categories of dividend payments: regular dividends and special dividends. Regular dividends are periodic and recurrent (in general quarterly but sometimes annual, semi-annual, or more rarely monthly). As noted by Fama and French (2001), the fraction of publicly traded firms making these regular dividend payments is fairly low (less than

\footnotetext{
${ }^{10}$ Over the last decade, total dividend payouts are about the same size as total share repurchases for publicly traded U.S. corporations (see Michaely and Allen, 2003) and Section 6 below. Grullon and Michaely (2002) argue that share repurchases have, to some extent, crowded out dividend payments.
} 
$25 \%$ ) in the recent past. It is fairly common for firms to increase regular dividend payments - $11 \%$ of firms initiated or raised dividends in the average quarter. Decreases are much rarer (less than 2\% per quarter), consistent with DeAngelo and DeAngelo's (1990) finding that only severely distressed firms lower or terminate dividend payments. Regular dividends are thus extremely persistent over time. ${ }^{11}$ Hence, an initiation of a regular payment (as by Microsoft in 2003) is a strong signal that the firm intends to maintain a dividend payment of equal or greater value permanently.

In contrast to regular dividends, special dividends are one-time, non-recurring events. Special payments are made by very few firms ( $0.8 \%$ of our sample). Special dividends are also generally of minor importance in terms of amounts relative to regular dividends, accounting for less than $2.5 \%$ of total dividends on average.

\subsection{Previous Work}

Most of the early work on the effects of taxation on dividend payments used time series analysis rather than focusing on a single tax reform. The evidence from this literature is controversial, and is typically divided into the "old view" and the "new view." 12

The old view, implicit in Feldstein (1970), says that dividend taxes reduce the net return on investment and hence reduce the supply of investment. Therefore, when taxes on dividends are cut, individuals are more willing to save and invest their money in stocks, spurring business investment, profits, and dividend distributions in the long run. Poterba and Summers (1985), using time series evidence from the United Kingdom found that, consistent with the old view, dividend payments and investment were higher when the tax rate on dividends was lower. More recently, Poterba (2004) uses U.S. time series data from 1929 to 2002 and finds a negative association between dividend payments and the dividend tax rates relative to taxes on capital gains. His point estimates imply that the 2003 tax reform should increase dividend payments by $20 \%$ in the long run, but that the adjustment process will be very slow, with only a quarter of the long-run effect taking place within three years. ${ }^{13}$

\footnotetext{
${ }^{11}$ Section 3 gives formal definitions of initiations and terminations.

${ }^{12} \mathrm{~A}$ large related literature studies the effects of taxes on other corporate behaviors such as investment (Cummins et al. 1994, Desai and Goolsbee, 2004), capital structure (Gordon and Lee, 2001), and organizational form choices (Gordon and MacKie-Mason, 1990, Goolsbee, 1998, 2004).

${ }^{13}$ Our estimates also point toward a $20 \%$ increase in dividend payments but the response we document happens much faster than the one predicted by Poterba's estimates.
} 
In contrast, the new view on dividend taxation, implicit among critics of the 2003 tax reform, assumes that marginal investments are entirely financed by retained earnings rather than new share issues (Auerbach (1979), King (1977), and Bradford (1981)). Under this assumption, the tax on dividends should not affect the investment decisions of firms, and profits and dividend payments therefore should not change either. ${ }^{14}$ In this case, the dividend tax cut is irrelevant for corporate decisions and simply benefits individual investors by reducing their tax burden. Using U.S. data from 1981 to 1998, Auerbach and Hassett (2003), show that consistent with the new view, dividend payments are sensitive to changes in investment at the firm level, suggesting that retained earnings are indeed the marginal source of investment funds. Auerbach (2001) critically reviews the time series empirical literature and concludes that the evidence for a large dividend payout response to dividend taxation is at best mixed.

In light of the difficulties with time series analysis, another strand of the literature has attempted to use the variation in tax rates induced by the Tax Reform Act of 1986 (TRA-86) to study these issues, but has also found mixed results. TRA-86 cut the top income tax rate from $50 \%$ to $28 \%$ while increasing the tax rate on capital gains from $20 \%$ to $28 \%$. Bolster and Janjigian (1991) find no discernible effect of TRA-86 on aggregate dividend payments by publicly traded firms. However, in an innovative study, Perez-Gonzalez (2003) showed that there was a small response of dividend payments among a subsample of firms with large individual shareholders, which is masked in the aggregate. Our analysis shows that TRA-86 generated a short-term spurt of special dividend payments concentrated among a very small number of firms but, in contrast to the 2003 tax reform, had no discernible effect on regular dividend payments. ${ }^{15}$ Consistent with Perez-Gonzalez's (2003) evidence for TRA-86, we also find that the response to the 2003 tax reform is larger for companies with large shareholders on the board of directors or among top executives.

Finally, a few very recent studies have also investigated the effect of the 2003 tax reform on dividend policies. ${ }^{16}$ We discuss how our study differs, complements, or disagrees with these

\footnotetext{
${ }^{14}$ However, as pointed out by Auerbach and Hassett (2003), if the tax reform not only changes dividend income taxation but also interest income taxation (as in the Tax Reform Act of 1986) or if the tax reform is not permanent but temporary (as might be the case with the 2003 tax reform), then even under the new view dividend payments may change following a dividend tax change.

${ }^{15}$ We discuss reasons why TRA-86 may have had different effects than the 2003 reform in section 4 .

${ }^{16}$ With the exception of Blouin et. al (2004), these studies were completed at roughly the same time as our own study, and were brought to our attention after we circulated our preliminary results in Chetty and Saez (2004).
} 
concurrent studies in this subsection as well as in the context of our results in section 4 .

First, Blouin, Raedy, and Shackelford (2004) examined dividend payments in the three months immediately after the tax reform was passed (May 23 to August 22, 2003). They compared dividend payments in this post-reform period with dividends in the same period in 2002 (May 23 to Aug. 22, 2002) and the three month period immediately preceding enactment of the reform. Blouin et. al. concluded that virtually all the increase in dividend payments after the tax reform was due solely to 17 firms who paid special dividends, and found no statistically significant changes in regular dividend amounts. Their results differ from our results for a number of reasons. First, they choose their sample by selecting all firms alive from 2001-Q4 to 2003-Q3 that paid dividends in the three months after enactment. This sample selection is based on the endogenous post-reform dividend choice and is likely to bias their results. Second, they focus on the level of dividends payments (and then separate regular and special dividends), rather than other moments of the distribution. As emphasized above, analyzing the effect of the tax cut on regular dividend levels is a difficult statistical problem because of the large outliers that drive the means. ${ }^{17}$ Indeed, when analyzing our data at a monthly level, we find that the surge in the frequency of regular dividend initiations and increases began precisely in the post-reform period studied by Blouin et. al. Third, they do not look back at the historical data before 2002. Again, since aggregate regular dividends are a noisy time series, it is difficult to assess the magnitude of the response induced by the tax change without making further historical comparisons. Finally, three more quarters of post-reform data have become available since their study. The additional data show that the rapid growth in regular dividend payments that began during the period examined by Blouin et. al. has continued in subsequent quarters.

Second, Julio and Ikenberry (2004) extend the influential time series analysis of Fama and French (2001) up to the first quarter of 2004. They show that the secular downward trend in the fraction of listed firms paying dividends makes a reversal starting in late 2000. Julio and Ikenberry argue that the Bush dividend tax cut cannot explain the reversal, as it starts well before tax reform occurred. They propose various explanations for the pre-tax rebound, including corporate accounting scandals and the maturity of technology firms. In contrast,

\footnotetext{
${ }^{17}$ Blouin et al. also find similar results for dividends per share, but this is not an economically relevant normalization as the number of shares in public corporations is to a very large extent arbitrary.
} 
we show that the reversal in 2000 in the fraction of publicly traded firms paying dividends is entirely due to changes in the composition of the sample due to the de-listing of many young technology firms during the stock market crash of 2000-2001. These firms generally did not pay dividends, mechanically raising the fraction of payers. When controlling explicitly for these entry and exit effects, we find that the reversal in the secular decline in the number of payers takes place exactly in 2003. This result is not surprising in light of our finding that initiations surge only in 2003 while terminations remain stable. ${ }^{18}$

Finally, Nam, Wang, and Zhang (2004) show that executive ownership is correlated with dividend increases in 2003 but that there was no such relation in previous years. Their results are consistent with our findings about the importance of principal-agent issues in determining the tax response. However, Nam et. al. limit their analysis to executive share and stock-option ownership compiled from Execucomp data for about 1,500 firms every year since 1992, and only to firms already paying dividends. ${ }^{19}$ In this paper, we focus on the dividend initiation margin, along which the tax response was by far the most striking. We also consider heterogeneity along other dimensions, such as large shareholders (individual and institutional, taxable versus non-taxable). We also collect executive share and stock-option ownership for a much larger set of firms from proxy statements in order to obtain estimates for the full sample of publicly traded firms. These additional data also allow us to provide results on interaction effects between executive share ownership and the strength of principals that are not evident in the selected sample of firms listed in ExecuComp.

\section{Data}

We use quarterly data from the CRSP, which reports dividend, stock price, and share information for all companies listed on the NYSE, AMEX, and NASDAQ stock exchanges. The data we use span 1980-Q1 to 2004-Q2, the last quarter for which data are currently available. Following Fama and French (2001) and Auerbach and Hassett (2003), we exclude all foreign firms and all firms whose most recent industry classification is in utilities (SIC codes between 4900 and 4949) or the financial sector (SIC code between 6000 and 6999) because these com-

\footnotetext{
${ }^{18}$ Consistent with our results, Julio and Ikenberry (2004) also find that there was a surge in dividend initiations only in 2003 and not at the time of the 2000 reversal.

${ }^{19}$ More recently, Brown, Liang, Weisbenner (in progress, no draft yet available) have also noticed that executive ownership is related to dividend initiations and dividend increases after the tax reform.
} 
panies are regulated and often have legal distribution requirements. Their dividend payments may therefore be determined by law rather than by shareholder decisions. ${ }^{20}$ The sample of firms that satisfy the preceding criteria constitute our "core sample."

The number of firms in the core sample in each quarter varies between less than 4,000 in the early 1980s and about 6,000 in the late 1990s (see Appendix Table A1 in and Figure 6, Panel B for a graphical depiction). There are large variations in the number of listed firms because of waves of new lists during some periods (in general during economic booms) and waves of de-listing in some other periods (in general during recessions and stock market crashes). The large variation over time in the number of firms in the core sample raises important issues in the empirical analysis. As we show below, it is often useful for comparability to keep the same number of firms in each quarter. To obtain the largest possible constant-size sample of firms, we focus on a sample of the top 3,807 firms ranked by market capitalization in each quarter, which we term the "constant number of firms" sample. ${ }^{21}$

For our regression and heterogeneity analysis, we merge our CRSP sample with the Compustat database, losing some firms because not all firms listed in CRSP are covered by Compustat. Compustat data were available only up to 2004-Q1 when this study was completed. The left half of Table 1 gives summary statistics for the core and the constant number of firms samples between 1981-Q3 and 2004-Q1. ${ }^{22}$ All dollar amounts in this and subsequent tables and graphs are in real 2004 dollars (deflated using the Consumer Price Index). We also merge our data with various other databases that contain other covariates of interest. The I/B/E/S database gives analysts' earnings forecasts for approximately $60 \%$ of the companies in our sample. Execucomp provides detailed executive compensation, stock and stock-option ownership for approximately one-third of the firms in our sample every year since 1992. Thompson Financial database provides detailed institutional ownership information for most of the firms in our sample. Dlugosz, Fahlenbrach, Gompers, and Metrick (2004) provide information on large shareholders (individuals or entities who hold more than $5 \%$ of shares), collected from proxy statements, for about 1,500 firms for the period 1996-2001. Because Execucomp and the Dlugosz, et. al. database cover only about a third of the CRSP-Compustat firms, we augment

\footnotetext{
${ }^{20}$ We also examined utilities and financial firms separately and our results for those firms are available upon request.

${ }^{21} 3,807$ is the total number of firms which meet our selection criteria in 2004-Q2, the last quarter available. For all previous quarters, the CRSP data always contains at least 3,807 firms.

${ }^{22}$ Lagged data requirements for our subsequent analysis force us to begin with 1981-Q3.
} 
these data sources for our principal-agent heterogeneity analysis by collecting some variables directly from SEC proxy statements for an additional 347 firms, as described in Section 5.

We define regular dividends as monthly, quarterly, semi-annual, and annual taxable dividends in the CRSP data. We also reclassify "other frequency" taxable dividends as regular dividend payments when those other-frequency payments are followed by regular payments of similar magnitude. ${ }^{23}$ Some forms of liquidation can generate non-taxable dividend events that we ignore in this study. We define all other taxable dividends besides regular distributions as "special" dividends. More precisely, we define special dividends as the sum of special, one-time, unspecified and other frequency dividends (those which were not followed by regular payments of similar magnitude) in the CRSP data. Virtually all payments in our broader definition of special dividends are accounted for by CRSP's "special dividend" category.

We define a firm as initiating regular dividend payments in quarter $t$ if it pays positive regular dividends in quarter $t$ and did not pay dividends in the previous four quarters. We define a firm as terminating regular dividend payments in quarter $t$ if it paid regular dividends previously and stops paying from quarter $t$ on. In practice, our definitions are slightly more complex to accommodate the case of annual and semi-annual payers as well as the issue of censoring (for terminations only) at the end of the sample. The exact definitions are presented in appendix.

\section{Effect of the Tax Cut on Dividend Payments}

Our empirical analysis is organized as follows. The first subsection examines the change in aggregate dividend amounts following the 2003 tax change and demonstrates the need to examine other moments of the dividend distribution to make reliable inferences about the effects of the tax reform. Subsections 2-4 provide such an analysis along three margins: (1) the extensive margin (initiations and terminations of regular dividend payments); (2) the intensive margin (increases or decreases in payment amounts by firms already paying); and (3) special dividends. Subsection 5 shows that dividing the analysis into these margins allows a fairly precise assessment of the contribution of each of the three margins to total dividend amounts, and reports an elasticity of dividend payments with respect to the dividend tax rate using this

\footnotetext{
${ }^{23}$ This other-frequency dividends are extremely rare and thus our results are not sensitive to the way we treat them.
} 
method. Finally, we discuss robustness checks of the causality of the tax cut in subsection 6 .

\subsection{Aggregate Dividends}

Figure 1 plots aggregate regular dividends for the core sample between 1981-Q3 and 2004-Q2 in real 2004 dollars (using the CPI deflator). Total regular dividends rose from $\$ 25$ billion in 2002 to a peak of almost $\$ 30$ billion at the end of 2003. Note that most of the increase takes place in the last two quarters of 2003 after the tax cut was signed into law in July, 2003. These are the largest increases during the sample period. If the post-2003 increases in aggregate dividends are due exclusively to the tax cut, these values suggest that the reform raised regular aggregate dividends by about $20 \%$ in the six quarters after the reform relative to the level in 2002-Q4 . Unfortunately, it is difficult to determine whether this surge in aggregate dividends is tax-driven simply by examining changes in mean dividend amounts paid by publicly traded firms. The econometric problem can be easily illustrated using data in the years around the tax reform with regressions of the following form:

$$
\operatorname{totdiv}_{i, t}=\alpha+\beta r e f d u m_{i, t}+\gamma X_{i, t}+\varepsilon_{i, t}
$$

The dependent variable is total dividends paid by firm $i$ in quarter $t$. The regressor of interest is the reform dummy: refdum $i, t=0$ in the four quarters before discussion of the reform (2002-Q1 to 2002-Q4), while refdum ${ }_{i, t}=1$ in the four quarters after enactment (2002-Q1 to 2002-Q4). ${ }^{24}$ Without controls (no $X \mathrm{~s}$ ), the OLS estimate of $\widehat{\beta}=1.58$ (s.e. $=0.23$ ). ${ }^{25}$ In contrast, introducing a linear control for after tax earnings gives $\widehat{\beta}=0.62$ (s.e. $=0.62$ ), and an additional control for assets changes the estimate to $\widehat{\beta}=-0.06$ (s.e. $=0.3$ ).

This fragility of the estimate of the tax response arises from the extreme concentration of dividend payments. Figure 1, which also plots regular dividend amounts paid by the top 20 payers in each quarter, shows that the dividends from the top 20 payers account for half of all dividends paid by all firms in our core sample. The fact that this concentration is the source of the imprecision in $\widehat{\beta}$ becomes evident when we change the dependent variable in (1) to dividend yield (total dividends divided by mktcap). In the dividend yield regressions, which

\footnotetext{
${ }^{24}$ For simplicity, we ignore all other quarters in this exercise. However, inclusion of the full data from 1980-Q1 to 2004-Q2 along with appropriate controls for year trends does not change our conclusions: the point estimates of $\beta$ remain statistically insignificant and fragile as soon as controls are introduced.

${ }^{25}$ Standard errors reported here are clustered by quarter to allow for aggregate shocks. Standard errors under the i.i.d. error assumption are even larger than those reported here.
} 
are simply re-weighted versions of 1 ) with less weight on large firms, we obtain very stable estimates of the $\beta$ coefficient that are statistically significant at the $1 \%$ level, irrespective of controls. Intuitively, mean dividends are driven in large part by very few top payers, creating a small sample problem that makes statistical inference about the level of aggregate dividends difficult. In view of this problem, we must turn to other moments of the dividend distribution to obtain more credible evidence on whether the 2003 tax reform changed corporate payout behavior.

\subsection{Extensive Margin}

One straightforward way of reducing the influence of very large payers is to examine a firm's decision to initiate or terminate dividend payments rather than looking at the amounts paid. We first examine changes in initiations and terminations, and then discuss implications for the overall fraction of dividend payers.

\subsubsection{Initiations and Terminations}

Figure 2 plots the fraction of initiations and terminations of dividend payments in the constant number of firms sample. It is clear that the frequency of initiations rose when the reform was proposed (2003-Q1) and surged very sharply after it was enacted. Strikingly, the number of initiations in the three quarters following enactment (2003-Q3, 2003-Q4, and 2004-Q1) are the three highest among the 80 quarters we consider (see Appendix Table A2 for the full time series of initiations and other variables of interest). Importantly, there is no sign of a decline in initiations prior to the reform, suggesting that the sharp surge in initiations reflects real behavioral responses to an unanticipated change rather than a timing effect due to firms that were delaying initiations in anticipation of the tax reform. Meanwhile, the number of terminations remained very low and, if anything, fell slightly after the reform.

The initiations were widespread across industries and sizes of firms. Table 2 lists the post-reform initiating firms among the largest 100 firms in our sample (ranked by market capitalization in 2004-Q2). It shows that large initiators were not concentrated in a single sector and that the dividend yields in the first year were not trivial, although lower than for established payers among the top 100.

Table 3 summarizes the magnitude of the effect by comparing dividend initiations during 
a short window around the reform-period. The pre-reform period is taken as the six quarters before the reform 2001-Q3 to 2002-Q4 and the post-reform period includes the six post reform quarters, 2003-Q1 to 2004-Q2. The first row of Table 3 shows that the average number of initiations surged from 4.3 per quarter in the pre-reform period to 29 after the reform. The difference is highly statistically significant (t-statistic over 10). Of course, the conclusion that this change was entirely due to the tax reform is predicated on the assumption that no other unobservable determinant of dividend payments changed contemporaneously. To examine the validity of this assumption, we evaluate the robustness of our results to the inclusion of a rich set of control variables identified as determinants of dividend policy by Lintner (1956) and summarized more recently in Brav, Graham, Harvey, and Michaely (2002). We run the following semi-parametric regression specification for initiations:

$$
\text { Init }_{i, t}=\sum_{s=1}^{T} \beta_{s} \cdot 1(t=s)+\mu^{a} a_{i, t}+\sum_{s=0}^{8} \mu_{s} X_{i, t-s}+\sum_{s=0}^{8} v_{s}^{S} S I C_{i, t}^{s}+\varepsilon_{i, t}
$$

where Init $_{i, t}$ is an initiation dummy which takes value 1 if firm $i$ initiates dividend payments in quarter $t$ and zero otherwise, $1(t=s)$ are a full set of quarter dummies. The additional firm-level covariates are: (1) total current assets, $a_{i, t}$; $(2)$ the level and eight lags of quarterly profits/assets, market capitalization/assets, and cash holdings/assets, (vector $X_{i, t}$ ); and (3) First-digit SIC industry dummies, $S I C_{i, t}^{s}$ that indicate whether the first digit of firm $i$ 's SIC code is $s$ in 2004 .

Figure 3 shows that the surge in initiations is extremely robust to adding these controls by plotting the $\left\{\beta_{s}\right\}$ coefficients from the regression along with the mean estimates of initiation rates displayed in Figure 2. ${ }^{26}$ In addition, the fourth column of Table 3 shows that adding controls does affect the estimate of the change in dividend initiations between the six-quarter pre and post reform periods. The estimates reported in this column are from a regression specification equivalent to (2) except that the quarter dummies are replaced with a single post-reform dummy. Therefore, the surge in initiations cannot be explained by changes in firms' balance sheets or investment prospects in the post-reform period. ${ }^{27}$ We also examine

\footnotetext{
${ }^{26}$ The regression estimates end in 2004-Q1 because Compustat data are not yet available for 2004-Q2.

${ }^{27}$ The results are also robust to trends in mergers and acquisitions that could lead to changes in dividend policy. Among all initiators in the post reform period, only one firm acquired another company just before initiating dividends. In addition, controlling for forecasted growth prospects using I/B/E/S data on analysts' forecasts has no effect on the results.
} 
whether the innovative "catering theory" of dividend initiations recently proposed by Baker and Wurgler (2004a,b) may explain our results. We find that their leading measure of the markets' preference for the dividends - the dividend premium, which is defined as the log difference in market to book ratios for dividend payers and non-payers - does not predict the recent surge. ${ }^{28}$ These results confirm that observable trends are not responsible for the recent surge in dividend initiations; we defer discussion of bias from unobservable trends to section 4.6 .

To contrast our results with Blouin et al. (2004), who found no evidence of increases along the regular dividend margin, we examine the data at a monthly frequency in the months around the passage of the reform. Figure 4 plots the number of initiations per month between 2001 and 2004. It is clear that the surge in initiations occurred shortly after the reform was enacted, during the three month period examined by Blouin et. al. Hence, although the addition of three more quarters of data has made the increase in regular dividend payments after the tax cut clearer, the primary reason that our conclusions differ from those of Blouin et. al. is the difference in methodology. Changes in regular dividend amounts are difficult to detect because of the extreme values problem, but changes in the number of payers are much easier to see.

\subsubsection{Fraction of Payers}

We expect the surge in initiations in the post reform period accompanied with no increase in terminations to lead to an increase in the fraction of firms paying dividends. This is confirmed in Figure 5 which plots the fraction of dividend payers in the constant number of firms sample between 1981-Q3 and 2004-Q2. As discussed in Fama and French (2001), the fraction of dividend payers has declined steadily over the past two decades, from more than $40 \%$ in the early 1980 s to less than $20 \%$ in $2000 .{ }^{29}$ The decline in the fraction of payers stops precisely

\footnotetext{
${ }^{28}$ This is because the dividend premium fell sharply during the dot-com boom and rose back to its original level during the subsequent dot-com bust. We verify that this temporary fluctuation does not predict the surge in initiations a year later by regressing the initiation rate on the dividend premium and finding that the residuals from this regression spike up sharply after the tax reform. Note that we cannot directly include the dividend premium in the semi-parametric specification in (2) because there is no within-quarter variation in the dividend premium.

${ }^{29}$ DeAngelo, DeAngelo, and Skinner (2003) emphasize that while the number of payers among publicly traded firms has fallen, dividends are not "disappearing" because total aggregate dividends have actually risen (as shown in Figure 1). This is because the distribution of dividend payments is more concentrated now than it was in 1980 .
} 
until the last quarter of 2002, at which point the fraction of payers begins to rise. Figure 5 also plots the tax preference parameter computed by Poterba (2004), which equals the net return to investors from a dollar paid in dividends instead of capital gains. ${ }^{30}$ The largest change in the tax preference parameter during the sample period occurs at the end of 2003, after which dividend payments become start to become more common.

As mentioned in Section 2.2, a recent study by Julio and Ikenberry (2004) argues that the reversal in the fraction of firms paying dividends takes place in late 2000 rather than in 2003, and hence cannot be attributed to the tax reform. It is therefore critical to understand the difference between their findings and ours. We start by reviewing Julio and Ikenberry's (2004) evidence. Figure 6, Panel A displays the fraction of regular dividend payers in the core CRSP sample and for the top 1,000 firms (ranked by market capitalization in each quarter). Indeed, in these two samples, the reversal takes place in 2001-Q1 and 2000-Q2 respectively.

Figure 6, Panel B displays the time series of the total number of firms as well as the total number of regular dividend payers in the core CRSP sample. The total number of dividend payers starts to increase (after a secular decline) only in 2003-Q1, exactly when the tax reform takes place, and accelerates after enactment. However, the number of firms in the core sample falls precipitously starting in 2000-Q4 (from 5,306 in 2000-Q3 down to 3,807 in 2004-Q4), exactly at the time the early reversal takes place for the full sample on Panel A. Only $2 \%$ of the 2,000 firms which exit the core CRSP sample from 2000-Q4 to 2004-Q4 are dividend payers. Thus, what drives the pre-2003 reversal for the full sample is a fall in the denominator (total number of firms) and not an increase in the numerator (number of payers). Therefore, this early reversal cannot be attributed to active behavioral changes in corporate payout policy.

In the case of the top 1,000 firms, the denominator is fixed, and hence the preceding story clearly cannot explain the early reversal effect for this sample. Figure 7 explores compositional changes among the top 1,000 firms. It plots, for each quarter, the number of entrants into the top 1000 which are regular dividend payers and the number of leavers which were regular dividend payers. The graph shows that there are more dividend payers which leave the top 1,000 group in 1998 and 1999 than dividend payers which enter the sample. In 2000-2002 the

\footnotetext{
${ }^{30}$ Formally, the tax parameter is defined as the dollar weighted average (across individual and institutional investors) of $\left(1-\tau_{d i v}\right) /\left(1-\tau_{c g}\right)$ where $\tau_{d i v}$ is the marginal tax rate on dividend income and $\tau_{c g}$ is the marginal tax rate on capital gains.
} 
situation is reversed: more dividend payers enter the sample than dividend payers leave. ${ }^{31}$ Through these composition effects, the number of dividend payers among the top 1,000 falls quickly in 1998 and 1999 and then recovers in 2000-2002, explaining the Julio-Ikenberry reversal effect for the top 1000 depicted on Figure 6, Panel A.

Figure 8, Panel A makes this point more formally. The first curve depicts the number of payers among the top 1,000. The "cumulative net payers listed" curve depicts the cumulative difference (from 1982-Q1) between the number of regular dividend payers who entered the top 1,000 firms and the number of regular dividend payers who left the top 1,000 firms. ${ }^{32}$ This curve captures the change in the number of dividend payers due to changes in the composition of the top 1,000 firms sample over time. As described above, the cumulative net payers listed falls in 1998 and 1999 and then rebounds in 2000-2002. The third "deliberate payers" curve is simply the difference between the first two curves. This series reflects the number of "deliberate" payers because movements in this series only come from active changes in dividend policy by firms, given that entry and exits effects have been netted out. The number of deliberate payers declines slowly until 2002-Q4 and starts increasing exactly in 2003-Q1, at the time the reform takes place. The number of deliberate payers rises by $10 \%$ from 2002-Q4 to $2004-\mathrm{Q} 2$.

Figure 8, Panel B graphs the number of deliberate payers for two other samples of interest: the core sample (all firms in the CRSP which meet our criteria) and the constant number of firms sample (the top 3,807 firms in each quarter ranked by market capitalization). For both of these samples as well, once we control for composition effects, the number of payers starts to increase in 2003-Q1, when the reform takes place, and the increase accelerates sharply in 2003-Q3, after enactment of the reform. The increase in the fraction of deliberate payers after the reform is also around $10-12 \%$ for these groups.

These results show that the early reversal findings of Julio-Ikenberry are fully explained by composition effects. Once these effects are controlled for, the reversal takes place exactly

\footnotetext{
${ }^{31}$ Examining the characteristics of the entrants and leavers, we find that the spike in dividend leavers is due to the surge in the stock prices in 1998 and 1999 of new technology firms that never paid dividends, which entered the top 1,000 and displaced older, more traditional firms (many of which paid dividends). Symmetrically, the spike in entrants is due to technology stock market crash in 2000-2002 during which new technology firms (predominantly less than 3 years old and with SIC 7370) are displaced by the original, older firms.

${ }^{32}$ This graph is equal to the integral of the difference between the two graphs (dividend payers entering and dividend payers leaving) depicted on Figure 7.
} 
after the 2003 reform is implemented, implying that deliberate changes in corporate payout behavior began only after the tax reform. ${ }^{33}$ Notably, for our constant number of firms sample (the top 3,807 firms in each quarter), composition effects cancel out and the timing and size of the surge in the number of payers and deliberate payers are almost identical. ${ }^{34}$ This justifies our focus on this group as a simple but valid way to control for entry and exit effects.

\subsection{Intensive Margin}

Given the extreme values problem that plagues the analysis of levels, we begin our study of the intensive margin by examining the effect of the tax cut on the probability that a firm increases or decreases dividend payments by more than $20 \%$ in nominal terms. ${ }^{35}$ In order to avoid double counting, initiations (terminations) are not counted as dividend increases (decreases). The appendix gives the exact definition of increases and decreases we use.

Figure 9, Panel A, plots the fraction of firms in the constant number of firms sample that increased or decreased dividends by $20 \%$ or more along the intensive margin. There is a sharp surge in the number of firms which increase dividends when the tax cut is enacted in 2003-Q3. The number of these large intensive margin increases jumped from 19 in the pre-reform period (2001-Q3 to 2002-Q4) to 50 per quarter in the post-reform period (2003-Q1 to 2004-Q2), as shown in Table 3. Analysis of the data at a monthly frequency (not reported) shows that the pattern of dividend increases coincides very closely with the pattern of dividend initiations. In particular, it began in the three month period immediately after the reform examined by Blouin et. al., and remains strong through the end of the sample period. Meanwhile, the frequency of dividend decreases remained small and essentially unchanged after the tax cut.

Figure 9, Panel B shows that controlling for observable variables from Compustat does not modify our conclusion that this increase was tax-driven. The coefficients plotted in this Figure

\footnotetext{
${ }^{33}$ An alternative way of purging composition bias is to control for firm fixed effects. Reassuringly, this method also yields similar results (the increase in the fraction of payers coincides precisely with the reform). We focus on the "deliberate payers" approach here primarily because it is much more parsimonious, giving a simple illustration of why sample composition bias leads to a pre-tax reversal.

${ }^{34}$ This can be seen formally in appendix Table A2 which displays the key quarterly series for the constant number of firms sample, including the number of dividend payers among entrants and leavers.

${ }^{35}$ Other cutoffs, such as $0 \%, 10 \%$, or $50 \%$ also yield similar results. We focus on the $20 \%$ here cutoff because these changes are both relatively frequent and sufficiently large that they are likely to signal a substantial shift in a corporation's distribution policy. Note that Julio and Ikenberry (2004) argue that the number of $0 \%$ increases started to rise in 2002 , but this conclusion is fully driven by the functional form of their data smoothing algorithm. Semi-parametric analysis shows that the surge in increases begins only after the reform was enacted.
} 
are obtained by running a regression analogous to (2) with an intensive increase dummy as the dependent variable It should be noted, however, that the evidence of a tax effect on the intensive margin is weaker than that for initiations because there were periods in the 1980s where the fraction of firms increasing dividend payments was higher than in the post-reform period. Table 3 shows that the change pre-post reform of intensive increases is also robust to adding controls.

Figure 10 gives a more complete view of the changes in dividend behavior on the intensive margin by displaying various percentiles of the dividend distribution among the top 3,807 firms (including the zeros). The level of each percentile has been normalized to one in 1998-Q1. There is clear evidence of a sharp increase in dividends for all percentiles below the percentile 99.5. The noise in the 99.5 percentile is so large that it is impossible to determine whether the changes after the reform are anything more than a random fluctuation. But the 99.5 percentile is very important for amounts, given the concentration of dividend payments: About half of all dividends are paid out by the top $0.5 \%$ dividend payers (the top 19 payers in our constant number of firms sample). The fact that the amounts are driven to a significant extent by a few big payers whose aggregate dividend payments fluctuate sharply over time explains why it is so difficult to obtain reliable estimates of the effect of taxes on mean levels. It also underscores the importance of examining other, more stable moments of the dividend distribution.

\subsection{Special Dividends}

We now turn to special, one-time dividend distributions. Figure 1 plots the total amounts of special dividends paid out. Special dividend amounts increased after enactment of the 2003 reform but there are other periods (such as the late 1980s) when special dividends were substantially higher. Indeed, TRA-86 does appear to have generated a temporary surge in the total amount of special dividends in the late 1980s much larger (and concentrated among very few firms) than after the 2003 tax reform. ${ }^{36}$ Figure 11 plots the fraction of special dividend

\footnotetext{
${ }^{36}$ It is striking that TRA-86, a permanent tax change, created only a short-term response along the special margin, while the 2003 tax change, whose duration remains somewhat uncertain, has generated substantial increases in regular dividends that are likely to be long-term. Candidate explanations for the different responses include: (1) TRA-86 changed the tax rate on interest and dividend income simultaneously, perhaps inducing broader shifts in capital structure toward debt that necessitated large one-time distributions but made increased regular dividends undesirable; (2) Average cash holdings were unusually high before the 2003 reform relative to prior years, giving firms the resources necessary to raise dividends; (3) Highly publicized cases of corporate mismanagement such as Enron may have raised the signal value of dividends, giving firms a strong reason to raise dividends as soon as the cost of doing so was lowered. Further research is required to determine which of
} 
payers in the constant number of firms sample. There is a clear surge in the fraction of special payers immediately after the reform, and this change is robust to the inclusion of controls as above. As shown in Table 3, an average of 18 firms per quarter paid special dividends after the reform, significantly greater than the average of 7 in the six quarters before. However, there are an average of 40 special dividend payments per quarter in the entire sample between 1981 and 2003. Hence, while the frequency of special payments rose after the reform relative to the recent past, it does not exceed the level of special payments in earlier periods such as the late 1980s and early 1990s.

\subsection{Changes in Amounts and Elasticity Estimates}

How much did each of the three margins discussed above contribute to the surge in aggregate dividends? To obtain a statistically precise answer to this question, we focus on deliberate changes in dividend amounts along each margin in the constant number of firms sample, and exclude firms who acquired another company in the previous quarter in order to avoid imputing dividend increases to the acquisition of a dividend paying company.

Figure 12A depicts the amounts (in real 2004 dollars) of regular dividends initiated in each quarter from 1990-Q1 to 2004-Q2. ${ }^{37}$ The amounts raised from dividend initiations surged sharply after the reform, from $\$ 13$ million per quarter in the pre-reform period to an average of $\$ 205$ million per quarter after the reform (see Table 3). Strikingly, the 6 largest initiation amounts since 1990 take place exactly in the last 6 post reform quarters. This difference is highly significant and robust to introducing the rich set of controls used in (2), as shown in Table 3. Note that there is no dip in the amount of dividends from initiations prior to the reform, suggesting that our estimates are unlikely to be biased by re-timing effects.

Figure 12A also depicts the change in regular intensive dividends for firms previously paying regular dividends. The change is estimated as the current payment less the previous regular payment (initiations and terminations are excluded). If the firm did not exist in the prior period, or drops out of the sample, the change is defined as 0 . Defining changes in this way is analogous to controlling for sample composition, because the change in the level of dividends due to entry and exit effects is ignored. The series of aggregate changes along the intensive these explanations is most relevant.

${ }^{37}$ Annual dividends are divided by four and semi-annual dividends divided by two in order to normalize changes at the quarterly level. 
margin also displays a sharp increase in levels in the 6 quarters following the reform: 4 of the 5 largest intensive increases took place in the 6 post reform quarters. Table 3 shows that intensive changes surged from $\$ 130$ million per quarter on average before the reform to $\$ 740$ million after. As with the extensive margin, the change does not reflect intertemporal substitution of dividend payments, since the series is flat in the years preceding the reform. The intensive margin change is also statistically significant and robust to introducing controls. ${ }^{38}$ It follows that once entry, exit and merging effects are controlled for, we can obtain relatively precise estimates of the changes in the growth rate of dividend amounts along both the intensive and extensive margin. ${ }^{39}$

Panel B depicts the cumulated (from 1990-Q1) amounts of regular dividend initiations (integral of the initiation graph in Panel A) and the amounts of special dividends on the left scale. Cumulated amounts (from 1990-Q1) of regular dividend intensive changes are shown on the right scale (integral of the change in intensive margin dividends in Panel A). This figure shows that the extensive margin has contributed about $\$ 1.2$ billion to aggregate quarterly dividends since the reform. ${ }^{40}$ Total cumulated dividends from the intensive margin also surged sharply between 2002-Q4 and 2004-Q2. The graph displays a clear break in the slope in the pre and post reform periods (the quarterly slopes are given by the levels in Panel A). This figure and Table 3 show that by 2004-Q2, six quarters after the reform, $\$ 3.6$ billion in dividends have been raised from the intensive margin (subtracting out the trend in the previous years).

Finally, special dividend payments are on average $\$ 0.6$ billion per quarter higher in the post-reform quarters relative to the six pre-reform quarters (see Table 3). However, this increase is driven by a very small set of firms, as noted by Blouin et. al. (2004). More than $80 \%$ of the increase is accounted for by eight payers who made special dividend payments in excess of $\$ 100$ million in one of the quarters after the reform was enacted. ${ }^{41}$ Hence, if regular

\footnotetext{
${ }^{38}$ The t-statistic for the intensive change is substantially lower than for the initiation amount, because dividend changes along the intensive margin are much more concentrated than along the extensive margin.

${ }^{39}$ It is important to distinguish changes in levels from changes in the growth rate. As noted above, we cannot directly obtain reliable estimates of the change in the level of dividends induced by the reform. However, as Figure 12 shows, the effect of the tax reform on the growth rate of dividends is clear once compositional biases are eliminated. The importance of detrending the data is intuitive given that corporations take time to adjust their dividend policies after the change in tax regime.

${ }^{40}$ Microsoft, the largest initiator, accounted for about $20 \%$ of the total effect but the rest of initiations are not extremely concentrated, explaining the precision on the estimate in Table 3.

${ }^{41}$ More than $30 \%$ of the increase is driven by telecommunications giant Southwestern Bell Corporation, which
} 
dividend payments remain as persistent as they have historically, special dividend payments are likely to be a short-term fluctuation in the time series relative to the change in regular dividend amounts induced by the 2003 tax reform. ${ }^{42}$

The changes along the extensive and intensive margins add up to a total regular dividends increase of $\$ 4.8$ billion on average by 2004-Q2 (relative to the pre-reform trend). Starting from a base of approximately $\$ 25$ billion in 2002-Q4, total regular dividends have therefore risen by roughly $20 \%$ for our sample of non-financial, non-utility publicly traded firms. Note that the short-run increase in total dividends exceeds $20 \%$ because of the surge in special, one-time distributions. According to calculations by Poterba (2004), the average tax rate on dividends (including both taxable and non-taxable dividends distributed directly or indirectly to individuals) fell from $29 \%$ to $17 \%$, a $40 \%$ reduction. Therefore, the implied elasticity of regular dividend amounts with respect to the dividend tax rate is roughly -0.5 as of 2004-Q2, only one and a half years after the reform. ${ }^{43}$ This elasticity implies that the tax revenue from dividend taxation that was lost because of the tax cut is only $50 \%$ of the revenue loss assuming no behavioral response. ${ }^{44}$

It is interesting to note that the response to the tax change is far more rapid than that predicted by "old view" time series estimates, which imply a slow adjustment process (Poterba 2004). Since firms have chosen to increase regular (rather than special) dividend payments, which historically are rarely cut and extremely persistent, this sharp change is likely to reflect a long-term shift in payout policies that may grow even larger over time as the adjustment process continues.

\subsection{Robustness Checks}

Our identification strategy relies on the assumption that no other event apart from the tax cut generated a surge in dividend payments exactly in 2003. One possible alternative story is the exposition of several corporate scandals in 2001-2003. These scandals originated primarily

made two special dividend payments of approximately $\$ 335$ million each in 2003-Q3 and 2003-Q4.

${ }^{42}$ Of course, the $\$ 32$ billion special dividend from Microsoft in 2004-Q4 will clearly create a short-lived blip of unprecedented magnitude in the special dividend series.

${ }^{43}$ Of course, the long-run response could be even larger, given that the adjustment process may not be complete.

${ }^{44}$ However, it is possible that the increase of dividends paid out reduces other forms of taxable income such as realized capital gains from share repurchases. It is critical to assess the effect of the tax change on total tax revenue (and not only revenue from taxing dividends) in order to assess the deadweight burden of taxation (see Gordon, Kalambokidis, and Slemrod, 2003 and Saez, 2004 for a recent exposition of this point). 
from serious accounting fraud among well known corporations such as Xerox, Enron, and WorldCom, and may have created distrust among shareholders about management of large U.S. corporations in general. Shareholders may have therefore pressured management to increase dividends even in the absence of the tax cut. The timing of the surge in initiations suggests that the corporate scandals were not responsible for the surge in dividends because they were first publicized much before 2003-Q2 ${ }^{45}$ Nonetheless, we conduct three additional empirical tests to rule out this and other alternative stories about changes in unobservables.

First, and most important, we exploit the fact that only dividend income distributed to individuals through non-tax-favored accounts was affected by the reform. For instance, dividend income earned through pension funds was not affected by the tax change. Consequently, if the tax cut was responsible for the surge in aggregate dividends, we would not expect to see a response among firms who are controlled by such non-affected entities. To test this hypothesis, we first isolate a subset of institutional investors that are definitely not affected by the reform - pension funds, insurance companies, nonprofit organizations, non financial corporations, and government agencies - in the Thomson financial institutional ownership database. ${ }^{46}$ We then divide the sample of firms that are alive in our core sample in all quarters between 1998-Q1 and 2004-Q2 into two groups. ${ }^{47}$ The "control" group consists of firm-quarter pairs where the largest institutional owner is a non-affected entity. ${ }^{48}$ The "treatment" group includes all other firm-quarter pairs.

Table 4 reports the annual initiation rates among nonpayers in these two groups of firms in the pre-reform period (1998-Q1 to 2002-Q4) and the post-reform period (2003-Q1 to 2004-Q2). The initiation rate was very similar for both groups before the reform. However, the initiation

\footnotetext{
${ }^{45}$ Enron's scandal appeared in October 2001, WorldCom's in March 2002, and Tyco's in May 2002. While it is unlikely that these scandals were solely reponsible for the surge in dividends, it is possible that they magnified the extent of the response to the tax cut.

${ }^{46}$ Most large institutional shareholders (e.g., Fidelity) are partly affected by the reform, because they manage funds on behalf of taxable individuals as well as non-taxable clients such as individual retirement accounts, pensions, and nonprofits.

${ }^{47}$ Details about the definition of this sample and more general breakdowns by size of institutional ownership are given in section 5.2 below.

${ }^{48}$ Previous papers such as Perez-Gonzalez (2003) and Blouin et. al. (2004) have used companies owned by large institutional shareholders as control groups, without distinguishing non-taxable and partly taxable institutions as we do here. We find that only $15 \%$ of institutional owners (dollar weighted) are fully nontaxable. This point is particularly important because our analysis in Section 5 shows that firms with larger institutional ownership are much more responsive to the reform, implying that many institutions behave in the interests of their individual taxable clients. Therefore, raw institutional ownership is clearly not a valid proxy for nontaxable status when analyzing the effects of taxes on corporate behavior.
} 
rate surged by a factor of 5 after the reform for the treatment group, while remaining virtually constant for the control group. As a result, the post-reform initiation rates are significantly different across the two groups, and the difference-in-differences estimate of the causal effect of the tax cut is also highly statistically significant. These estimates are fully robust to a regression with controls for assets, market capitalization, profits, and industry codes, and interactions of these controls with a tax reform dummy, as in equation (3) below (with a tstatistic of 4 for the difference-in-differences). In addition, the results cannot be explained away by changing tax clienteles of shareholders: if we form the treatment and control groups using institutional ownership data from one or two quarters prior to the current quarter, the results remain very similar. ${ }^{49}$ The lack of change in the payout behavior of firms controlled by non-affected entities during the reform strongly suggests that the recent surge in dividend payments was entirely tax-driven, since there is no other obvious reason that dividend payout patterns should have diverged across these two groups at exactly the time of the reform.

Second, we use Compustat data for Canadian corporations to perform a placebo test. Canadian corporations are not affected by the tax cut unless they are owned by U.S. individuals. Although U.S. ownership of Canadian corporations is not trivial, it is likely to be small relative to U.S. ownership of U.S. corporations. ${ }^{50}$ Figure 13 plots the fraction of U.S. and Canadian firms initiating dividends in each quarter from 1994-Q1 to 2004-Q1. In sharp contrast to the United States, Canadian firms do not display a surge in dividend initiations around the 2003 reform. Therefore, if unobservable shocks such as corporate scandals affected corporate behavior in Canada as in the U.S., the evidence from Figure 13 suggests that the surge in dividends in the U.S. was indeed tax driven.

Finally, we also examine the press releases of the firms that initiated dividends after the reform was enacted and find that more than a quarter of the firms explicitly cite the tax cut as one of their motives for initiating dividends in their first announcement. This figure is likely

\footnotetext{
${ }^{49}$ Changing clienteles could potentially pose a problem because taxable institutional holders might start to purchase more shares of companies that initiated dividends after the reform because of the lower tax rate. In this case, we might find a difference in the initiations rates across our treatment and control groups even if corporate behavior was unchanged by the tax cut. The fact that pre-initiation institutional ownership predicts initiation rates in the same way rules out this hypothesis.

${ }^{50}$ Moreover, as we show in section 5 below, the tax response in the U.S. is confined primarily to firms with high executive share ownership, whose personal tax incentives changed because of the reform. Since Canadian corporations are unlikely to have top executives who are U.S. residents, we would not expect to see a tax response among these firms even if they have many diffuse U.S. based shareholders.
} 
to greatly understate the actual number of tax-motivated dividend changes because firms have strong incentives to avoid attributing their dividend decision to the tax cut, instead claiming that they are raising dividends given signs of strong future earnings. ${ }^{51}$

\section{Which Firms Responded to the Tax Change?}

In this section, we document two important forms of heterogeneity in the dividend response that shed light on the mechanism of the tax response. First, we show that the response is heavily influenced by agents' incentives and powerful principals' interests. On the agent side, firms with high executive share ownership and low executive stock-options holding were most likely to initiate dividend payments. On the principal side, firms with large share ownership among independent directors and high taxable institutional ownership responded more strongly to the tax cut. When neither the high level agents nor principals have strong incentives to push for a dividend policy change, the response to the tax cut is virtually zero. Hence, existing "old view" and "new view" models of corporate taxation in the public finance literature appear to miss a central determinant of the behavioral response to taxation by abstracting from agency problems.

Second, we provide some suggestive evidence about the efficiency effects of the tax cut. Of course, the fact that the tax cut caused a sharp surge in dividend payments does not itself imply that the efficiency of capital allocation was improved. The ideal way to estimate the efficiency effects of the tax cut would be to directly identify its effects on investment and profits. Unfortunately, this approach is infeasible because both investment and profits are very volatile, making it difficult to detect whether changes in behavior along those margins are associated with the tax cut. We provide indirect evidence of the improvement in capital allocation by showing that firms with high forecasted earnings growth did not respond to the tax cut. This suggests that funds might have been channelled away from lower growth firms toward those with better investment opportunities through external capital markets.

In addition to these cuts, we also briefly discuss heterogeneity along a large set of other dimensions, such as profits, assets, cash holdings, age, and debt levels.

\footnotetext{
${ }^{51}$ Interestingly, $13 \%$ of nonpaying companies surveyed in Brav et al. (2004) said that they would initiate dividend payments following the tax cut, a number consistent with our finding that up to 2004-Q2, about 10\% of nonpaying firms have initiated dividends.
} 


\subsection{Self-interested agents: Executive share and stock-option ownership}

A large literature in corporate finance has focused on the tension between principals' (shareholders) objectives and agents' (executives) interests. One hypothesis that has received substantial attention is that high degrees of pay-for-performance sensitivity, e.g. from large executive stock and options holdings, can have significant effects on executives' decisions about corporate policy. In this subsection, we analyze the impact of executive share and options holdings on the payout response to the tax cut.

We test for such an association without imposing strong functional form assumptions on the data, since the relevant effects could be non-linear, and outliers could be very influential. We use a semi-parametric strategy for classifying firms into quintiles based on executive share and option ownership, and compare the size of the dividend response across the quintiles. As in the preceding analysis of the overall dividend response, we must be careful to address biases that arise from changing sample composition during the dot-com boom and bust. Therefore, in this and all subsequent heterogeneity analyzes, we restrict attention to the set of 2,551 firms in the core sample that are alive between 1998-Q1 and 2004-Q2. ${ }^{52}$

Our primary data source for the share ownership and options data is ExecuComp. The shortcoming of ExecuComp data is that it covers only about one-third of the companies listed in CRSP, and these companies are not a random subsample of the CRSP firms. In particular, ExecuComp tends to cover only larger firms, which have a higher propensity to pay dividends and differ from uncovered firms along many other dimensions (e.g. large shareholder ownership) as well. To improve the precision of our estimates and obtain results that apply to the full universe of publicly traded firms, we expanded our data on share ownership by handcollecting data for an additional 347 firms from SEC proxy filings. The 347 firms include all the firms that initiated dividends, which are of greatest interest for the present study, as well as an additional 147 firms that constitute a 10\% random sample of the non-Execucomp firms that did not initiate dividends within our 1998-2004Q2 sample frame. Sampling probability weights are used to account for the under-representation of non-Execucomp non-initiating firms. The construction of the random sample is described in detail in the appendix.

\footnotetext{
${ }^{52}$ We chose a relatively long pre-reform time frame (1998-2003) in order to make the total number of dividend initiations in the pre-reform period similar to that in the post-reform period. We focus primarily on heterogeneity in dividend initiations here. Results for dividend increases are generally quite similar.
} 
We begin by analyzing the relationship between executive shareownership and dividend initiations. An executive who holds a large stake in his company experiences a large change in his personal tax burden from a dividend payment, since a considerable fraction of the total dividend payout would accrue to the executive himself. ${ }^{53}$ At the other extreme, the personal tax incentives of an executive who owns no shares are unchanged by the 2003 reform. To analyze whether the personal tax burden of executives has an impact on the tax response of corporations, we classify firms into five quintiles of executive share ownership as follows. We first identify the largest shareholder among the company's executives in a given year. We then define a stable set of quintiles using the average fraction of shares held by the largest executive shareholder during our sample frame if the firm does not initiate dividends during this period, and using share ownership as the time of initiation if the firm does initiate dividends. This procedure ensures that firms do not move across quintiles over time. The advantage of having a stable set of firms in each quintile is that it eliminates the bias that can arise if the distribution of executive share ownership changes in a manner that is correlated with dividend behavior.

Figure 14A shows the frequency of initiations among non-payers across the five quintiles of executive share ownership in the pre- and post-reform periods. The pre-reform period is defined as 1998-Q1 to 2002-Q4 and the post-reform period is 2003-Q1 to 2004-Q2. Initiations surged much more sharply in firms where at least one executive owned a substantial fraction of the company's shares. ${ }^{54}$ The post-reform annual initiation rate among firms in the highest quintile of executive share ownership is $9.5 \%$, in contrast with $3.5 \%$ in the lowest quintile. The difference between the change in the initiation rate in the fifth quintile and the first quintile is statistically significant with a p-value of 0.03 (see Appendix Table A3 for means and standard errors for each quintile, as well as the difference between the change in initiation rates between the first and fifth quintiles). The pattern for dividend increases (not reported) is also quite similar..$^{55}$

\footnotetext{
${ }^{53}$ It can be difficult for top executives in publicly traded firms to obtain cash by selling shares because share sales must be publicly reported and are likely to be interpreted as a negative signal by the market. Previous studies have found mixed results on the correlation between large executive ownership and dividend payments. Rozeff (1982) found no correlation, but a recent study by Fenn and Liang (2001) found a positive correlation. Those studies, however, do not use tax changes to identify this link.

${ }^{54}$ Both the dollar amount of shares held by the largest executive shareholder and the fraction of shares held are positively associated with the size of the tax response. The share holdings of all other executives besides the largest executive shareholder are unrelated to the tax response.

${ }^{55}$ In independent work, Nam, Wang, and Zhang (2004) and Brown, Liang, and Weisbenner (in progress), have also identified a relationship between executive ownership and dividend increases after the tax cut using
} 
In order to control for other covariates that may also influence the dividend response to the tax cut, we run a regression analogous to (2), linearly interacting each of the covariates and the five quintile dummies of interest with a tax reform dummy, $d_{T} .{ }^{56}$

$$
\text { Init }_{i, t}=\sum_{T=0}^{1}\left\{\sum_{j=1}^{5} \beta_{T, j} d_{T} * q_{\text {shrown }_{i, t}}^{j}+d_{T} * X_{i, t}\right\}+\varepsilon_{i, t}
$$

Here $T=0$ denotes the pre-reform period and $T=1$ denotes the post-reform period. The set of covariates $X$ consists of the following variables, which are averaged over the 19982004Q2 sample frame: assets, cash/assets, debt/assets, profits/assets, mktcap/assets, percent of shares held by institutions, largest executive unexercisable option holding as a percentage of total shares outstanding, and largest executive exercisable option holding as a percentage of total shares outstanding. In this regression, the $\left\{\beta_{1, j}\right\}_{j=1}^{5}$ coefficients reveal the heterogeneity in the dividend response along the executive share ownership margin, conditioning on the possible heterogeneity of responses along all the other observable margins. The estimates of the $\left\{\beta_{1, j}\right\}_{j=1}^{5}$ coefficients are reported in Appendix Table A4, along with the p-values and difference-in-difference estimates of the change in initiation rates between the first and fifth quintiles. The pattern and statistical significance of the regression coefficients is essentially unaffected by the inclusion of covariates, suggesting that executive share ownership is indeed causally associated with the dividend response to the tax cut.

Next, we examine the effect of unexercisable stock-options holdings by top executives on the tax response. Lambert, Lanen, and Larker (1989) noted that executives with large options holdings are hurt by dividend payments, because the strike prices of their options are typically not adjusted for dividends. ${ }^{57}$ By paying money out of the firm and thereby reducing the price of the shares outstanding, executives make their unexercised options less valuable. To examine whether these incentives matter for the tax response, we follow the same methodology

ExecuComp data. Our hand-collected data permits a more precise characterization of the non-linear effect of executive share ownership on the tax response, and allows us to analyze the interaction between agent and principal incentives, as discussed in section 5.3.

${ }^{56}$ Less parametric regressions with quintile dummies for all the covariates generally yield the same pattern of coefficients; however, the large number of coefficients causes the standard errors to rise relative to our more parsimonious linear specification for controls.

${ }^{57}$ More recently, Fenn and Liang (2001) and Weisbenner (2000) have shown that there is a negative relation between the number of stock options owned by management and dividend payments and a positive relation between options and share repurchases. This suggests that firms where top executives own many stock options are substituting dividends for share repurchases. Those studies, however, do not use tax changes to identify those links. 
as above and classify firms into five quintiles based on the unexercisable options holdings (as a fraction of total shares outstanding) of the executive who owns the largest number of such options.

Figure 14B shows that firms where one or more executives had a large unexercisable option holding were significantly less likely to respond to the tax cut. The annual initiation rate was $8.4 \%$ among firms whose executives were in the lowest quintile of options holdings, in contrast with $4 \%$ in the highest quintile. These differences are statistically significant with a p-value of 0.03 (Table A3). The pattern of the initiation rates is also robust to controls based on a regression specification analogous to (3) that substitutes maximum executive share ownership for unexercisable options ownership in the set of controls $X$ (Table A4). Consistent with the hypothesis that it is mainly unexercised option holdings that make dividend payments unattractive, we find a much weaker and less robust relationship between executives' exercisable options holdings and the tax response (see Tables A3 and A4).

Table 5a illustrates the interaction between executive incentives through share and option holdings by cross-tabulating the post-reform initiation rate by thirds of share ownership and unexercisable options ownership. The importance of executive incentives is striking. Only $1.6 \%$ of the firms in the lowest third of share ownership and highest third of option ownership initiated dividends in the six quarters after the reform. In contrast, $11.4 \%$ of the firms at the other extreme - highest third of share ownership and lowest third of options - have initiated dividend payments since that point. Despite the fact that the variation in share and options holdings is purely cross-sectional, it is difficult to formulate a non-agency story that would explain the share ownership, unexercisable options, and exercisable options results simultaneously. In short, there is strong evidence that executives behave in a self-interested (although not necessarily inefficient) manner when making decisions about corporate payout policy for their shareholders. ${ }^{58}$

\footnotetext{
${ }^{58}$ While the evidence of self-interested behavior is consistent with the view that corporations cannot be expected to maximize shareholder value, it does not necessarily imply that there is an inefficiency that ought to be corrected. Since executives' compensation and decision power is contracted upon with shareholders ex-ante, it is conceivable that such self-serving behavior emerges as the efficient ex-post outcome of an optimal contract that is well understood by all parties.
} 


\subsection{Powerful principals: Institutional shareholders and directors}

We now turn to the other side of the principal-agent relationship, and examine the effect of having powerful principals on the response to the tax cut. An extensive literature in corporate finance has found an association between the presence of large individual and institutional shareholders and the degree to which firms behave in value-maximizing fashion (see Shleifer and Vishny (1997) for a review). To analyze the impact of these variables on the dividend response, we quantify the power of principals in two ways: the percent of shares controlled by institutions (e.g. mutual funds, trusts, banks, etc.) and whether there is at least one independent (non-officer) director with large share holdings (over $5 \%$ of shares).

We obtain data on institutional ownership from Thompson Financial's Institutional Ownership database, which covers nearly $90 \%$ of the firms in our sample. Our primary data source for the number of large shareholders is a dataset compiled by Dlugosz et. al. (2004) which corrects a series of mistakes in Compact-Disclosure data on large shareholders compiled from firms' SEC filings. Since this dataset covers only the firms tracked by the Investor Responsibility Research Center (roughly the 1,500 largest companies in the U.S.), we augment this dataset by hand-collecting information from proxy statements for an additional set of firms. We follow the same methodology as for the executive share ownership data, collecting data for all the firms that initiated dividend payments and a $10 \%$ random sample of non-IRRC, non-initiating firms. With appropriate sampling probability weights, these additional data allow us to obtain estimates for the full universe of publicly traded firms in CRSP.

We begin by analyzing the impact of institutional ownership on the tax response. We classify firms into five quintiles based on the average fraction of shares held by institutions over the sample frame. Figure 15A shows that among firms previously not paying dividends, those with higher institutional ownership are much more likely to begin paying after the reform. The statistical significance and robustness of this conclusion to the usual set of controls (excluding institutional share ownership) used in (3) are again confirmed in Tables A3 and A4. Consistent with our results on taxable and non-taxable institutional holdings reported in section 4.6, there is no association between the fraction shares held by non-taxable institutions and the magnitude of the tax response (not reported). Only the fraction held by partially or fully taxable institutional owners matters. These findings suggest that partially 
taxable institutional owners increase their demand for dividends from the corporations in which they invest after the tax reform, and that corporations respond to these demands, perhaps because many institutions play an active role in influencing corporate boards. In addition, the fact that only taxable institutions induce a response is consistent with related studies in the corporate finance literature (reviewed in Shleifer and Vishny, 1997) showing that powerful principals are themselves self-interested, potentially acting at the expense of more diffuse minority shareholders who are less influential.

We now turn to the analysis of the impact of large-shareholding independent directors on the tax response. We classify firms into two categories: those who never had an independent large-shareholding director during the sample period, and those with at least one such director. We also cut the data into two groups by institutional ownership (below or above the sample median). Figure 15B shows that for firms with low institutional ownership, the presence of a large-shareholding independent director significantly increases the probability of initiating dividends. Table A3 shows that the director effect is significant at the $5 \%$ level without controls. Table A4 shows that the magnitude of the director effect is larger with controls, but the standard errors rise and make the difference marginally significant ( $\mathrm{p}$-value $=0.097$ ) In contrast with these results, for firms with high institutional ownership, the presence of an independent director has no effect (right side of Figure 15B). Hence, quite intuitively, powerful principals appear to substitute for each other: the presence of one powerful principal with strong incentives to demand dividends reduces the marginal impact of other powerful principals with similar interests.

Unlike directors and institutions, large "outside" (non-director) individual shareholders, have no effect on the response to the tax cut, along either the extensive or intensive margins (see Tables A3 and A4). The most likely reason for this is that dividend policy is set exclusively by the board of directors and is not typically voted upon by shareholders. Hence, large external individual shareholders may have less direct influence over the short-run payout decisions of corporations.

Table 5b illustrates the interaction between executive incentives and the power of principals. It cross-tabulates three groups ranked by top executive share ownership by three groups ranked by total institutional ownership. This table shows that executive incentives and powerful principals are also to some extent substitutes: Firms with neither executive incentives nor 
powerful principals hardly respond to the tax change, while firms with one of the two elements are 6-10 times more likely to initiate dividends in response to the tax cut. These findings show that principal-agent issues play a first-order role in determining behavioral responses to taxation, and should be included explicitly in models of optimal dividend taxation.

\subsection{Capital allocation efficiency: Forecasted earnings growth}

We now examine whether there is evidence of an efficiency improvement in capital allocation associated with the 2003 tax reform. To do so, we test for an association between forecasted growth prospects and the dividend response to the tax cut. We define forecasted growth prospects using I/B/E/S data on analysts' earnings forecasts as follows. We first compute the expected change in earnings per share as the mean earnings per share forecast for a two year forecast period minus the actual earnings per share in the current year. We then multiply this figure by the total number of shares outstanding and divide by total assets to arrive at a normalized measure of earnings growth per dollar of assets. ${ }^{59}$ Finally, we define five quintiles of earnings growth over the sample of firm-quarter pairs where the firm was not previously a dividend payer (and is therefore a candidate to initiate dividend payments).

Figure 16 shows the frequency of initiations among non-payers across the five quintiles of forecasted earnings growth in the pre- and post-reform periods. The effect of forecasted growth appears to be slightly non-linear, consistent with the hypothesis that firms that have less need for cash respond more to the tax cut. Some of the firms in quintile 1 are in distress, as their earnings are expected to fall sharply, so they respond less on average than those in quintile 2, who have more moderate earnings forecasts. Firms with the best growth prospects (quintile 5) responded very little to the tax cut. As shown in Table A3, the difference between the fifth quintile and second quintile is highly statistically significant. The general pattern of these estimates is robust to the inclusion of our standard set of covariates, as shown in Table A4, although the magnitudes of the differences are slightly attenuated and the standard errors are somewhat larger. ${ }^{60}$

\footnotetext{
${ }^{59}$ We obtain similar results when defining earnings growth as a simple percentage change in EPS; the advantage of normalizing by assets is that it permits us to include the many firms that have negative forecasted or current EPS.

${ }^{60}$ The fact that the inclusion of controls slightly weakens the effect of earnings growth on initiation rates is not surprising in view of the fact that many of our controls are highly correlated with future earnings growth (e.g. mktcap/assets, profits/assets).
} 
These results provide suggestive evidence that the dividend tax cut made the capital market reshuffle funds out of lower growth firms. ${ }^{61}$ A large set of studies have argued that free cash flow within such firms is not always put toward value-maximizing ventures because of principal-agent problems (see e.g., Jensen 1986, Rajan, Servaes, and Zingales 2000, Scharfstein and Stein 2000). Since the reduction in dividend taxes reduced executives' incentives to hoard earnings, the funds released from these lower-growth firms might have been redirected through the external capital market toward other ventures with equal or greater expected value. ${ }^{62}$

These findings are a first step toward understanding the welfare implications of dividend taxation. If the dividend tax cut had not induced payouts from lower-growth firms, it would be hard to imagine that it yielded real gains in economic efficiency. The results therefore call for further research on investment behavior to quantify the welfare benefits of the tax cut, as we discuss in the conclusion.

\subsection{Other Dimensions}

We have also examined the heterogeneity of the tax response along several other dimensions, following a quintile-classification and regression methodology analogous to that above. Some of these results are summarized in Appendix Tables A3 and A4. Unsurprisingly, we find that the tax response was stronger among firms that are in healthy, stable financial condition, i.e., those with higher levels of profits and assets and lower levels of debt. More interestingly, cash holdings are unrelated to the dividend response. This contradicts the "new view" prediction that firms with high levels of cash holdings, who presumably finance investment out of retained earnings, should not have changed payout policies after the tax cut.

\section{Substitution with Share Repurchases}

As noted in Section 2.1, it is possible for companies to leave total payout unchanged while raising dividends by reducing their share repurchases. If the tax cut simply induced firms to substitute share repurchases by dividends without raising total payout, it would be unlikely that the tax cut had large efficiency benefits because the total amount of capital recirculation

\footnotetext{
${ }^{61}$ We show in section 6 that the dividend response appears to reflect an increase in total payout, not just substitution between share repurchases and dividends.

${ }^{62}$ We cannot directly document this transfer because cash holdings fluctuate tremendously over time, making it impossible to determine whether the high growth firms obtained more funds after the reform.
} 
would remain unchanged. It is therefore very important to understand the degree to which share repurchases were crowded out by increased dividend payments.

Unfortunately, this exercise is again very difficult because of the volatility of share repurchases over time. Figure 17 illustrates the problem. Panel A depicts aggregate share repurchases (along with aggregate regular dividend payments) by firms in the core sample which have share repurchase information from Compustat from 1984-Q1 to 2004-Q1 (the most recent quarter for which Compustat data are available). The figure shows that share repurchases have exceeded dividend payments since 1997, and that they vary much more from quarter to quarter than dividends. This greater time variability makes it much harder to estimate the effects of the 2003 reform on share repurchases. ${ }^{63}$ The figure shows that share repurchases have increased substantially over the last 3 quarters but, in view of the historical record, it is clearly possible that share repurchases could have increased even more absent the tax change. Hence, it is impossible to draw any reliable conclusions about the effect of the reform on total payout (total dividends + total repurchases) in the aggregate sample.

Panel B of Figure 17 shows that looking at other moments of the total payout distribution in the full sample does not make the statistical inference problem any easier. Panel B displays the total number of firms which repurchase more than $0.1 \%$ of their shares (along with the number of firms paying regular dividends) in the core sample. The number of firms repurchasing shares is also very noisy over time, making it impossible to infer the effect of the tax cut on the total number of firms paying out in some form (either dividends or repurchases).

In order to make progress on the substitution question, we therefore focus on narrower samples where the noise in repurchases is small relative to the change in dividend behavior. From Section 5, one such sample is the set of firms with large executive share ownership, which experiences a very large surge in dividend initiations. Panel A of Figure 18 displays the fraction of regular dividend payers, the fraction repurchasing at least $0.1 \%$ of their shares, and the fraction of firms paying out in some form (either paying regular dividends or repurchasing at least $0.1 \%$ of their shares) from 2000-Q1 to 2004-Q1 for the sample of firms where a top executive owns at least $20 \%$ of the shares, which represents $12 \%$ of our sample. The fraction paying dividends in this group jumped from around $25 \%$ before the reform to over $35 \%$ by 2004 -

\footnotetext{
${ }^{63}$ Controlling for observable variables or removing the largest share repurchasers does not smooth the time series of share repurchases.
} 
Q1. Interestingly, the increase in the fraction of firms paying out (either through dividends or share repurchases) is quite similar in magnitude, from around $45 \%$ before the reform to almost $55 \%$ by 2004-Q1. The fraction of firms repurchasing shares is fairly stable over the period and falls modestly from $25 \%$ to $21 \%$ from 2002-Q3 to 2004-Q1. This graph suggests fairly convincingly that firms with large executive ownership did not simply substitute dividend payments for share repurchases after the reform, implying that the tax cut had real effects on total payout.

Unfortunately, the series of amounts paid out in the form of repurchases is too noisy to allow us to obtain a more precise estimate of the degree of substitution in amounts even for the high response group in Panel A. Panel B therefore directly examines the sample of firms that initiated dividends after the 2003 tax reform. It shows the amounts of dividends and share repurchases of this subset of firms from 2000-Q1 to 2004-Q1. ${ }^{64}$ Unsurprisingly, the amount of dividends is virtually zero before the reform and increases smoothly to almost $\$ 1$ billion by 2004-Q1. The figure also shows that, for this group, the amounts of share repurchases actually increased as well during the last 3 quarters, confirming that firms initiating dividends after the reform are not reducing their share repurchase levels relative to the pre-reform level in order to pay dividends. Furthermore, about $35 \%$ of the firms which initiated dividends after the reform never repurchased shares in 2002. In addition, among the firms initiating dividends after the reform, the fraction of firms repurchasing at least $0.1 \%$ of their shares fell only from $39 \%$ in the 2002 quarters on average to about $35 \%$ in 2004-Q1.

It should be noted that while the results from Panel B show that firms did not simply "relabel" repurchases as dividends after the reform, they do not necessarily rule out more general forms of substitution. This is because the selection of this group is endogenous (being based on the choice of initiating dividends). It is conceivable that absent the reform, the firms that initiated dividends would have repurchased more shares instead.

\section{Conclusion}

Aggregate quarterly dividend payments from publicly traded corporations surged by around $\$ 5$ billion, or $20 \%$, during the six quarters following the 2003 tax reform. Unfortunately, the time series of the level of dividend amounts is too noisy to immediately conclude that

\footnotetext{
${ }^{64}$ The figure excludes the largest initiating firm, Microsoft, in order to obtain smoother time series.
} 
this sharp increase was a systematic change associated with the dividend tax cut rather than a random event. However, the time series of dividend amounts masks several systematic, detectable changes in dividend behavior following the tax cut. The tax reform induced a large, widespread set of firms to initiate regular dividend payments or raise the payments they were already making, across all percentiles of the dividend distribution. The sharp rise in regular dividend payments along both intensive and extensive margins, both in frequencies and amounts, is unprecedented in the record of publicly traded U.S. corporations in the last three decades, and offers perhaps the clearest evidence thus far in the literature that tax policy does matter for dividend payments by large corporations. ${ }^{65}$

There is considerable heterogeneity in the dividend response, which sheds light on the mechanism through which dividend taxation affects corporate behavior. Firms with high executive share ownership and low executive stock-options holding were most likely to initiate dividend payments after the tax cut. Firms with large shareholding independent directors and high taxable institutional ownership also responded more strongly to the tax cut, while firms controlled by nontaxable institutions (who tax incentives were unchanged by the reform) did not respond. Corporations that had neither strong agent incentives (low share and high options ownership) nor large principals to induce a dividend policy change were virtually unresponsive to the tax reform. These findings show that the tax incentives of key players powerful agents and large shareholding principals - are a first-order determinant of corporate responses to taxation. In this sense, existing "old view" and "new view" models of corporate taxation in the public finance literature appear to miss an important element of the behavioral response to taxation by abstracting from agency problems. Developing a theory of dividend taxation that explicitly incorporates a principal-agent relationship could allow for a more precise assessment of the efficiency costs of dividend taxation and the optimal design of corporate and individual income tax policy.

The heterogeneity of the tax response also yields suggestive evidence about the efficiency effects of the tax cut. The tax response was concentrated among low or moderate-growth firms; firms with high forecasted earnings growth did not change payout policies in response to the tax cut. Moreover, the surge in dividend payments does not appear to have been a pure

\footnotetext{
${ }^{65}$ Since regular dividends are generally cut only in times of severe distress, it is likely that the sharp increases in dividends signal a long-term change in payout behavior.
} 
substitution for share repurchases. This suggests that funds may have been channelled away from lower growth firms toward those with better investment opportunities through external capital markets, potentially improving welfare.

Of course, in order to quantify the welfare consequences of the tax reform, it would be most interesting to analyze the effect of the reform on investment behavior directly. Unfortunately, this does not appear to be feasible because the time series of investment is extremely volatile and of much larger magnitude than dividend payments. As a result, it is impossible to estimate the effects of the tax reform on any moment of the investment distribution of publicly traded corporations with reasonable confidence intervals using the flexible, semi-parametric methods employed above. A promising avenue for future research is to study closely held corporations and compare subchapter $\mathrm{C}$ firms (which face the corporate income tax on profits) to subchapter $\mathrm{S}$ firms (which do not face the corporate tax and are unaffected by the 2003 reform). As the universe of such firms is much larger, and S-corporations offer a natural control group, estimation of other behavioral responses such as investment and debt policy might be possible. ${ }^{66}$

The sharp variations induced by the 2003 tax cut also offer the opportunity to revisit other important questions in corporate taxation beyond those addressed in this paper. One issue of particular relevance for distinguishing agency and signalling theories of dividends is the market response to dividend announcements. Bernheim and Wantz (1995) show formally and empirically that if dividends serve a signalling purpose, the market premium for increasing or initiating dividends will be larger when the tax rate is higher. Bernheim and Wantz's empirical findings have been subsequently challenged by Bernhardt, Robertson, and Farrow (1994) and Grullon and Michaely (2001), who found using different methods and data that higher tax rates were actually associated with lower dividend announcement premiums. Much of the dispute in this literature stems from the lack of sharp, credible variation in tax rates and dividend behavior. In future work, we plan to examine whether the premium for announcing dividends fell after the 2003 tax cut.

\footnotetext{
${ }^{66}$ In contrast to publicly traded corporations, closely held corporations are not required to publicly report their accounting balance sheets and dividend payments. Therefore, such a project would require using non-public corporate tax return data, available through the Treasury or the Internal Revenue Service.
} 


\section{Appendix}

\section{- Definition of Initiations and Terminations}

We define a firm as initiating dividend payments in quarter $t$ if it pays positive regular dividends in quarter $t$ and did not pay dividends in the previous four quarters $(t-1, t-2, t-3$, and $t-4$ ). If the firm pays annual dividends in quarter $t$ (or paid such an annual dividend in quarter $t-5$ or $t-6$ ), we require in addition that the firm did not pay any dividends in quarters $t-5$ and $t-6$ as well. We impose this condition to accommodate cases where annual dividend payers change the quarter in which they distribute their annual dividend payments, which can create 5 or 6 consecutive quarters with no payments but with no materially relevant interruption in regular dividend payments.

We define a firm as terminating regular dividend payments in quarter $t$ if it pays positive regular dividends in quarter $t-1$ and does not pay dividends in the next four quarters $(t, t+1$, $t+2$, and $t+3) .{ }^{67}$ Because our data is censored after quarter 2004-Q2, we do not observe the full vector of future dividend payments for observations from 2003-Q2 to 2004-Q2. To describe how we handle these cases, let $T$ denote the last quarter available in the data (2004-Q1). In those cases where $t \geq 2003-\mathrm{Q} 2$, we define a firm as terminating regular dividends if one of the following three conditions hold: (1) the firm was a quarterly payer in quarter $t-1$ and paid dividends in all quarters $t-2, t-3, t-4$, but does not pay in quarters $t$ to $T$; (2) the firm was a semi-annual payer in quarter $t-1$, but does not pay for at least two consecutive quarters starting in $t$; or (3) the firm was an annual payer in quarter $t-1$, but does not pay for at least four consecutive quarters starting in $t$. This definition of termination is the closest prediction we can obtain of actual terminations that would be observed if the data were not censored.

\section{- Definition of Intensive Increases and Decreases}

We define a firm as increasing its regular dividend payment on the intensive margin by $20 \%$ in quarter $t$ if two conditions are met: (1) the firm is not initiating payments in quarter $t$ by the definition given above; (2) regular dividends in quarter $t$ exceed regular dividends in quarter $t-1$ and quarter $t-4$ by at least $20 \% .{ }^{68}$ The definition for decreasing dividends by

\footnotetext{
${ }^{67}$ In the case of annual payers in quarter $t-1$ (or quarters $t+4$ or $t+5$ ), we impose in addition that the firm does not pay any dividends in quarters $t+4$ and $t+5$ as well, for the same reason as above.

${ }^{68}$ The requirement that dividends in quarter $t$ exceed dividends in quarter $t-4$ ensures that annual or semi-annual payers are not artificially classified as increasers every time they make a dividend payment.
} 
$20 \%$ on the intensive margin is analogous. Note that terminations are not counted as decreases to avoid double counting, given their inclusion in the extensive analysis. Every firm is assigned a value of 0 for both the increase and decrease dummy variables in their first four quarters in the sample, since there is inadequate historical information to apply our definition in these cases. Firms not paying or initiating dividends in period $t$ are always assigned a value of 0 for both dummy variables.

\section{- Supplementary data collected from SEC proxy filings}

We collected data on executive stock and option ownership following the definitions in Execucomp and large blockholder ownership (>5\%) following the definitions in Dlugosz, Fahlenbrach, Gompers, and Metrick (2004) for 347 additional firms not covered in these datasets. These firms included 200 firms that initiated dividends between 1998-Q1 and 2004-Q2, for whom we collected proxy data in the year of initiation. The remaining 147 firms are a random sample of the non-initiating firms not covered by one of Execucomp or Dlugosz et. al. We obtained this sample by randomly drawing the name of $10 \%$ of the firms (163 firms) in this subset, along with a random date between 1998-Q1 and 2004-Q2 for which we collected proxy data. In constructing the random sample of dates, we required that fifty percent of the dates were chosen in the post-reform period (after 2003-Q1) given the importance of precision in the post-reform period. We were unable to obtain proxy statements for 16 of the 163 firms in our random sample, giving us an ultimate random sample size of 147 . The under-representation of firms in the non-Execucomp, non-Dlugosz, non-initiating group is corrected for in our heterogeneity analysis by probability weighting these observations by the sampling probability, so that they receive more weight in all computations. 


\section{References}

Allen, Franklin and Roni Michaely, 2003, "Payout Policy," in Constantinides, George, Milton Harris and Rene Stulz eds. Handbook of the Economics of Finance (Amsterdam: NorthHolland)

Auerbach, Alan, 1979, "Wealth maximization and the cost of capital," Quarterly Journal of Economics 93, 433-46.

Auerbach, Alan, 2003, "Taxation and Corporate Financial Policy," in Auerbach, Alan and Martin Feldstein eds. Handbook of Public Economics, Volume 3, (Amsterdam: North-Holland)

Auerbach, Alan and Kevin Hassett, 2003, "On the Marginal Source of Investment Funds," Journal of Public Economics 87(1), 205-232.

Auerbach, Alan and Kevin Hassett, 2004, "The Effects of the 2003 Dividend Tax Cut on Stock Prices: An Event Study," unpublished working paper, University of California at Berkeley.

Baker, Malcolm, and Jeffrey Wurgler (2004a), "Appearing and Disappearing Dividends: The Link to Catering Incentives." Journal of Financial Economics 73(2), 271-288.

Baker, Malcolm, and Jeffrey Wurgler (2004b), "A Catering Theory of Dividends." Journal of Finance 59(3), 1125-1165.

Bernhardt, Dan, J. Fiona Robertson and Ray Farrow, 1994, "Testing Dividend Signaling Models," Working Paper, Queen's University.

Bernheim, Douglas and Adam Wantz (1995), "A Tax-Based Test of the Dividend Signalling Hypothesis", American Economic Review 85(3), 532-551.

Blouin, Jennifer, Jana Raedy, and Douglas Shackelford (2004), "Did Dividends Increase Immediately after the 2003 Reduction in Tax Rates", NBER Working Paper No. 10301

Bolster, Paul J. and Vahan Janjigian (1991), "Dividend Policy and Valuation Effects of the Tax Reform Act of 1986", National Tax Journal 44(4), 511-518.

Bradford, David F., 1981, "The incidence and allocation effects of a tax on corporate distributions," Journal of Public Economics 15, 1-22.

Brav, Alon, John R. Graham, Campbell R. Harvey, and Roni Michaely (2004), "Payout policy in the 21st century", forthcoming Journal of Financial Economics.

Chetty, Raj and Emmanuel Saez (2004), "Do Dividend Payments Respond to Taxes? Preliminary Evidence from the 2003 Dividend Tax Cut", NBER Working Paper No. 10572.

Cummins, Jason, Kevin A. Hassett, and R. Glenn Hubbard (1994), "A Reconsideration of Investment Behavior using Tax Reforms as Natural Experiments", Brookings Papers on Economic Activity 25, 1-59.

DeAngelo, Harry, and Linda DeAngelo, 1990, "Dividend policy and financial distress: An empirical examination of troubled NYSE firms," Journal of Finance, 45, 1415-1431.

DeAngelo, Harry, Linda DeAngelo, and Doug Skinner, 2000, "Special Dividends and the Evolution of Dividend Signaling," Journal of Financial Economics, pp. 309-354.

DeAngelo, Harry, Linda DeAngelo, and Doug Skinner, 2003, "Are dividends disappearing? Dividend concentration and the consolidation of earnings." Journal of Financial Economics, 
forthcoming.

Desai, Mihir and Goolsbee, Austan (2004), "Investment, Capital Overhang and Fiscal Policy", forthcoming Brookings Papers on Economic Activity.

Dlugosz, Jennifer, Rudiger Fahlenbrach, Paul Gompers, and Andrew Metrick, (2004), "Large Blocks of Stock: Prevalence, Size, and Measurement", Wharton Business School Working Paper.

Fama, Eugene and Kenneth French, 2001, "Disappearing dividends: Changing firm characteristics or lower propensity to pay", Journal of Financial Economics 60, 3-43.

Feldstein, Martin, (1970) "Corporate taxation and Dividend Behavior," Review of Economic Studies 37, 57-72.

Fenn, George W. and Nellie Liang, 2001, "Corporate payout policy and managerial stock incentives", em Journal of Financial Economics, 60(1), 45-72.

Goolsbee, Austan (1998), "Taxes, organizational form, and the deadweight loss of the corporate income tax", Journal of Public Economics 69(1), 143-152.

Goolsbee, Austan (2004), "The Impact and Inefficiency of the Coporate Income Tax: Evidence from State Organizational Form Data,", Journal of Public Economics 88(11), 2283-2299.

Gordon, Roger H., Laura Kalambokidis, and Joel Slemrod, (2003) "Do We Now Collect Any Revenue From Taxing Capital Income?," forthcoming Journal of Public Economics.

Gordon, Roger H. and Young Lee (2001), "Do taxes affect corporate debt policy? Evidence from U.S. corporate tax return data" Journal of Public Economics 82(2), 195-224.

Gordon, Roger H., and Jeffrey MacKie-Mason (1990), "Effects of the Tax Reform Act of 1986 on Corporate Financial Policy and Organizational Form", in J. Slemrod, ed., Do Taxes Matter? The Impact of the Tax Reform Act of 1986 (MIT Press: Cambridge), 91-131.

Grullon, Gustavo and Roni Michaely, 2001, "Asymmetric information, agency conflicts and the impact of taxation on the market reaction to dividend changes," Working paper, Cornell University, Ithaca NY.

Grullon, Gustavo and Roni Michaely, (2002) "Dividends, Share Repurchases, and the Substitution Hypothesis", Journal of Finance, 57(4), 1649-1684.

Jensen, Michael C, 1986, "Agency costs of free cash flow, corporate finance and takeovers," American Economic Review 76, 323-329.

Julio, Brandon, and David Ikenberry (2004) "Reappearing Dividends", Working Paper College of Business, University of Illinois.

King, Mervin A., 1977, Public Policy and the Corporation, (Chapman and Hall, London).

Lambert, Richard, William Lanen and David Larcker, 1989, "Executive stock option plans and corporate dividend policy," Journal of Financial and Quantitative Analysis 24, 409- 425.

LaPorta, Rafael, Florencio Lopez-de-Silanes, Andrei Shleifer, and Robert Vishny, 2000, "Agency problems and dividend policies around the world," Journal of Finance 55(1), 1-33.

Lintner, J., 1956. "Distribution of incomes of corporations among dividends, retained earnings, and taxes," American Economic Review 46, 97-113. 
Nam, Jouahn, Jun Wang, and Ge Zhang (2004), "The Impact of Dividend Tax Cut and Managerial Stock Holdings on Firm's Dividend Policy", unpublished mimeograph, Baruch College.

Perez-Gonzalez, Francisco, 2003, "Large shareholders and dividends: Evidence from U.S. tax reforms", Working paper, Columbia University.

Poterba, James, 2004, "Corporate Payout Policy", American Economic Review, 94(2), 171175 .

Poterba, James and Lawrence Summers, 1985 "The Economic Effects of Dividend Taxation", in E. Altman and M. Subrahmanyam, eds., Recent Advances in Corporation Finance (Homewood, IL: Dow Jones-Irwin), 227-284.

Rajan, Raghuram, Henri Servaes, and Luigi Zingales, 2000, "The cost of diversity; The diversification discount and inefficient investment," Journal of Finance 55, 35-80.

Rozeff, Michael S., 1982, "Growth, beta, and agency costs as determinants of dividend payout ratios", Journal of Financial Research 5, 249-259.

Saez, Emmanuel (2004). "Reported Incomes and Marginal Tax Rates, 1960-2000: Evidence and Policy Implications." in ed. J. Poterba, Tax Policy and the Economy (MIT Press: Cambridge), 18, 117-173.

Scharfstein, David and Jeremy Stein, 2000, "The Dark Side of Internal Capital Markets: Divisional Rent-Seeking and Inefficient Investment," Journal of Finance 55 (6).

Shleifer, Andrei and Robert Vishny, "A Survey of Corporate Governance," Nobel Symposium on Law and Finance, August, 1995, Journal of Finance, June 1997.

U.S. Treasury Department, Internal Revenue Service (2003) "Statistics of Income: Individual Income Tax Returns 2000", U.S. Government Printing Office, Washington D.C.

Weisbenner, Scott (2000), "Corporate Share Repurchases in the 1990s: What Role Do Stock Options Play?" Federal Reserve Board Working Paper. 
Figure 1

Total Regular and Special Dividends and Top Dividend Payers

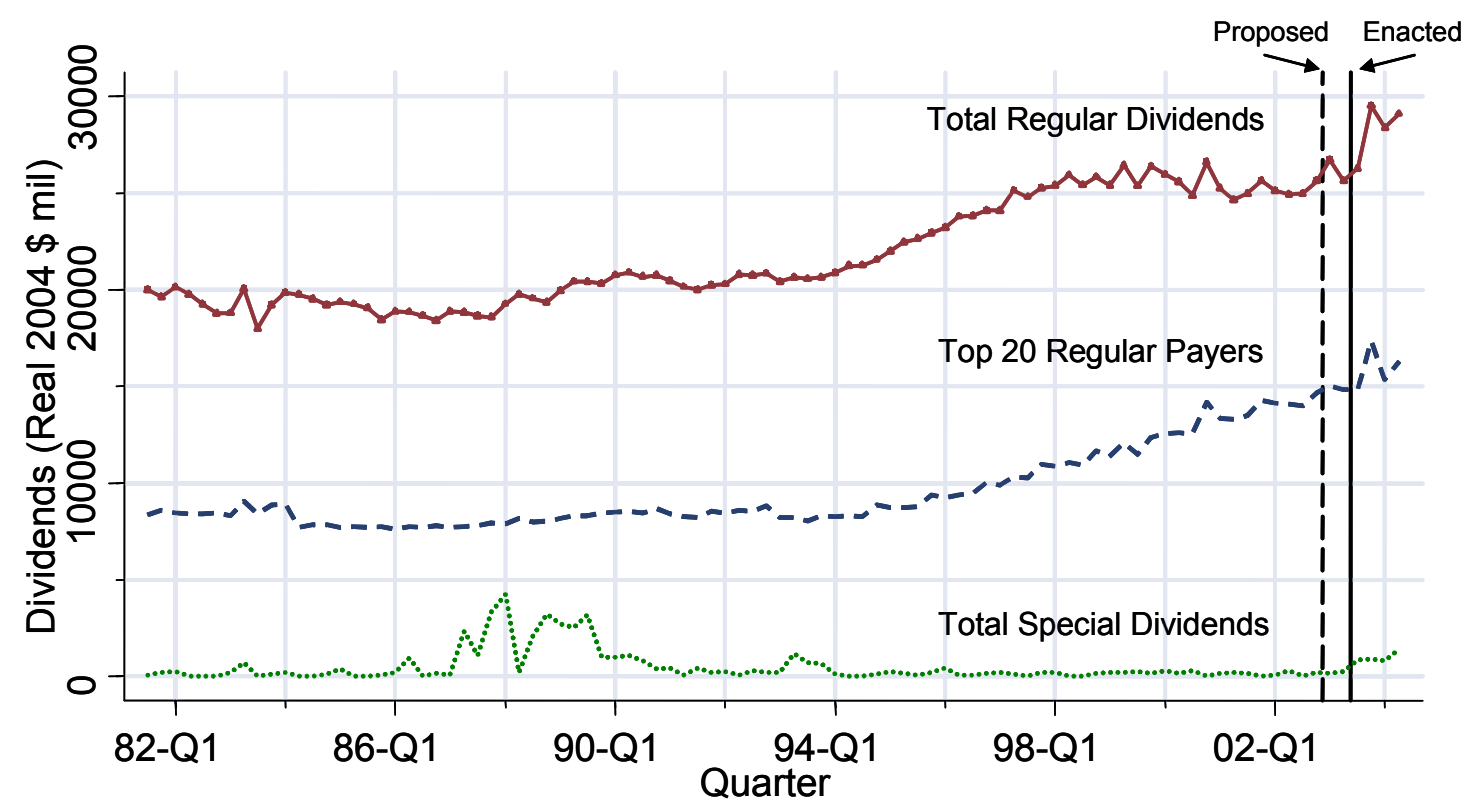

This figure depicts aggregate regular dividend payments, aggregate special dividend payments, and total regular dividend payments made by the largest 20 regular dividend payers for each quarter from 1981-Q3 to 2004-Q2. The sample consists of all firm-quarters in the CRSP database that are non financial, non utility, and non foreign in their last quarter (the "core" sample). Regular dividends are defined as monthly, quarterly, semi-annual, annual taxable dividends. Regular dividends also include other and unknown frequency taxable dividends that are followed by regular payments (see text). Special dividends are defined as special and all remaining other and unknown frequency taxable dividends listed in CRSP. The solid vertical line (separating quarters 2003-Q2 and 2003-Q3) denotes the time at which the 2003 tax reform was enacted (end of May 2003). The dashed vertical line (separating quarters 2002-Q4 and 2003-Q1) denotes the time at which the lower tax rate on dividend income was proposed and started (retrospectively) to apply. 


\section{Figure 2}

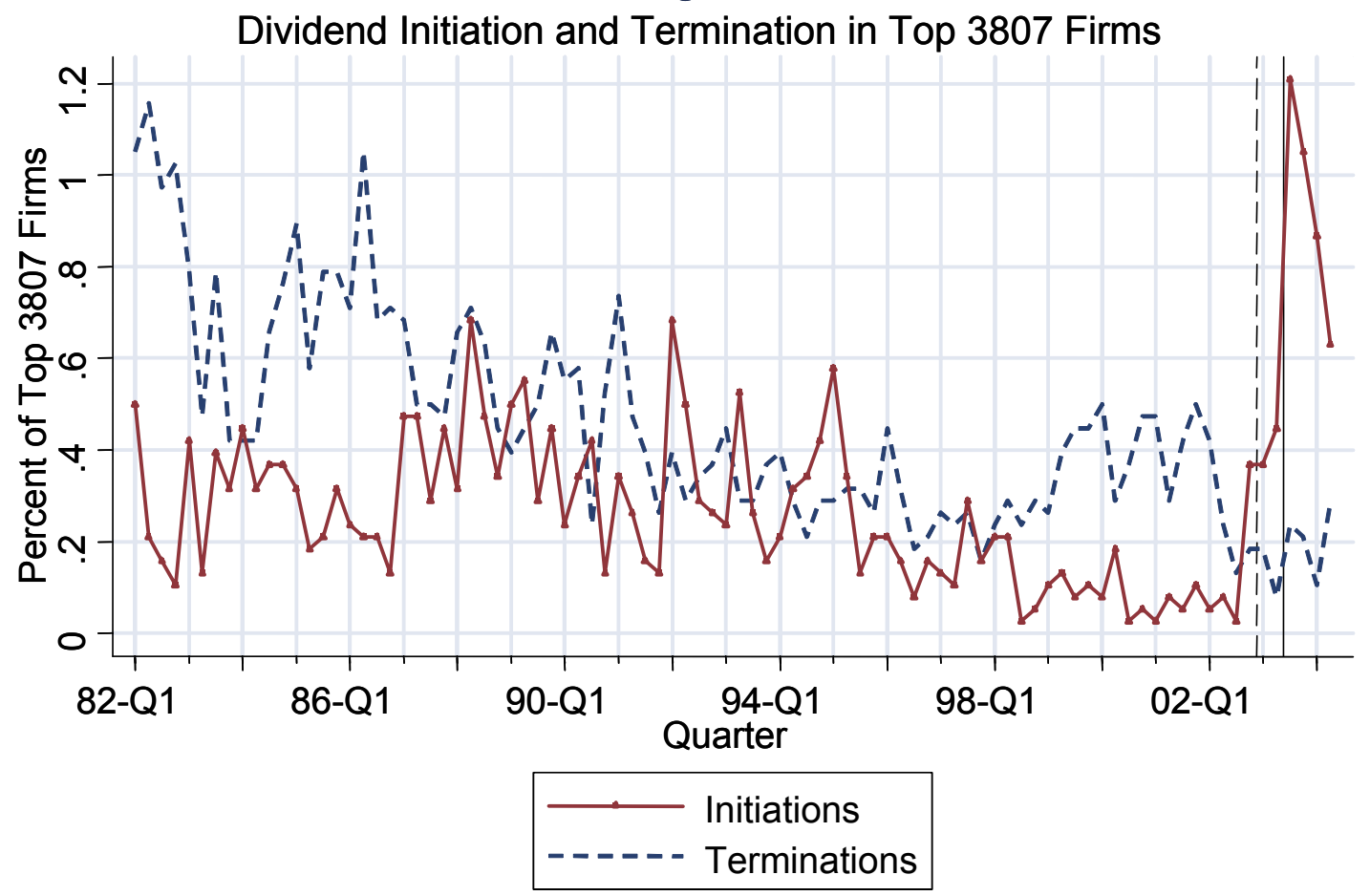

This figure depicts the fraction of firms initiating and terminating regular dividend payments for each quarter from 1984-Q1 to 2004-Q2. The data sample consists, in each quarter, of the top 3,807 firms (ranked by market capitalization in each quarter) in the CRSP database which are non financial, non utility, and non foreign in their last quarter (constant number of firms sample). Initiation is defined as starting to pay regular dividends after having been in the sample and not paying regular dividends for at least four quarters. Termination is defined as stopping to pay regular dividend payments for at least four quarters. Skipping a dividend payment is not considered a termination (see text for complete details). 


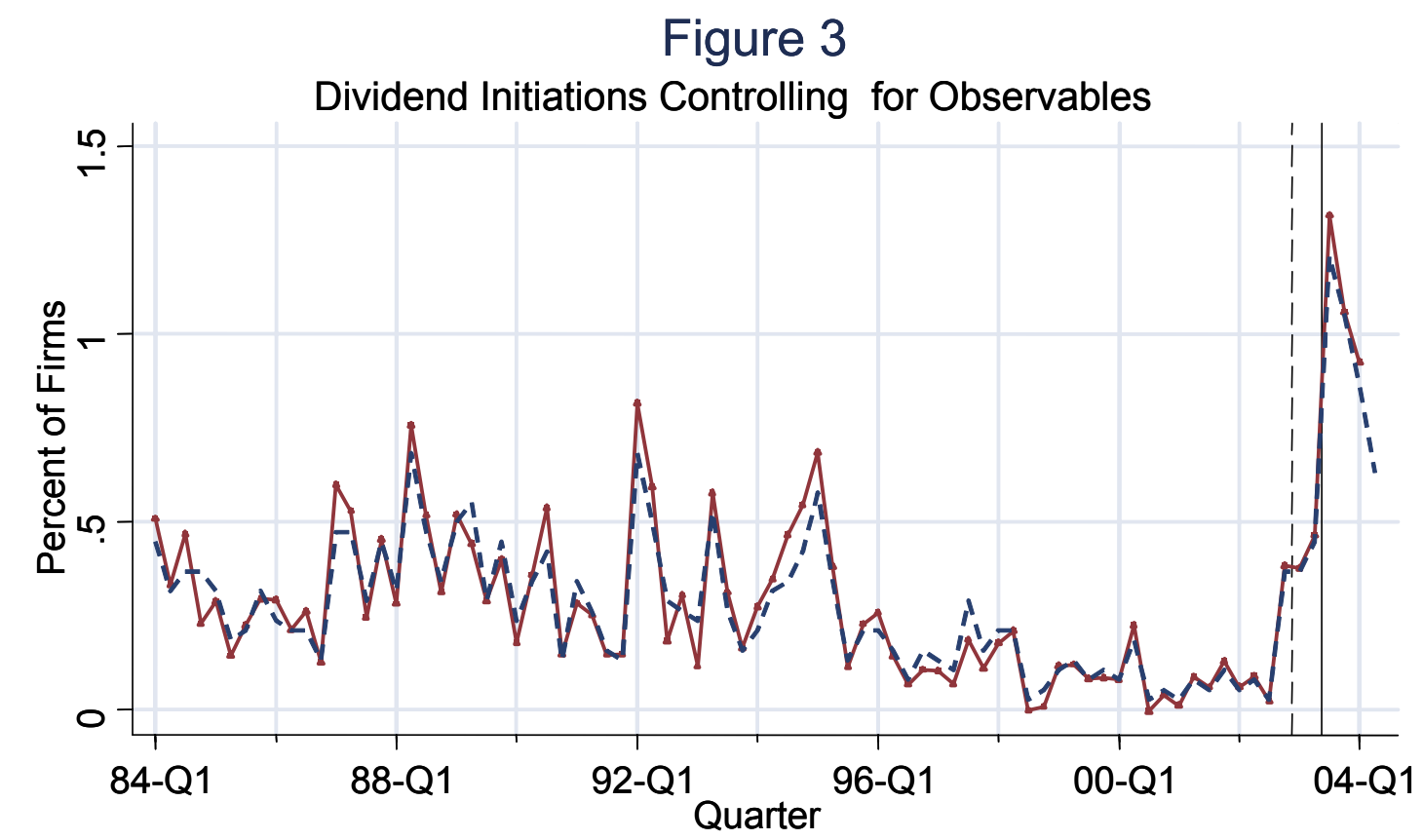

\begin{tabular}{l} 
_- Percent Initiations: regression residuals, top 3807 sample \\
\hline$-1-$ - Percent Initiations: means, top 3807 sample
\end{tabular}

This figure depicts the fraction of firms initiating dividend payments with and without control variables for each quarter from 1984-Q1 to 2003-Q4 . In the case with no controls, the data sample consists as in Figure 2 of the firms in the constant number of firms sample. The no-controls curve reports the fraction of those firms initiating dividend payments. In the case with controls, the data sample is same with the additional requirement that variables assets, after-tax profits, cash from Compustat are available. The regression residuals curve reports the quarter dummy coefficients of an OLS regression of the initiation dummy on a full set of quarter dummies, dummies for first digit industry code, assets, and levels and eight quarterly lags of after-tax profits/assets, marketcap/assets, and cash/assets (see specification (2) in text). 


\section{Figure 4}

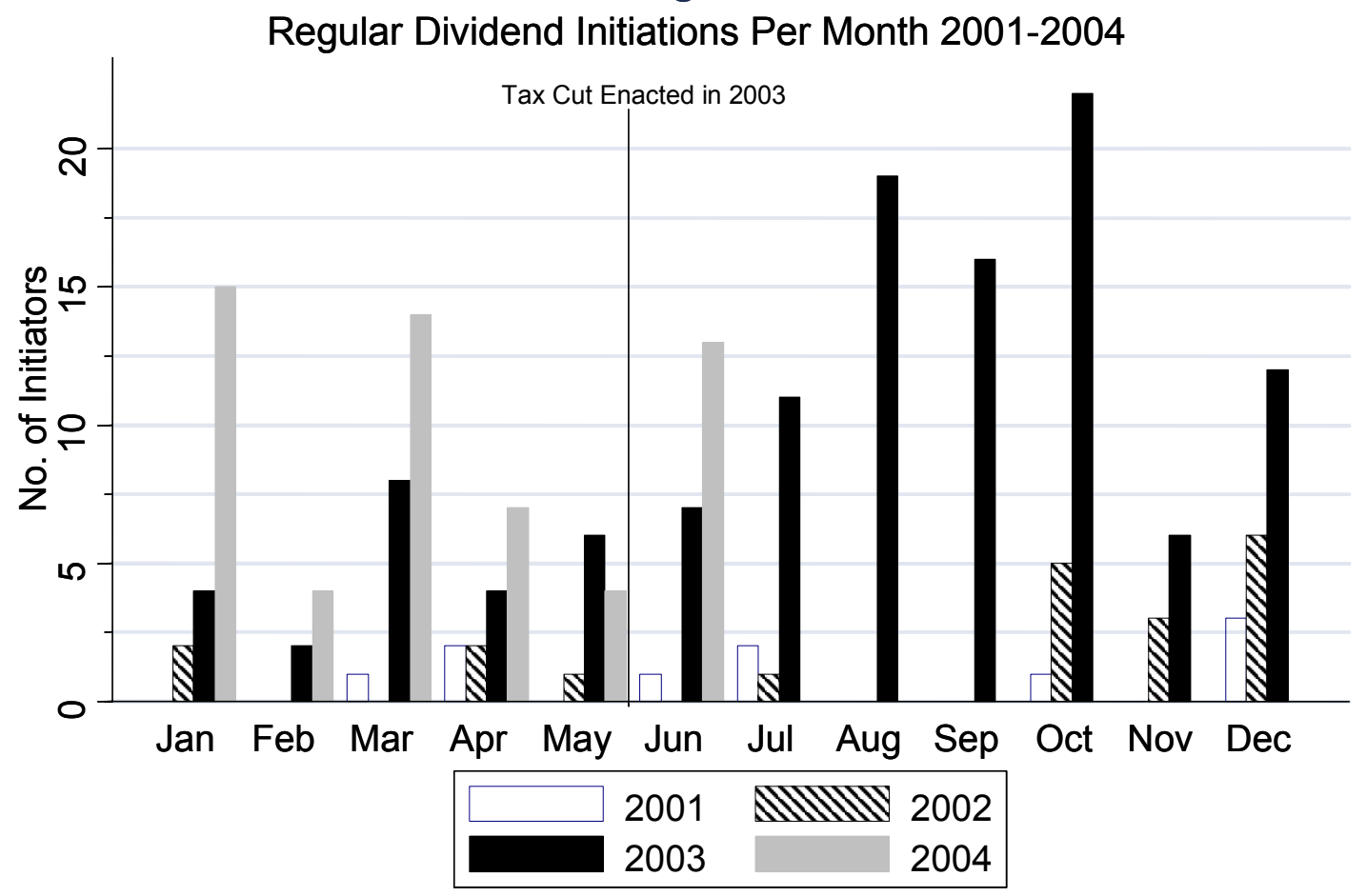

This figure depicts the number of firms initiating dividend payments for each month from January 2001 to June 2004. The data sample consists as in Figure 2, in each month, of the top 3,807 firms (ranked by market capitalization in each corresponding quarter) in the CRSP database which are non financial, non utility, and non foreign in their last quarter (constant number of firms sample). Initiation is defined as starting to pay regular dividends after having been in the sample and not paying regular dividends for at least four quarters (see text for complete details). 


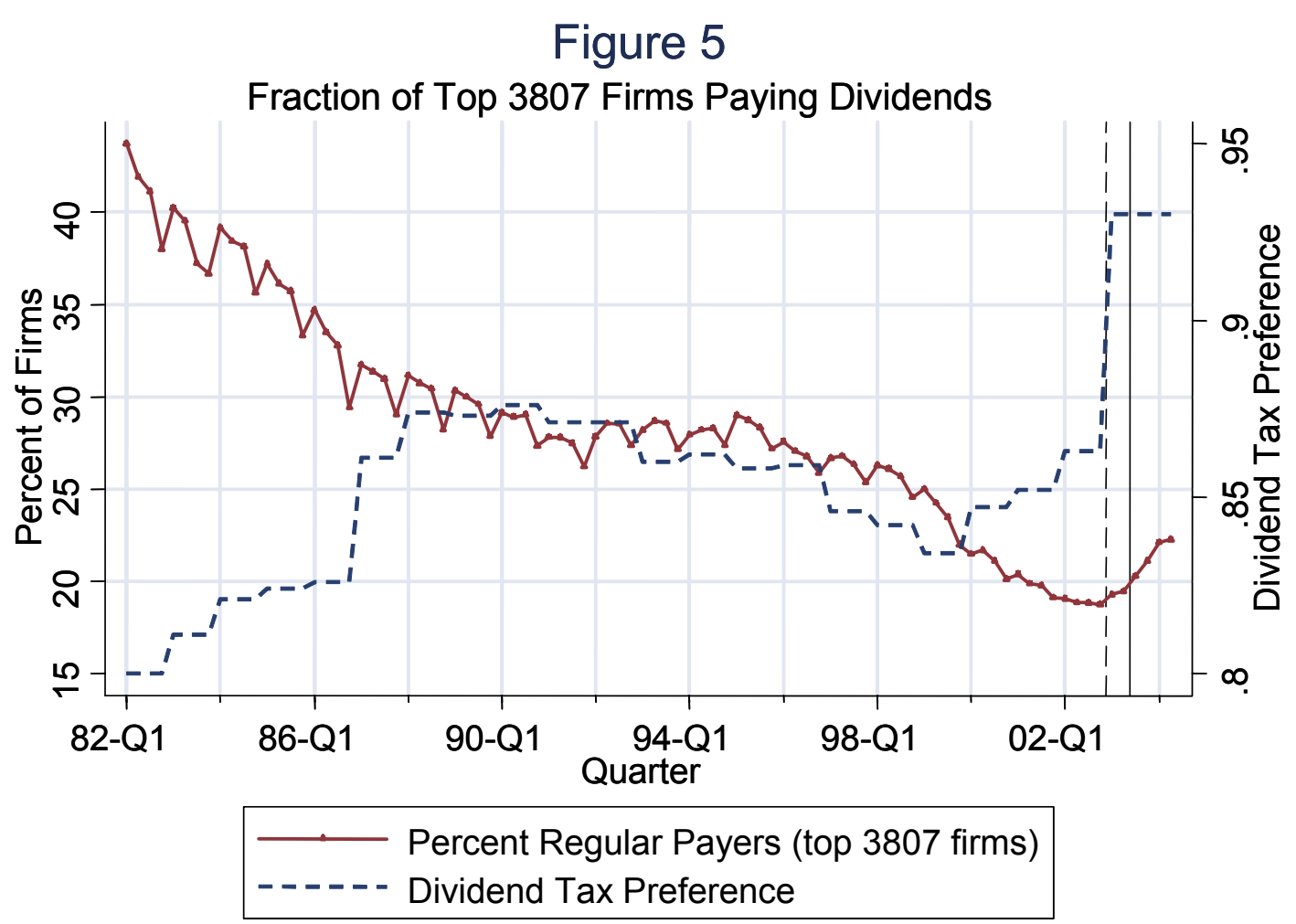

This figure depicts the fraction of firms paying regular dividend payments for each quarter from 1984-Q1 to 2004-Q2 (with scale on the left vertical axis). The data sample consists, in each quarter, of the top 3,807 firms (ranked by market capitalization in each quarter) in the CRSP database which are non financial, non utility, and non foreign in their last quarter (constant number of firms sample). Regular dividends are defined as monthly, quarterly, semi-annual, annual taxable dividends. Regular dividends also include other and unknown frequency taxable dividends which are followed by regular payments (see text). The figure also depicts (with scale on the right vertical axis) the dividend tax preference parameter from Poterba (2004). This parameter is defined as the dollar weighted average across all investors (individuals and institutional) of $\left(1-\tau_{d i v}\right) /\left(1-\tau_{c g}\right)$ where $\tau_{\text {div }}$ is the marginal tax rate on dividend income and $\tau_{c g}$ the average marginal tax rate on capital gains in the U.S. economy. 


\section{Figure 6a}

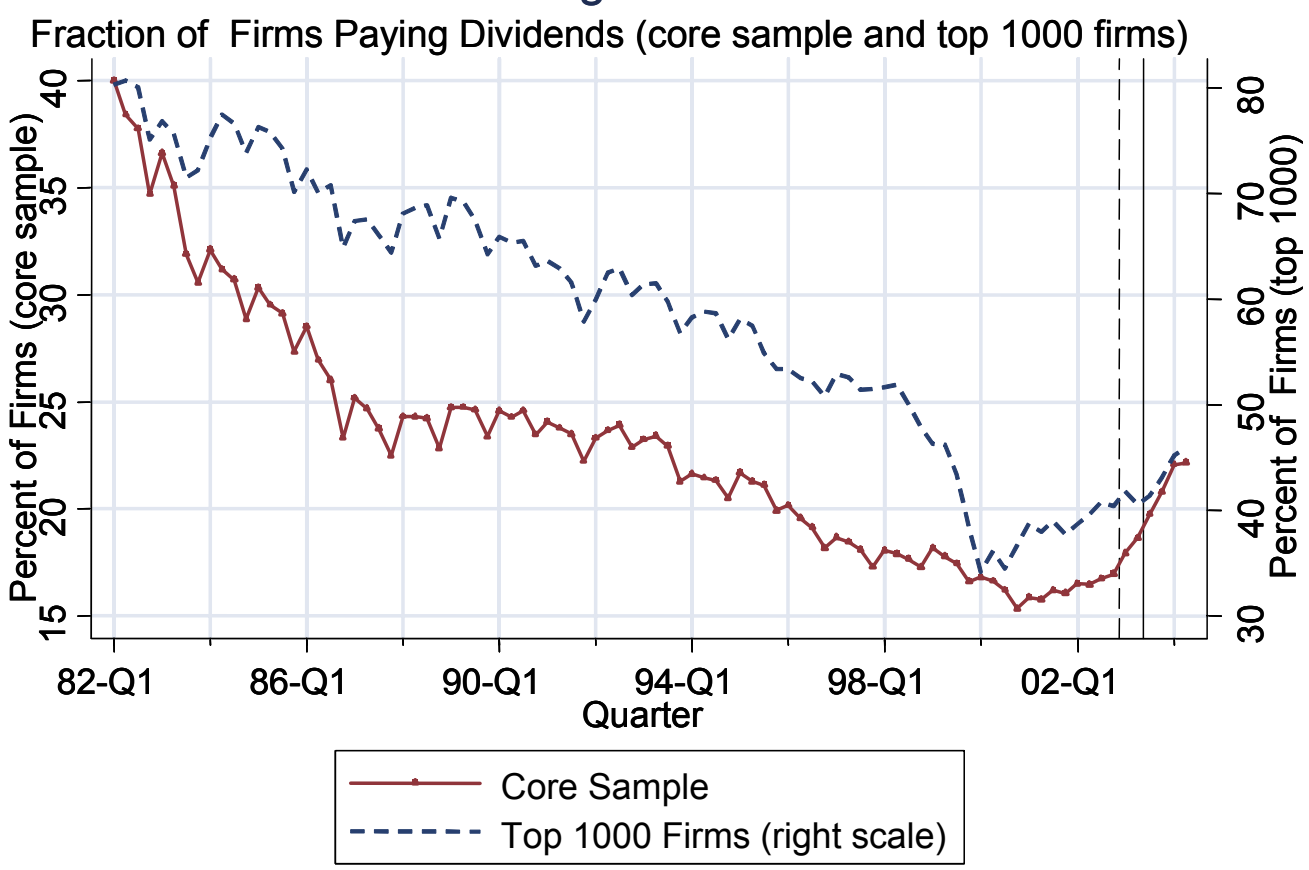

Figure $6 b$

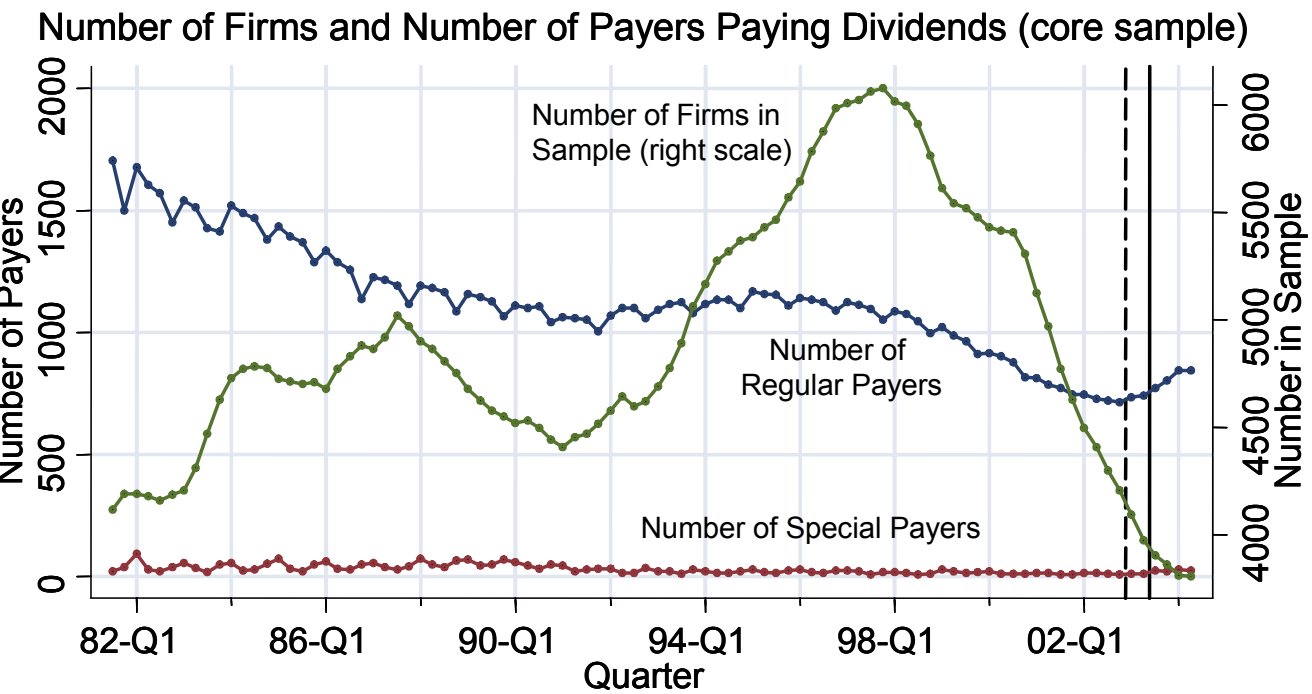

Panel A depicts the fraction of firms paying regular dividend payments for each quarter from 1982Q1 to 2004-Q2. In the first curve, the sample consists, in each quarter, of all firms in the CRSP database which are non financial, non utility, and non foreign in their last quarter (core sample). In the second curve, the sample of firms is limited to the top 1,000 firms ranked in each quarter by market capitalization. Regular dividends are defined as in Figure 1.

Panel B depicts the total number of firms (right scale) and the number of regular dividend payers and special dividend payers (left scale) for each quarter from 1982-Q1 to 2004-Q2. For all three curves, the data sample consists, in each quarter, of all firms in the core sample. 


\section{Figure 7}

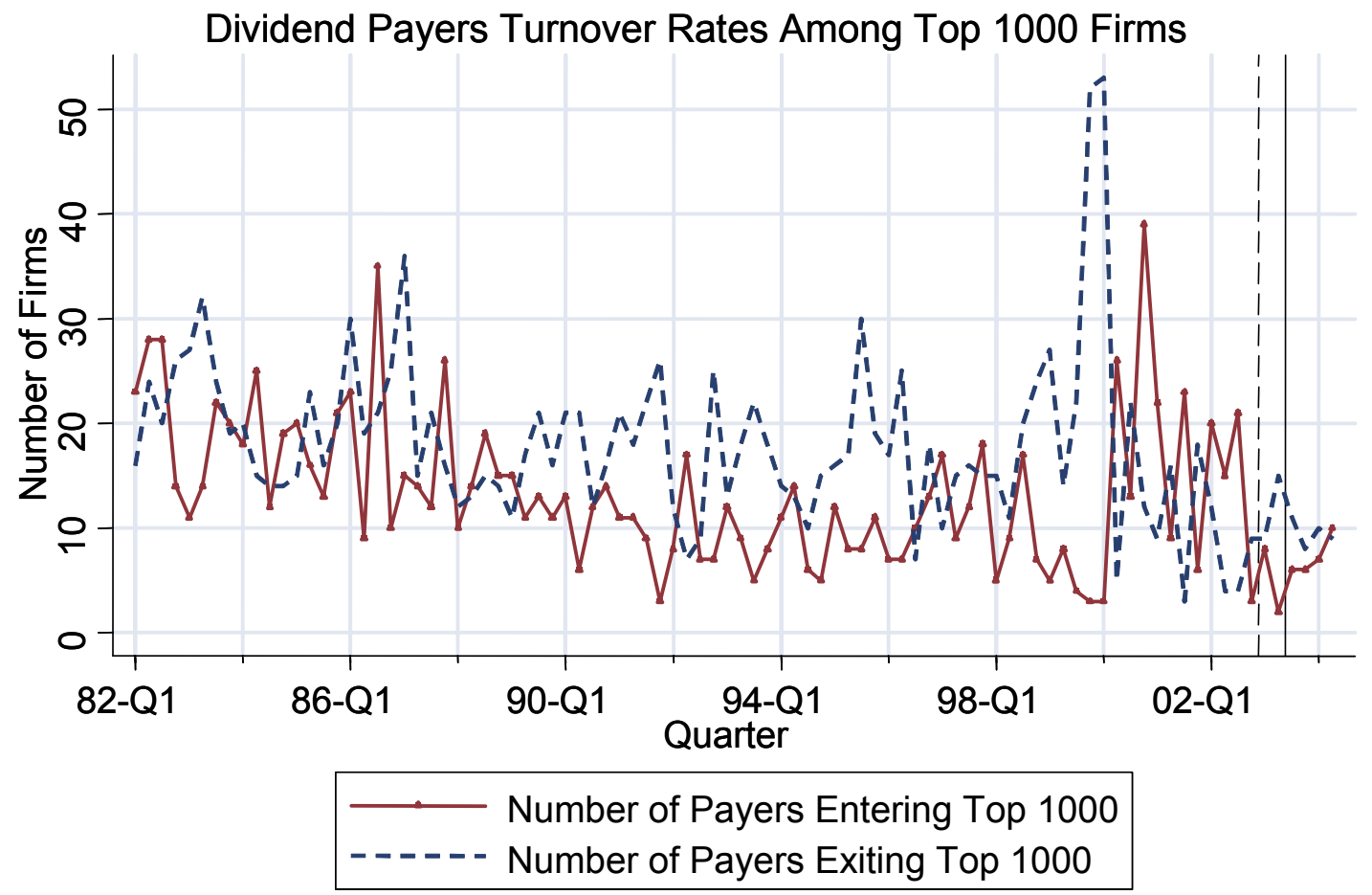

The sample consists, in each quarter, of the top 1,000 firms (ranked by market capitalization in each quarter) in the CRSP database which are non financial, non utility, and non foreign in their last quarter. The first curve depicts the number of regular dividend payers that entered the sample of the top 1,000 firms in quarter $t$. The second depicts the number of regular dividend payers that exited the sample of the top 1,000 firms in quarter $t$. 
Figure 8a

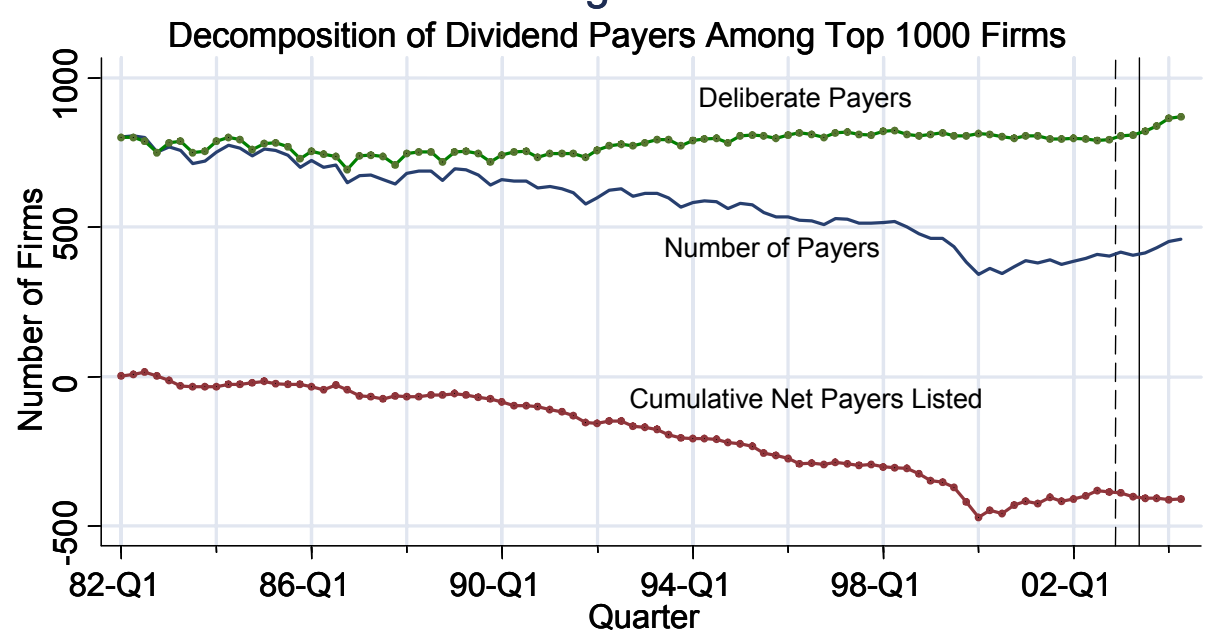

Figure 8b

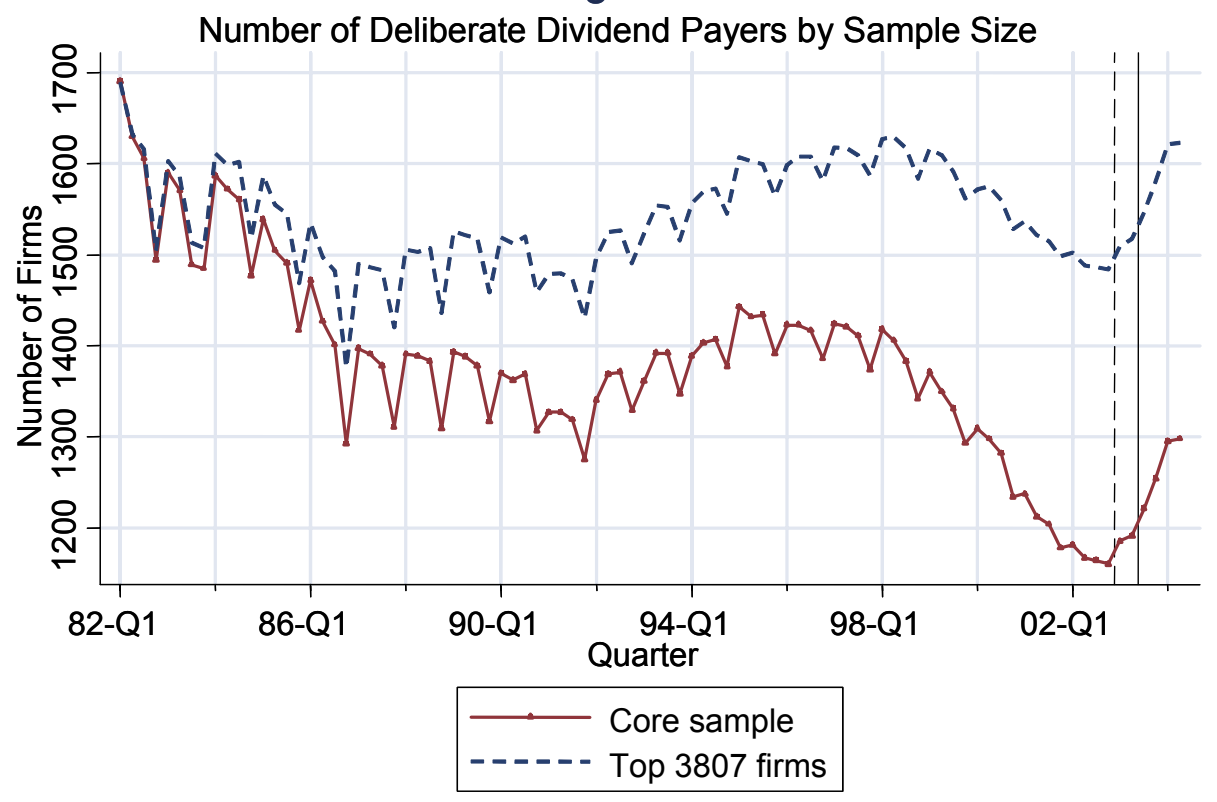

In Panel A, the sample consists, in each quarter, of the top 1,000 firms (ranked by market capitalization in each quarter) in the CRSP database which are non financial, non utility, and non foreign in their last quarter. The first curve depicts the number of the top 1,000 firms paying regular dividends. The second depicts, the cumulative difference (from 1982-Q1) between the number of regular dividend payers who entered the top 1,000 firms and the number of regular dividend payers who left the top 1,000 firms. The third curve is the difference between the first two, and captures the number of "deliberate" payers among the top 1,000 firms controlling for entry and exit effects.

Panel B plots the third (deliberate payers) curve in Panel A for the core sample (all non utility, non financial, non foreign CRSP firms) and the constant number of firms sample (top 3,807 firms in each quarter ranked by market capitalization). These two graphs capture the evolution of the number of dividend payers firms controlling for entry and exits effects in these two samples. 
Figure 9a

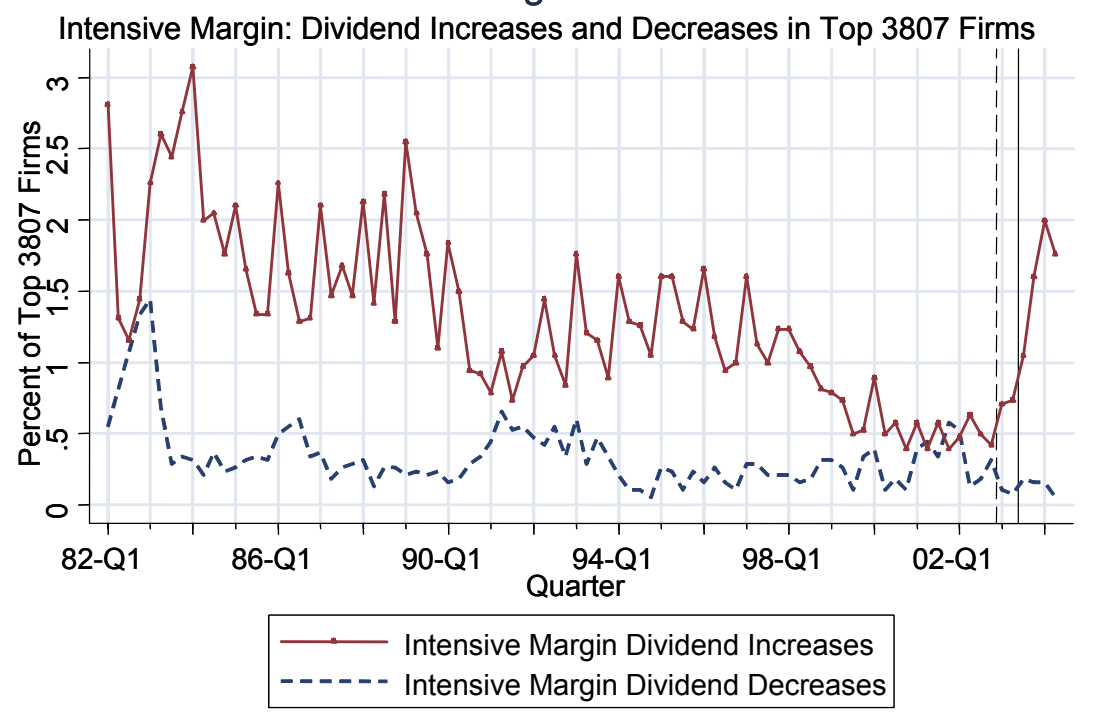

Figure 9b

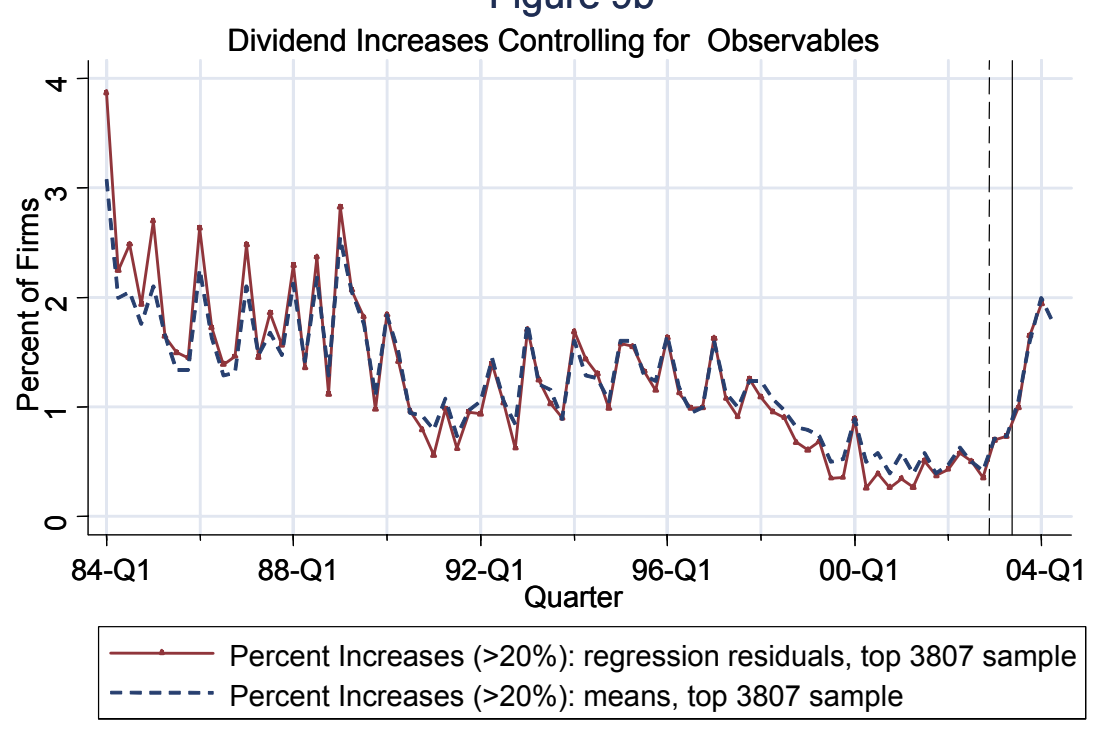

Panel A depicts the fraction of firms increasing and decreasing regular dividend payments by more than $20 \%$ in a given quarter in the constant number of firms sample. An increase in dividend payments by $20 \%$ in quarter $t$ occurs when the firm (1) does not initiate dividend payments in quarter $t,(2)$ pays dividends in quarter $t$ larger in real terms by $20 \%$ than dividends paid in quarters $t-1$ and $t-4$. Decreases in dividends payments are defined in an analogous way. (see text for further details).

Panel B depicts the fraction of firms increasing dividend payments in the core sample without controls (as in Panel A), and the corresponding curve controlling for covariates. In the case with controls, the sample is the set of firms that satisfy the additional requirement that assets, post-tax profits, market to book ratios, and cash from Compustat are available. The regression residuals curve reports the quarter dummy coefficients of an OLS regression of the $>20 \%$ increase dummy on a full set of quarter dummies, dummies for first digit industry code, assets, and levels and eight quarterly lags of after-tax profits/assets, marketcap/assets, and cash/assets (see specification (2) in text). 
Figure 10

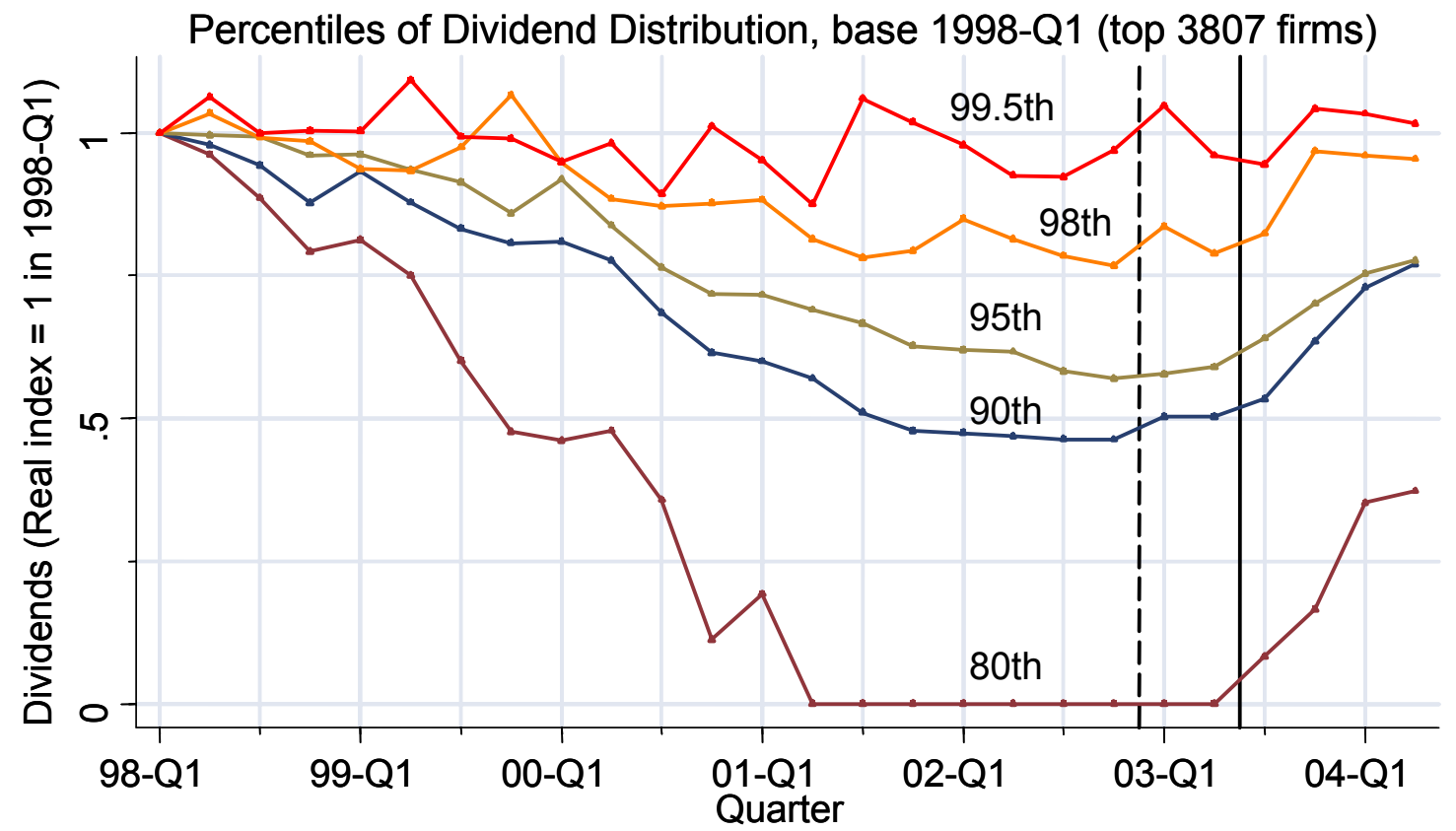

This figure depicts various percentiles of the regular dividend distribution at each quarter from 1998-Q1 to 2004-Q2. The zeros (non dividend payers) are included in the distribution. The percentiles are normalized so that they are all equal to one in 1998-Q1. The sample consists, in each quarter, of the top 3,807 firms (ranked by market capitalization in each quarter) in the CRSP database which are non financial, non utility, and non foreign in their last quarter (constant number of firms sample). 


\section{Figure 11}

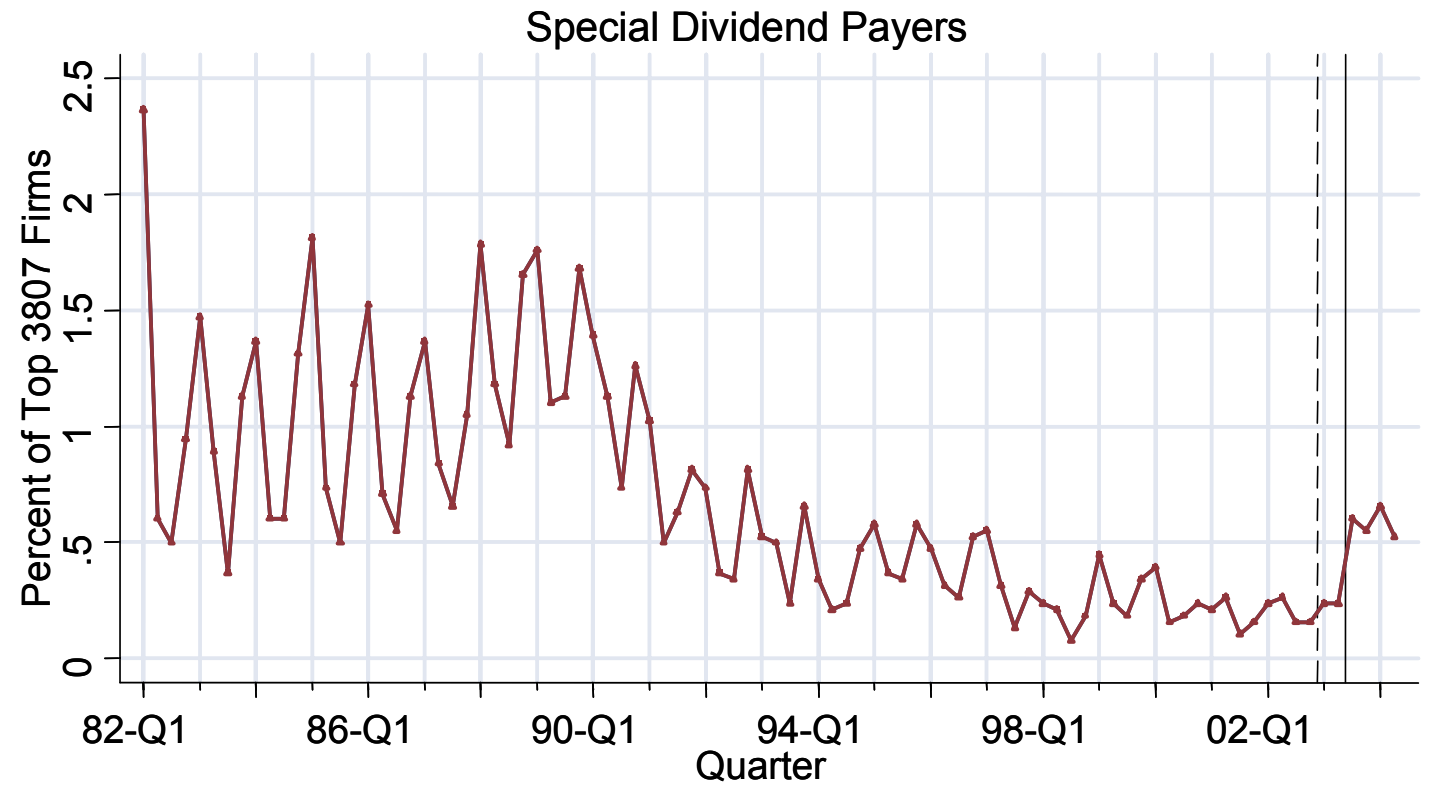

This figure shows the fraction of firms paying special dividends. Special dividends are defined as special and all remaining other and unknown frequency taxable dividends listed in CRSP. The sample consists, in each quarter, of the top 3,807 firms (ranked by market capitalization in each quarter) in the CRSP database which are non financial, non utility, and non foreign in their last quarter (constant number of firms sample). 
Figure $12 \mathrm{a}$
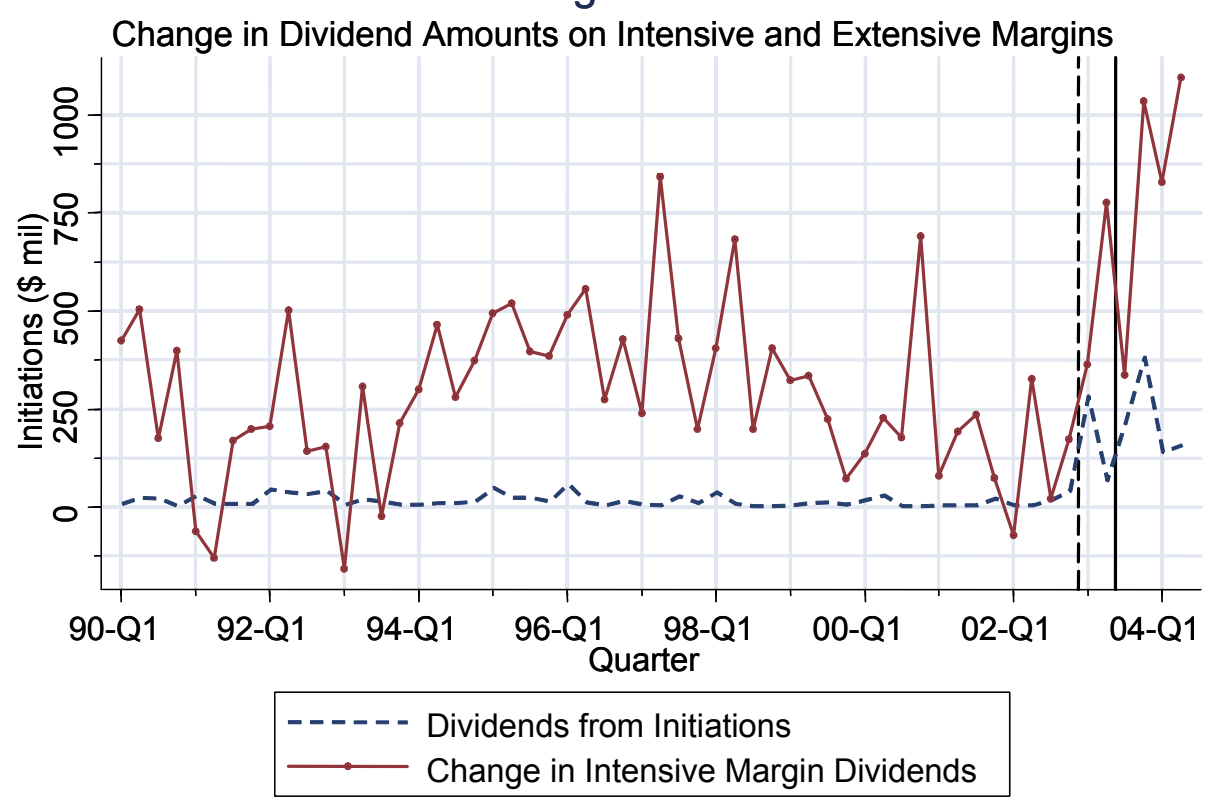

Figure 12b

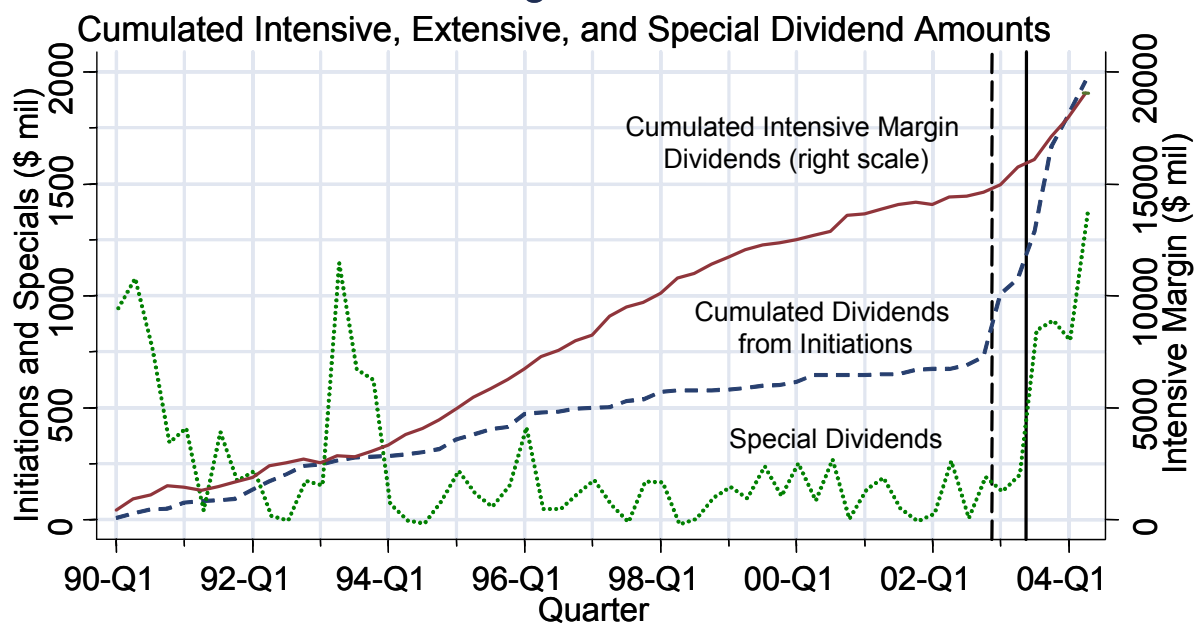

The sample consists of those firms in the constant number of firms sample that did not acquire another company in previous quarter. Panel A depicts the amounts (in real 2004 dollars) of regular dividends initiated in each quarter and the change in regular dividends on the intensive margin for firms paying regular dividends both in the current and previous quarter (initiations and terminations are excluded from this series).

Panel B depicts the cumulated (from 1990-Q1) amounts of regular dividend initiations (integral of the initiation graph in Panel A) and the amounts of special dividends on the left scale. It also shows the cumulated amounts (from 1990-Q1) of regular dividend intensive changes on the right scale (integral of the change in intensive margin dividends in Panel A). 
Figure 13

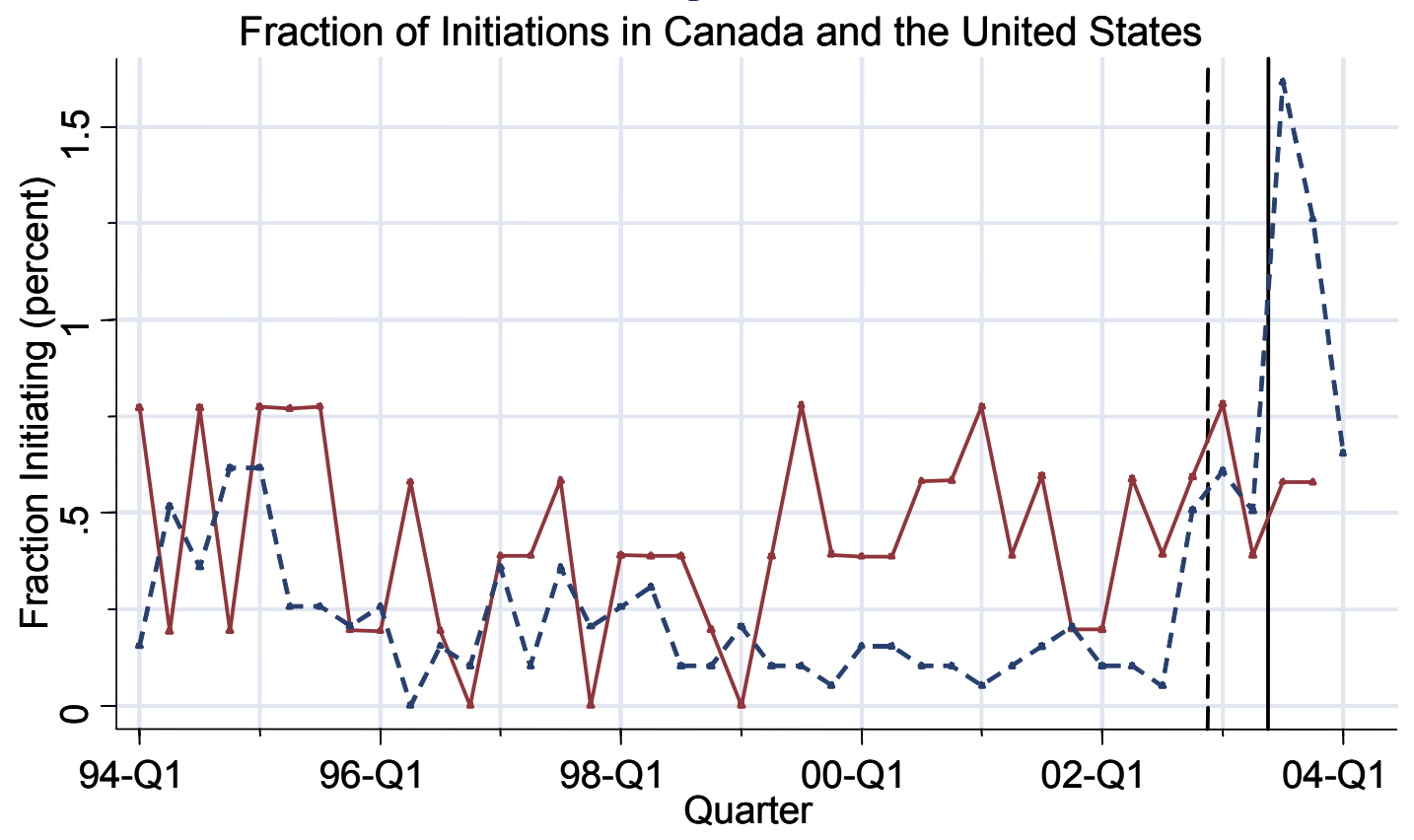

Fraction Init:: Canada ------ Fraction Init.: US

This figure depicts the fraction of firms initiating dividend payments in Canada and the United States. For Canada, the sample consists of Compustat Canada firms which are non financial, non utility, and incorporated in Canada in the last quarter and which remain in the sample from 1994-Q1 and 2004-Q2. For the United States, the data sample consists of CRSP firms which are non financial, non utility, and non foreign in the last quarter and which remain in the sample from 1994-Q1 and 2004-Q2. Initiation of dividends is defined as in Figure 2. 
Figure 14a

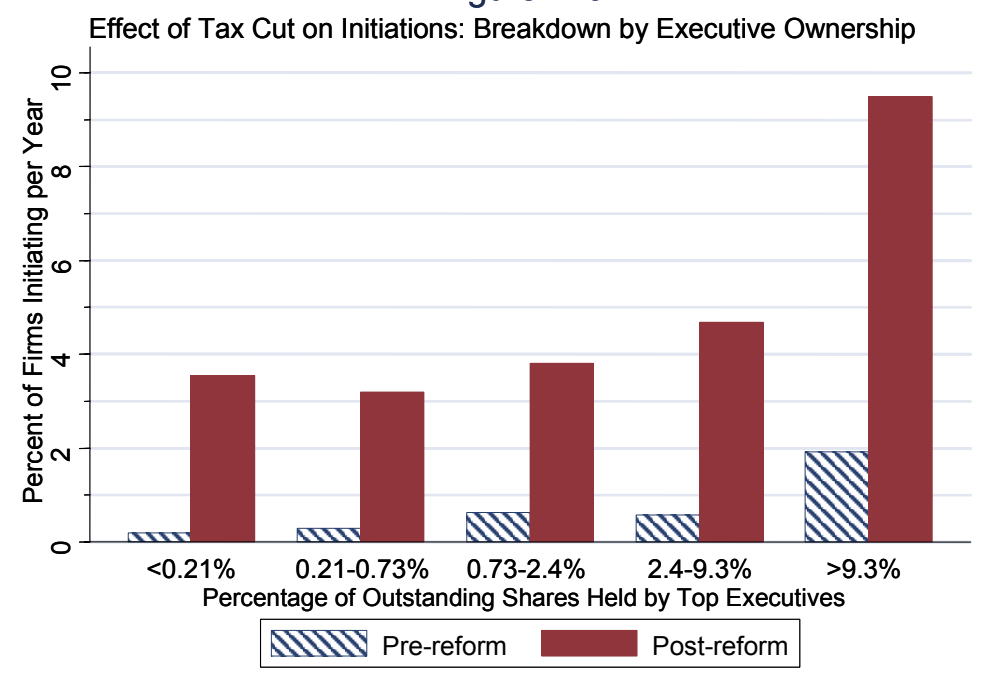

Figure $14 b$

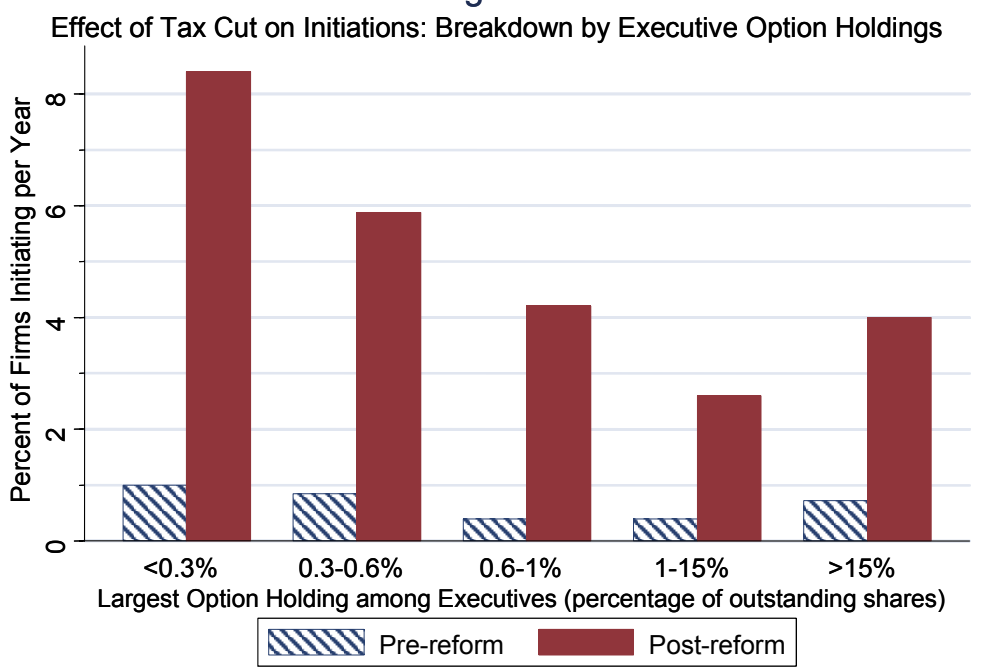

In both panels, the sample consists of all firms present in CRSP in each quarter from 1998-Q1 to 2004-Q2. All firms-quarters $(i, t)$ for which firm $i$ paid regular dividends in any of the previous four quarters $(t-1, t-2, t-3, t-4)$ are discarded from the sample (to focus only on firms not paying dividends previously).

Panel A depicts the percentage of firms initiating dividends at an annualized rate pre-reform (from 1998-Q1 to 2002-Q4) and post-reform (from 2003-Q1 to 2004-Q2) by quintiles of executive ownership. Executive ownership is defined by the share of the company owned by the executive with the largest share ownership. Executive share ownership is obtained from Execucomp data or directly collected from SEC proxy filings, as described in the appendix. The horizontal axis shows, for each quintile, the percentage range of shares owned by the largest executive owner.

Panel B depicts the percentage of firms initiating dividends (as in Panel A) by analogous quintiles of executive option holding. Executive option holding is defined by the fraction of shares of the company owned in the form of unexercisable stock-options (options which have been granted but are not yet vested and hence cannot yet be exercised) by the executive who has the largest unexercisable options holdings. 
Figure 15a

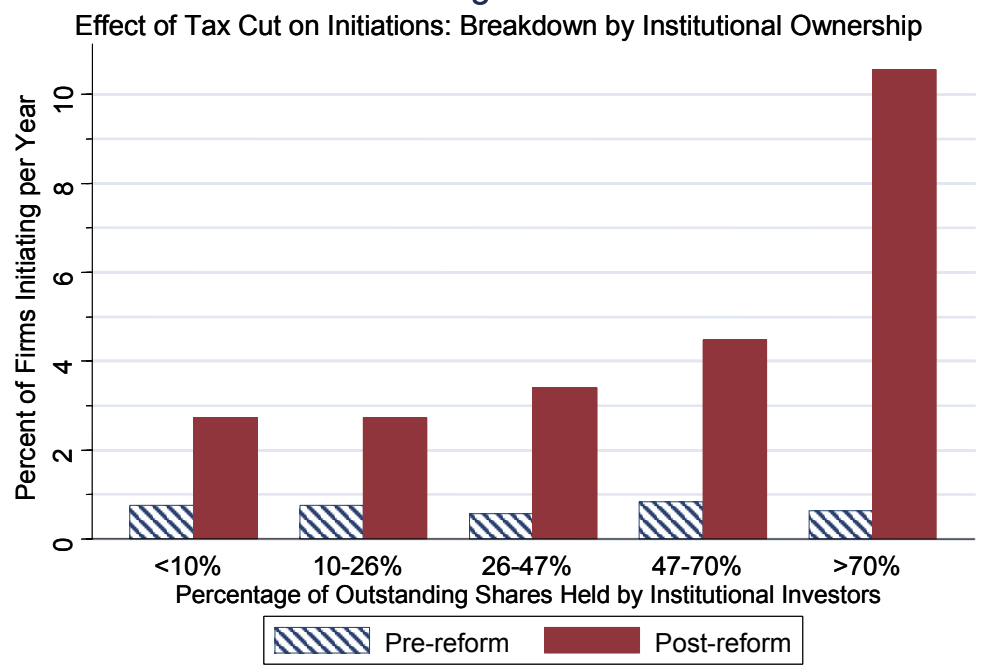

Figure 15b

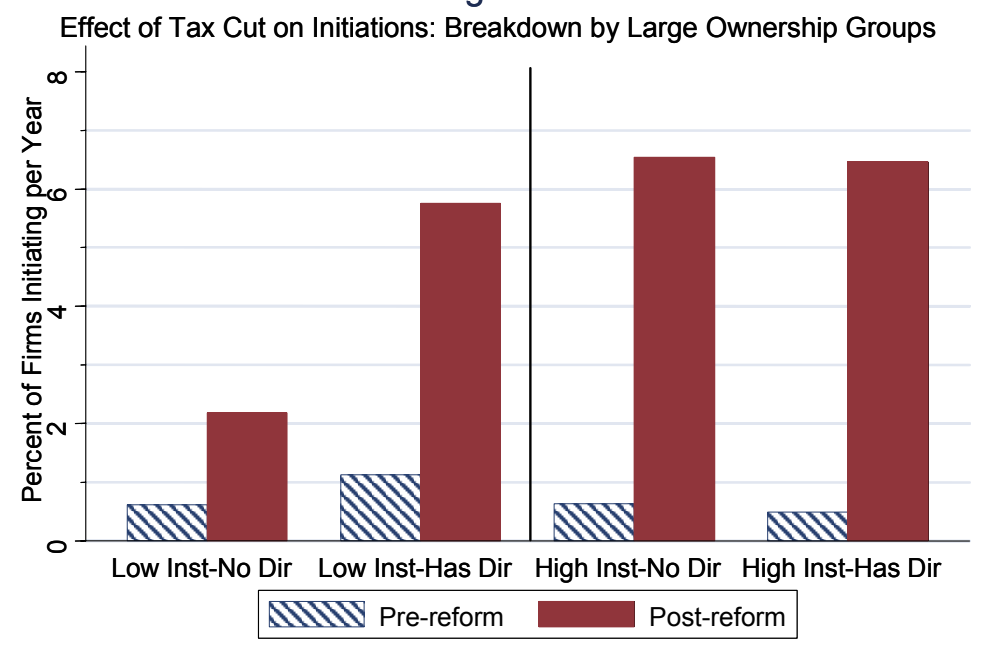

For both panels, the sample is the same as in Figure 14. Panel A depicts the percentage of firms initiating dividends at an annualized rate pre-reform (from 1998-Q1 to 2002-Q4) and post-reform (from 2003-Q1 to 2004-Q2) by quintiles of institutional share ownership. Institutional share ownership (from the Thomson financial database) is defined as the fraction of the firm owned by institutions such as mutual funds. The horizontal axis depicts, for each quintile, the percentage range of institutional share ownership.

Panel B breaks down the initiation rates by institutional ownership and large-shareholding independent directors. The "low inst" category consists of all firms with below-median institutional shareholding during sample period, and the "high inst" category consists of the rest. The "No Dir" category contains firms that do not have a large-shareholding independent director on their board; the "Has Dir" category contains the rest of the firms. The figure shows pre- and post-reform initiation rates for the four categories of firms across these two dimensions. Large-shareholding independent directors are defined as individuals on the board of directors who own at least $5 \%$ of the company and who are not officers. Data on large shareholders is obtained from the Dlugosz, Fahlenbrach, Gompers, and Metrick (2004) database and also supplemented by data from SEC proxy statements as described in the appendix. 


\section{Figure 16}

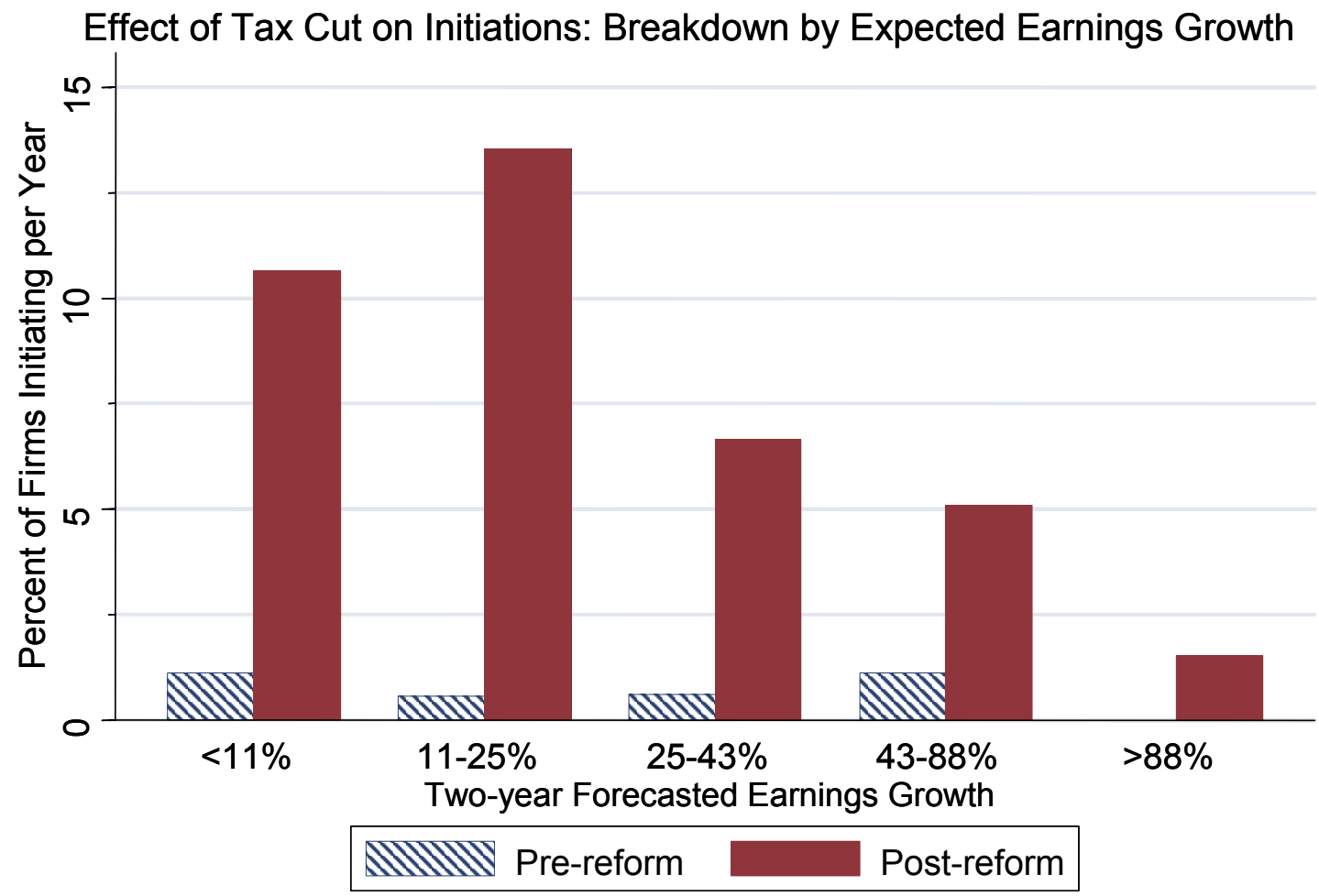

This figure depicts the percentage of firms initiating dividends at an annualized rate pre-reform (from 1998-Q1 to 2002-Q4) and post-reform (from 2003-Q1 to 2004-Q2) by quintiles of expected earnings growth. The sample is the same as in Figures 14. Expected earnings growth is defined using I/B/E/S data on analysts' earnings forecasts as follows. We first compute the expected change in earnings per share as the mean earnings per share forecast for a two year forecast period minus the actual earnings per share in the current year. We then multiply this figure by the total number of shares outstanding and divide by total assets to arrive at a normalized measure of earnings growth per dollar of assets. The five quintiles of earnings growth are defined over the sample of firm-quarter pairs (therefore, the quintiles are not constant overtime). The horizontal axis depicts, for each quintile, the percentage range of earnings growth forecast. 
Figure 17a
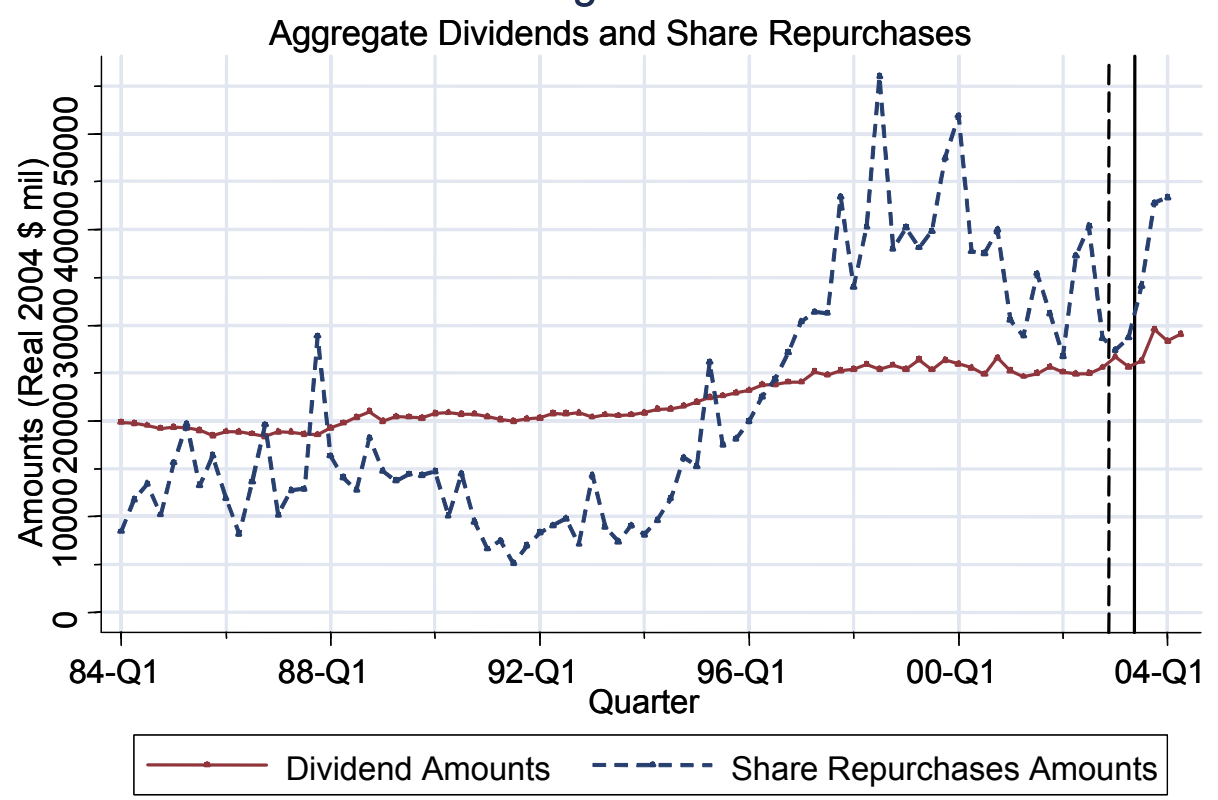

Figure $17 \mathrm{~b}$

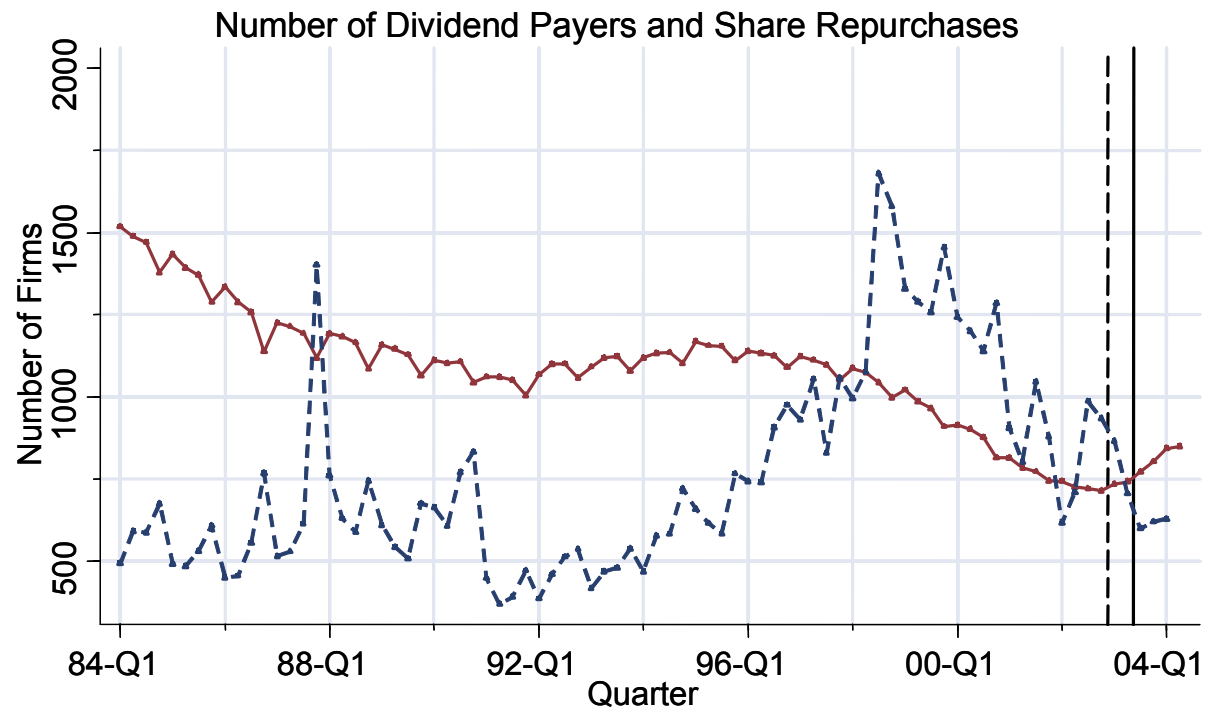

Dividend Payers

- - - - - Share Repurchasers $(.1 \%+)$

Panel A shows total regular dividend payments and total share repurchases (in real 2004-Q1 dollars). For regular dividends, the sample consists of all firm-quarters in the CRSP database which are non financial, non utility, and non foreign in their last quarter (core sample). For share repurchases, the sample is same as above but with the additional requirement that the firm appears in the quarterly compustat database and that the compustat variable share repurchase (item data93 in quarterly file: purchases of common and preferred stock) exists.

Panel B depicts the total number of firms making regular dividend payments and total number of firms repurchasing at least $0.1 \%$ of their shares from 1984-Q1 to 2004-Q2. The sample is the same as in Panel A. 


\section{Figure $18 \mathrm{a}$}

Fraction of Dividend Payers and Share Repurchases (High Ownership Sample)

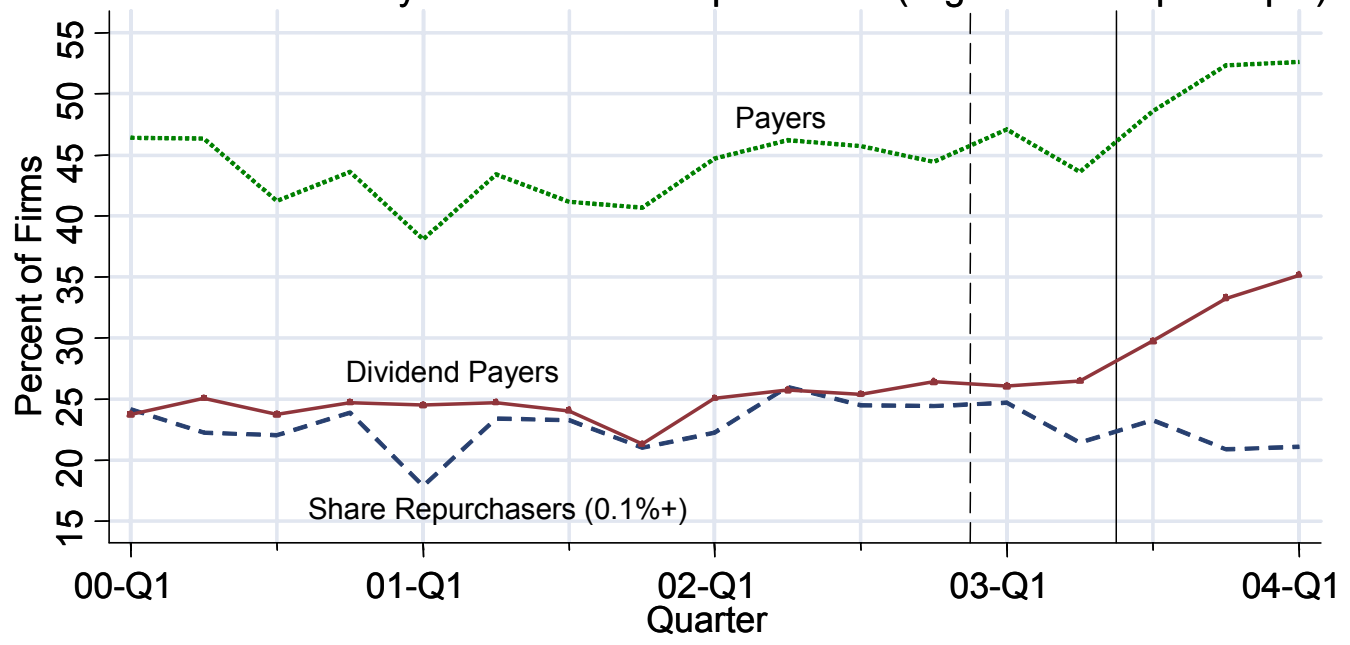

Figure 18b

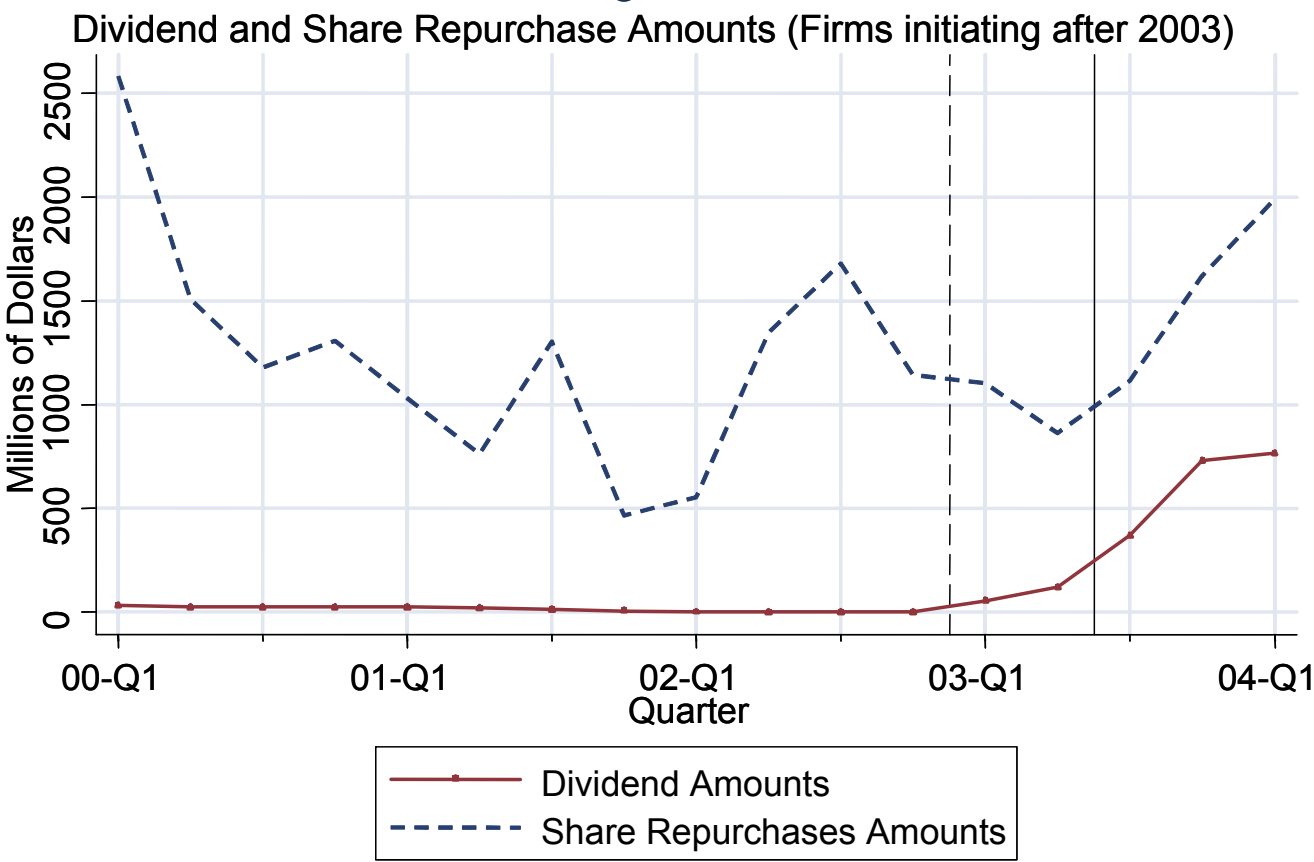

Panel A depicts the fraction of regular dividend payers and the fractions of firms either paying regular dividends or repurchasing at least $0.1 \%$ of their shares for each quarter from 1998-Q1 to 2004Q1. The sample consists of all firms in the core sample that are alive in all quarters from 1998-Q1 to 2004-Q1 and have one or more top executives who own at least $20 \%$ of their company's shares.

Panel B depicts the amount of regular dividends paid and the amount of share repurchases for the set of firms in the core sample who initiate regular dividend payments after the 2003 reform (between 2003-Q1 to 2004-Q2), and which have Compustat data on share repurchases. Microsoft is excluded from the sample in order to obtain smoother series that are not driven by an outlier. 


\section{Table 1}

Summary Statistics

\begin{tabular}{lcc|cc}
\hline \hline & \multicolumn{2}{c}{$\begin{array}{c}\text { Core Sample } \\
\text { (All Firms in CRSP) }\end{array}$} & $\begin{array}{r}\text { Constant Number of Firms Sample } \\
\text { (Top 3,807 firms) }\end{array}$ \\
\cline { 2 - 5 } Variables & Mean & St. Dev. & Mean & St. Dev. \\
\cline { 2 - 5 } Average Regular Dividends & 4.52 & 40.44 & 5.81 & 45.78 \\
Average Special Dividends & 0.10 & 10.36 & 0.13 & 11.74 \\
Average Share Repuchase & 5.32 & 64.72 & 6.88 & 73.52 \\
Fraction paying regular divs & $22.68 \%$ & $41.88 \%$ & $28.34 \%$ & $45.07 \%$ \\
Fraction paying special divs & $0.59 \%$ & $7.63 \%$ & $0.67 \%$ & $8.17 \%$ \\
Fraction Initiations & $0.24 \%$ & $4.91 \%$ & $0.29 \%$ & $5.38 \%$ \\
Fraction Terminations & $0.46 \%$ & $6.77 \%$ & $0.46 \%$ & $6.79 \%$ \\
Fraction Increases (20\%+) & $1.15 \%$ & $10.65 \%$ & $1.43 \%$ & $11.88 \%$ \\
Fraction Decreases (20\%+) & $0.17 \%$ & $4.17 \%$ & $0.21 \%$ & $4.62 \%$ \\
Fraction Repurchasing (0.1\%+) & $15.09 \%$ & $35.80 \%$ & $16.72 \%$ & $37.32 \%$ \\
Average Market Capitalization & 1125.82 & 8285.92 & & 1444.76 \\
Assets & 1148.76 & 8176.02 & 1456.16 & 9373.65 \\
Cash and liquid assets & 80.01 & 568.36 & 101.15 & 9212.09 \\
After-Tax Profits & 9.89 & 161.13 & 12.91 & 181.11 \\
& & & & \\
\hline
\end{tabular}

NOTE-Core sample includes all firm-quarters in CRSP that are non utility, non financial and non foreign in their last quarter from 1982-Q1 to 2004-Q2. Constant number of firms sample keeps only the top 3,807 firms ranked by market capitalization. All dollar amounts are in real 2004-Q1 millions of dollars. All variables are from CRSP sample except assets, cash, share repurchases, and profits, which are from COMPUSTAT. 
Table 2

Post Reform Initiations among Top 100 Largest Companies

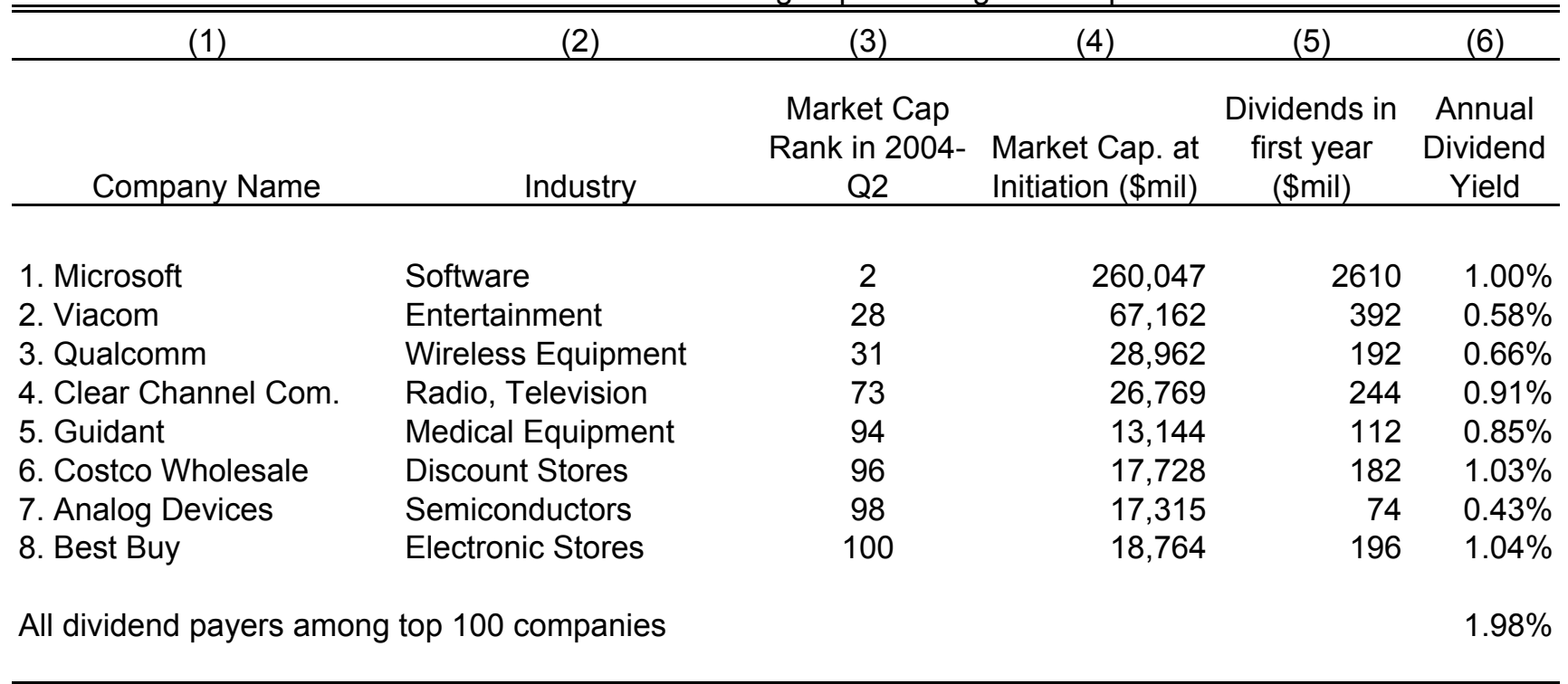

NOTE-The table lists all the companies among the top 100 (ranked by market capitalization in 2004-Q2) in the CRSP non financial, non utility, non foreign data which have initiated regular dividend payments from2003-Q1 to 2004-Q2.

Annual dividend yield and annual dividends based on payments made during first four quarters after initiation. (payments are extrapolated based on current payments if less than 4 quarters of data are available after initiation). Average yield among top 100 companies is not weighted by market capitalization. 
Table 3

Summary of Results

\begin{tabular}{lcccc}
\hline \hline & & & & \\
& $\begin{array}{c}\text { Pre-reform } \\
(01-Q 3-02-Q 4)\end{array}$ & $\begin{array}{c}\text { Post-reform } \\
\text { (03-Q1-04-Q2) }\end{array}$ & Change & $\begin{array}{c}\text { Change } \\
\text { with Controls }\end{array}$ \\
& $(1)$ & $(2)$ & $(3)$ & $(4)$ \\
\cline { 2 - 4 } \# Regular dividend Initiations per quarter & 4.33 & 29.00 & 24.67 & 26.82 \\
& $(0.85)$ & $(2.19)$ & $(2.32)$ & $(2.87)$ \\
\# Regular dividend increases (>20\%) & 19.00 & 49.83 & 30.83 & 29.66 \\
& $(1.78)$ & $(2.86)$ & $(3.22)$ & $(3.83)$ \\
\# Special dividend payers & 6.83 & 17.83 & 11.00 & 9.50 \\
& $(1.07)$ & $(1.72)$ & $(2.03)$ & $(2.30)$ \\
Change in regular dividends (per quarter) & 13.22 & 205.39 & 192.17 & 232.39 \\
due to initiations (real \$ mil) & $(4.83)$ & $(48.35)$ & $(48.51)$ & $(66.34)$ \\
Change in regular dividends (per quarter) & 126.65 & 739.48 & 612.82 & 560.70 \\
due to intensive margin (real \$ mil) & $(99.26)$ & $(127.43)$ & $(167.81)$ & $(217.01)$ \\
Special dividend amounts (per quarter) & 112.50 & 729.94 & 617.44 & 371.21 \\
(real \$ mil) & $(45.98)$ & $(151.40)$ & $(203.48)$ & $(233.99)$ \\
\hline
\end{tabular}

This table reports the average value pre-reform (6 quarters from 2001-Q3 to 2002-Q4) and post-reform (from 2003-Q1 to 2004-Q2), as well as the change post-pre reform (with no controls and with controls) for a number of variables of interest. The change with controls is obtained from an OLS regression including assets, levels and eight lags of profits/assets, cash/assets, mktcap/assets, and SIC dummies, as in specification (2) in the text. Standard errors are reported in parenthesis below the estimates. The sample is the top 3,807 firms in CRSP (ranked by market capitalization) in each quarter (excluding utilities, financial, and foreign). The number of regular dividend initiations is defined as firms starting to pay regular dividends after not having paid for 4 quarters (6 quarters if annual payer).

The number of regular dividend increases is defined as those firms increasing regular dividend payments by at least $20 \%$ in nominal terms in quarter $t$ (relative to the previous dividend payment). Dividend initiations are not counted as intensive increases or decreases. Change in regular dividends due to initiations defined as the dividend amount (normalized to quarterly) for regular dividend initiators. Change in regular dividends due to intensive margin defined as the change in dividend amount (normalized to quarter and relative to previous regular dividend payment) for firms paying dividends. 
Table 4

Initiation Rates by Tax Status of Largest Institutional Holder

\begin{tabular}{lccc}
\hline \hline & $\begin{array}{c}\text { Control } \\
\text { (Not Affected) }\end{array}$ & $\begin{array}{c}\text { Treatment } \\
\text { (Affected) }\end{array}$ & $\begin{array}{c}\text { Difference } \\
\text { bet. Groups }\end{array}$ \\
& $(1)$ & $(2)$ & $(3)$ \\
\cline { 2 - 4 } & $31.23 \%$ & $27.24 \%$ & $-3.99 \%$ \\
Fraction payers & 1.10 & 0.83 & -0.27 \\
Pre-reform & $(0.60)$ & $(0.16)$ & $(0.64)$ \\
(1998-Q1 to 2002-Q4) & 1,822 & 27,977 & \\
\# obs. & 1.02 & 5.11 & 4.09 \\
Post-reform & $(1.32)$ & $(0.28)$ & $(2.28)$ \\
(2003-Q1 to 2004-Q2) & 394 & 8,065 & \\
\# obs. & & & 4.36 \\
Difference: & -0.08 & 4.28 & $\mathbf{( 1 . 4 8 )}$ \\
Post-Pre & $(1.48)$ & $(0.32)$ & \\
\hline
\end{tabular}

NOTE-The sample is all CRSP firms present in all quarters from 1998-Q1 to 2004-Q2 (excluding utilities, financial, and foreign).

Control group (not affected) is defined as the firms whose largest institutional owner is not affected by the reform (either a pension fund, an insurance company, a nonprofit organization, a non-financial corporation, or a government agency). The treatment group (affected) are all other firms.

The table displays in row 1 the fraction of regular dividend payers among the two groups (average over the period).

The table displays the annual regular dividend initiation rate (among non payers) per quarter before and after the reform for the two groups as well as the difference between groups and before and after the reform. Standard errors are in parenthesis. 


\section{Table 5a}

Interaction of Executive Incentives

Post-Reform Annual Initiation Rate by Share and Option Holding Groups

\begin{tabular}{|c|c|c|c|c|}
\hline & & \multicolumn{3}{|c|}{$\begin{array}{l}\text { Largest Shareholding } \\
\text { Among Top Executives }\end{array}$} \\
\hline & & $<0.5 \%$ & $0.5-3.3 \%$ & $>3.3 \%$ \\
\hline Largest Unexercisable & $<0.5 \%$ & 5.00 & 3.31 & 11.42 \\
\hline Option Holding & $0.5-1.2 \%$ & 4.95 & 2.76 & 7.04 \\
\hline Among Executives & $>1.2 \%$ & 1.58 & 4.65 & 6.38 \\
\hline
\end{tabular}

Table 5b

Interaction between Agents and Principals

Post-Reform Annual Initiation Rate by Executive and Institutional Shareholding

\begin{tabular}{c|cccc}
\hline \hline & & \multicolumn{3}{c}{$\begin{array}{c}\text { Percentage of Shares } \\
\text { Held by Institutional Investors }\end{array}$} \\
\cline { 3 - 5 } & & & & \\
& & $\mathbf{3 5 \%} \%$ & $\mathbf{3 5} \%$ & $\mathbf{6 3 \%}$ \\
Largest Shareholding & $<\mathbf{0 . 5 \%}$ & 1.21 & 1.24 & 6.66 \\
Among Top & $\mathbf{0 . 5 - 3 . 3 \%}$ & 1.35 & 0.30 & 9.34 \\
Executives & $>\mathbf{3 . 3 \%}$ & 7.12 & 6.19 & 10.94 \\
& & & & \\
\hline
\end{tabular}

The tables report the annual dividend initiation rate after the reform (from 2003-Q1 to 2004-Q2) for firms alive from 1998-Q1 to 2004-Q2 in various groups. Groups are defined by size of option holdings and executive ownership in Panel $A$ and executive ownership and institutional ownership in Panel B. See Figures 14 and 15 for description of sample and variable definitions. 
Table A1

Aggregate Time Series for Core Sample

\begin{tabular}{|c|c|c|c|c|c|c|c|c|c|c|c|c|c|c|c|c|c|c|c|c|}
\hline Quarter & $\begin{array}{c}(2) \\
\text { Poterba } \\
\text { (2004) tax } \\
\text { pref. } \\
\end{array}$ & $\mathrm{CPI}$ & $\begin{array}{c}\text { Regular } \\
\text { dividends } \\
(\$ \mathrm{mn})\end{array}$ & $\begin{array}{c}\text { Special } \\
\text { dividends } \\
(\$ \mathrm{mn}) \\
\end{array}$ & $\begin{array}{c}\text { Share } \\
\text { repurchases } \\
(\$ \mathrm{mn})\end{array}$ & $\begin{array}{l}\text { Market Capit. } \\
\quad(\$ \text { bn })\end{array}$ & \# firms & $\begin{array}{c}(9) \\
\text { \# regular } \\
\text { dividend } \\
\text { payers } \\
\end{array}$ & $\begin{array}{c}(10) \\
\# \\
\# \text { special } \\
\text { payers } \\
\end{array}$ & $\begin{array}{c}\# \\
\text { initiations } \\
\end{array}$ & $\begin{array}{c}\# \\
\text { Is terminations }\end{array}$ & $\begin{array}{c}(13) \\
\\
\# \text { intensive } \\
\text { increase } \\
(20 \%+) \\
\end{array}$ & $\begin{array}{c}\# \text { intensive } \\
\text { decrease } \\
(20 \%+) \\
\end{array}$ & $\begin{array}{l}\text { \# share } \\
\text { repurch. } \\
(0.1 \%+) \\
\end{array}$ & $\begin{array}{c}\text { (16) } \\
\text { \# entrants } \\
\text { paying } \\
\text { dividends } \\
\end{array}$ & $\begin{array}{l}\text { \# leavers } \\
\text { who paid } \\
\text { dividends }\end{array}$ & $\begin{array}{c}(18) \\
\text { cumulative } \\
\text { net change } \\
\text { in payers } \\
\end{array}$ & $\begin{array}{c}\text { (19) } \\
\text { \# deliberate } \\
\text { dividend } \\
\text { payers } \\
\end{array}$ & $\begin{array}{c}(20) \\
\text { Reg. Div. } \\
\text { Initiations } \\
(\$ \mathrm{mn}) \\
\end{array}$ & $\begin{array}{c}(21) \\
\text { Intensive } \\
\text { changes in } \\
\text { dividends } \\
\text { (\$m) } \\
\end{array}$ \\
\hline 1981-Q3 & 0.748 & 0.535 & 19,980 & 63 & & 1,849 & 4,117 & 1,703 & 22 & 5 & & 110 & 14 & & & & & 1,703 & 2 & 369 \\
\hline 1981-Q4 & 0.748 & 0.543 & 19,601 & 217 & & 1804 & 4,191 & 1.499 & 39 & 5 & 38 & 71 & 13 & & 0 & 7 & -7 & 1.506 & 3 & 465 \\
\hline 1982-Q1 & 0.800 & 0.550 & 20,131 & 265 & & 1,638 & 4,190 & 1,676 & 91 & 20 & 44 & 109 & 22 & & 2 & 10 & -15 & 1,691 & 29 & 413 \\
\hline 1982-Q2 & 0.800 & 0.556 & 19,748 & 20 & & 1,579 & 4,177 & 1,605 & 26 & 9 & 46 & 50 & 31 & & 0 & 10 & -25 & 1,630 & 7 & 118 \\
\hline 1982-Q3 & 0.800 & 0.564 & 19,243 & 11 & & 1,577 & 4,158 & 1,570 & 19 & 6 & 43 & 45 & 41 & & 0 & 11 & -36 & 1,606 & 6 & 98 \\
\hline 1982-Q4 & 0.800 & 0.571 & 18,766 & 34 & & 1,900 & 4,185 & 1,452 & 36 & 4 & 40 & 56 & 52 & & 3 & 9 & -42 & 1,494 & 2 & -103 \\
\hline 1983-Q1 & 0.811 & 0.576 & 18,793 & 190 & & 2,096 & 4,206 & 1,540 & 56 & 16 & 37 & 86 & 56 & & 0 & 8 & -50 & 1,590 & 32 & 119 \\
\hline 1983-Q2 & 0.811 & 0.581 & 20,037 & 725 & & 2,365 & 4,311 & 1,513 & 34 & 5 & 21 & 99 & 26 & & 2 & 10 & -58 & 1,571 & 11 & 442 \\
\hline 1983-Q3 & 0.811 & 0.588 & 17,974 & 12 & & 2,357 & 4,470 & 1,426 & 16 & 16 & 36 & 93 & 11 & & 0 & 5 & -63 & 1,489 & 117 & 307 \\
\hline 1983-Q4 & 0.811 & 0.592 & 19,181 & 90 & & 2,338 & 4,629 & 1,415 & 48 & 13 & 21 & 106 & 14 & & 2 & 9 & -70 & 1,485 & 9 & 589 \\
\hline 1984-Q1 & 0.821 & 0.599 & 19,853 & 207 & 8,435 & 2,245 & 4,728 & 1,518 & 55 & 18 & 21 & 120 & 13 & 331 & 3 & 2 & -69 & 1,587 & 61 & 472 \\
\hline 1984-Q2 & 0.821 & 0.605 & 19,734 & 22 & 11,761 & 2,104 & 4,770 & 1,488 & 25 & 13 & 21 & 76 & 8 & 464 & 0 & 15 & -84 & 1,572 & 77 & -972 \\
\hline 1984-Q3 & 0.821 & 0.609 & 19,520 & 10 & 13,405 & 2,138 & 4,783 & 1,469 & 26 & 17 & 35 & 78 & 14 & 478 & 3 & 11 & -92 & 1,561 & 35 & 329 \\
\hline 1984-Q4 & 0.821 & 0.613 & 19,200 & 96 & 10,204 & 2,127 & 4,775 & 1,378 & 52 & 14 & 39 & 73 & 11 & 545 & 1 & 8 & -99 & 1,477 & 56 & 64 \\
\hline 1985-Q1 & 0.824 & 0.620 & 19,351 & 382 & 15,627 & 2,285 & 4,725 & 1,433 & 73 & 12 & 39 & 80 & 11 & 402 & 0 & 7 & -106 & 1,539 & 72 & 230 \\
\hline 1985-Q2 & 0.824 & 0.624 & 19,265 & 21 & 19,640 & 2,316 & 4,712 & 1,392 & 30 & 8 & 29 & 63 & 13 & 393 & 1 & 8 & -113 & 1,505 & 9 & 403 \\
\hline $1985-\mathrm{Q} 3$ & 0.824 & $\begin{array}{l}0.628 \\
0.628\end{array}$ & 19,034 & 15 & $\begin{array}{l}13,040 \\
13,237\end{array}$ & $\begin{array}{l}2,294 \\
\text { 2, }\end{array}$ & 4,702 & 1,370 & 21 & 8 & 30 & 51 & 14 & 427 & 4 & $\begin{array}{l}0 \\
12\end{array}$ & -121 & 1,491 & 5 & 52 \\
\hline 1985-Q4 & 0.824 & 0.633 & 18,446 & 68 & 16,350 & 2,400 & 4,709 & 1,288 & 48 & 12 & 34 & 51 & 15 & 483 & 0 & 8 & -129 & 1,417 & 7 & 109 \\
\hline 1986-Q1 & 0.826 & 0.638 & 18,874 & 191 & 11,878 & 2,637 & 4,677 & 1,334 & 61 & 9 & 36 & 87 & 19 & 367 & 1 & 10 & -138 & 1,472 & 113 & 369 \\
\hline 1986-Q2 & 0.826 & 0.638 & 18,847 & 943 & 8,174 & $\begin{array}{l}2,087 \\
2,887\end{array}$ & 4,771 & $\begin{array}{l}1,287 \\
\end{array}$ & 30 & 8 & 49 & 63 & 21 & 365 & 4 & 6 & -140 & 1,427 & 7 & 297 \\
\hline 1986-Q3 & 0.826 & 0.643 & 18,653 & 29 & 13,635 & 2,753 & 4,828 & 1,257 & 26 & 8 & 34 & 49 & 23 & 440 & 1 & 5 & -144 & 1,401 & 7 & 227 \\
\hline 1986-Q4 & 0.826 & 0.648 & 18,393 & 154 & 19,598 & 2,774 & 4,879 & 1,138 & 47 & 5 & 34 & 50 & 15 & 607 & 1 & 11 & -154 & 1,292 & 16 & 200 \\
\hline 1987-Q1 & 0.861 & 0.655 & 18,871 & 72 & 10,146 & 3,200 & 4,863 & 1,225 & 56 & 19 & 36 & 81 & 16 & 419 & 2 & 20 & -172 & 1,397 & 99 & 387 \\
\hline 1987-Q2 & 0.861 & 0.661 & 18,830 & 2,354 & 12,734 & 3,334 & 4,917 & 1,214 & 37 & 19 & 24 & 56 & 8 & 432 & 3 & 8 & -177 & 1,391 & 45 & 484 \\
\hline 1987-Q3 & 0.861 & 0.667 & 18,627 & 1,070 & 12,857 & 3,610 & 5,021 & 1,193 & 28 & 12 & 25 & 64 & 12 & 493 & 1 & 9 & -185 & 1,378 & 36 & 323 \\
\hline 1987-Q4 & 0.861 & 0.673 & 18,573 & 3,339 & 28,852 & 2,601 & 4,969 & 1,118 & 41 & 18 & 26 & 58 & 11 & 1,143 & 0 & 8 & -193 & 1,311 & 48 & 335 \\
\hline 1988-Q1 & 0.874 & 0.679 & 19,254 & 4,261 & 16,329 & 2,786 & 4,898 & 1,192 & 73 & 12 & 27 & 81 & 13 & 628 & 1 & 7 & -199 & 1,391 & 16 & 488 \\
\hline 1988-Q2 & 0.874 & 0.686 & 19,765 & 207 & 14,044 & 2,818 & 4,863 & 1,183 & 48 & 26 & 33 & 56 & 5 & 515 & 0 & 7 & -206 & 1,389 & 426 & 744 \\
\hline 1988-Q3 & 0.874 & 0.694 & 19,540 & 2,067 & 12,764 & 2,762 & 4,806 & 1,165 & 38 & 18 & 28 & 83 & 10 & 478 & 1 & 13 & -218 & 1,383 & 16 & 259 \\
\hline 1988-Q4 & 0.874 & 0.701 & 19,343 & 3,240 & 18,207 & 2,752 & 4,752 & 1,085 & 66 & 14 & 25 & 49 & 11 & 606 & 3 & 9 & -224 & 1,309 & 14 & 274 \\
\hline 1989-Q1 & 0.873 & 0.710 & 19,938 & 2,735 & 14,761 & 2,832 & 4,677 & 1,157 & 70 & 19 & 20 & 98 & 8 & 504 & 0 & 12 & -236 & 1,393 & 13 & 760 \\
\hline 1989-Q2 & 0.873 & 0.719 & 20,431 & 2,535 & 13,726 & 3,003 & 4,625 & 1,145 & 46 & 21 & 19 & 78 & 10 & 447 & 0 & 7 & -243 & 1,388 & 44 & 713 \\
\hline 1989-Q3 & 0.873 & 0.723 & 20,396 & 3,174 & 14,423 & 3,224 & 4,576 & 1,128 & 48 & 11 & 25 & 67 & 9 & 417 & 2 & 9 & -250 & 1,378 & 26 & 159 \\
\hline 1989-Q4 & 0.873 & 0.729 & 20,313 & 991 & 14,314 & 3,145 & 4,549 & 1,064 & 67 & 17 & 29 & 42 & 10 & 552 & 0 & 3 & -253 & 1,317 & 19 & 428 \\
\hline 1990-Q1 & 0.876 & 0.740 & 20,753 & 971 & 14,710 & 2,966 & 4,519 & 1,111 & 57 & 9 & 26 & 70 & 6 & 551 & 1 & 7 & -259 & 1,370 & 6 & 653 \\
\hline 1990-Q2 & 0.876 & 0.748 & 20,886 & 1,103 & 10,048 & 3,114 & 4,531 & 1,101 & 45 & 13 & 23 & 57 & 7 & 502 & 2 & 4 & -261 & 1,362 & 21 & 505 \\
\hline 1990-Q3 & 0.876 & 0.758 & 20,671 & 787 & 14,454 & 2,854 & 4,498 & 1,107 & 31 & 16 & 10 & 36 & 11 & 642 & 1 & 2 & -262 & 1,369 & 20 & 174 \\
\hline 1990-Q4 & 0.876 & 0.767 & 20,732 & 370 & 9,457 & 2,691 & 4,442 & 1,043 & 49 & 5 & 22 & 35 & 13 & 701 & 3 & 5 & -264 & 1,307 & 1 & 404 \\
\hline 1991-Q1 & 0.871 & 0.773 & 20,450 & 435 & $\begin{array}{l}\text { 6,4011 } \\
6,61\end{array}$ & $\begin{array}{l}3,091 \\
3,096\end{array}$ & $\begin{array}{l}4,442 \\
4,408\end{array}$ & $\begin{array}{l}1,061 \\
1,061\end{array}$ & 43 & 13 & 29 & 30 & 18 & 378 & 1 & 3 & $\begin{array}{l}-264 \\
-266\end{array}$ & $\begin{array}{l}1,327 \\
1,327\end{array}$ & 28 & $\begin{array}{l}404 \\
-58\end{array}$ \\
\hline 1991-Q2 & 0.871 & 0.777 & 20,151 & 66 & 7,478 & 3,256 & 4,455 & 1,060 & 20 & 10 & 19 & 42 & 25 & 307 & 0 & 1 & -267 & 1,327 & 6 & -119 \\
\hline 1991-Q3 & 0.871 & 0.783 & 19,993 & 417 & 5,100 & 3,372 & 4,471 & 1,051 & 27 & 7 & 18 & 28 & 21 & 323 & 1 & 2 & -268 & 1,319 & 5 & 169 \\
\hline 1991-Q4 & 0.871 & 0.789 & 20,205 & 198 & 6,940 & 3,444 & 4,515 & 1,004 & 31 & 6 & 11 & 37 & 21 & 389 & 0 & 3 & -271 & 1,275 & 6 & 306 \\
\hline 1992-Q1 & 0.871 & 0.795 & 20,281 & 242 & 8,302 & 3,650 & 4,579 & 1,068 & 31 & 26 & 16 & 40 & 19 & 325 & 1 & 2 & -272 & 1,340 & 42 & 208 \\
\hline 1992-Q2 & 0.871 & 0.800 & 20,766 & 42 & 9,032 & 3,602 & 4,643 & 1,099 & 15 & 19 & 12 & 55 & 18 & 386 & 2 & 0 & -270 & 1,369 & 36 & 512 \\
\hline 1992-Q3 & 0.871 & 0.806 & 20,739 & 315 & 9,781 & 3,601 & 4,599 & 1,100 & 14 & 12 & 13 & 42 & 21 & 431 & 1 & 2 & -271 & 1,371 & 31 & 174 \\
\hline 1992-Q4 & 0.871 & 0.811 & 20,838 & 199 & 7,082 & 3,744 & 4,620 & 1,058 & 33 & 10 & 21 & 32 & 15 & 452 & 0 & 0 & -271 & 1,329 & 40 & 159 \\
\hline 1993-Q1 & 0.860 & 0.815 & 20,410 & 179 & 14,313 & 3,859 & 4,692 & 1,091 & 22 & 9 & 17 & 67 & 25 & 361 & 1 & 0 & -270 & 1,361 & 5 & -158 \\
\hline 1993-Q2 & 0.860 & 0.820 & 20,643 & 1,171 & 8,869 & 3,889 & 4,775 & 1,118 & 21 & 20 & 14 & 48 & 13 & 400 & 0 & 4 & -274 & 1,392 & 18 & 308 \\
\hline 1993-Q3 & 0.860 & 0.823 & 20,568 & 702 & 7,388 & 4,007 & 4,890 & 1,122 & 10 & 14 & 15 & 47 & 19 & 406 & 5 & 1 & -270 & 1,392 & 13 & -23 \\
\hline 1993-Q4 & 0.860 & 0.828 & 20,647 & 651 & 9,047 & 4,208 & 5,061 & 1,078 & 26 & 6 & 21 & 36 & 17 & 450 & 2 & 1 & -269 & 1,347 & 10 & 215 \\
\hline 1994-Q1 & 0.862 & 0.831 & 20,864 & 98 & 8,100 & 4,278 & 5,165 & 1,118 & 19 & 9 & 19 & 63 & 9 & 407 & 0 & 2 & -271 & 1,389 & 4 & 368 \\
\hline 1994-Q2 & 0.862 & 0.835 & 21,226 & 22 & 9,596 & 4,090 & 5,275 & 1,132 & 12 & 14 & 14 & 50 & 5 & 497 & 0 & 0 & -271 & 1,403 & 9 & 465 \\
\hline 1994-Q3 & 0.862 & 0.843 & 21,263 & 9 & $\begin{array}{l}11,881 \\
11\end{array}$ & $\begin{array}{l}4,236 \\
4\end{array}$ & 5,316 & 1,135 & 12 & 14 & 9 & 50 & 6 & 503 & 1 & 2 & -272 & $\begin{array}{l}1,407 \\
1,407\end{array}$ & 8 & 284 \\
\hline 1994-Q4 & 0.862 & 0.847 & 21,545 & 120 & 16,141 & 4,252 & 5,369 & 1,101 & 21 & 18 & 14 & 44 & 5 & 617 & 0 & 4 & -276 & 1,377 & 13 & 462 \\
\hline
\end{tabular}




\begin{tabular}{|c|c|c|c|c|c|c|c|c|c|c|c|c|c|c|c|c|c|c|c|c|}
\hline 1995-Q1 & 0.858 & 0.851 & 21,982 & 242 & 15,275 & 4,423 & 5,382 & 1,168 & 26 & 26 & 14 & 68 & 11 & 575 & 1 & 0 & -275 & 1,443 & 54 & 500 \\
\hline 1995-Q2 & 0.858 & 0.855 & 22,459 & 139 & 26,157 & 4,812 & 5,431 & 1,156 & 17 & 16 & 21 & 64 & 11 & 525 & 0 & 1 & -276 & 1,432 & 161 & 574 \\
\hline 1995-Q3 & 0.858 & 0.859 & 22,625 & 83 & 17,493 & 5,231 & 5,464 & 1,154 & 15 & 9 & 17 & 53 & 9 & 494 & 1 & 5 & -280 & 1,434 & 22 & 402 \\
\hline 1995-Q4 & 0.858 & 0.863 & 22,930 & 180 & 18,130 & 5,499 & 5,570 & 1,110 & 25 & 8 & 16 & 53 & 10 & 624 & 1 & 2 & -281 & 1,391 & 12 & 425 \\
\hline 1996-Q1 & 0.859 & 0.868 & 23,208 & 443 & 19,952 & 5,830 & 5,644 & 1,139 & 27 & 11 & 22 & 69 & 10 & 617 & 2 & 5 & -284 & 1,423 & 57 & 555 \\
\hline 1996-Q2 & 0.859 & 0.874 & 23,774 & 71 & 22,517 & 6,263 & 5,784 & 1,132 & 16 & 8 & 19 & 49 & 12 & 608 & 1 & 8 & -291 & 1,423 & 9 & 639 \\
\hline 1996-Q3 & 0.859 & 0.877 & 23,813 & 73 & 24,341 & 6,075 & 5,876 & 1,125 & 13 & 4 & 13 & 41 & 8 & 737 & 2 & 3 & -292 & 1,417 & 2 & 285 \\
\hline 1996-Q4 & 0.859 & 0.883 & 24,072 & 141 & 27,126 & 6,591 & 5,985 & 1,089 & 23 & 8 & 17 & 44 & 5 & 774 & 4 & 9 & -297 & 1,386 & 15 & 455 \\
\hline 1997-Q1 & 0.846 & 0.887 & 24,080 & 202 & 30,385 & 6,821 & 6,007 & 1,122 & 25 & 9 & 14 & 66 & 11 & 779 & 4 & 9 & -302 & 1,424 & 4 & 300 \\
\hline 1997-Q2 & 0.846 & 0.889 & 25,131 & 99 & 31,387 & 7,338 & 6,021 & 1,112 & 19 & 5 & 11 & 48 & 12 & 865 & 0 & 7 & -309 & 1,421 & 2 & 858 \\
\hline 1997-Q3 & 0.846 & 0.891 & 24,798 & 16 & 31,258 & 8,262 & 6,060 & 1,097 & 8 & 13 & 17 & 41 & 8 & 664 & 1 & 6 & -314 & 1,411 & 27 & 466 \\
\hline 1997-Q4 & 0.846 & 0.894 & 25,252 & 199 & 43,447 & 8,256 & 6,076 & 1,052 & 16 & 7 & 18 & 52 & 9 & 820 & 4 & 12 & -322 & 1,374 & 7 & 523 \\
\hline 1998-Q1 & 0.842 & 0.895 & 25,370 & 193 & 34,032 & 9,042 & 6,015 & 1,087 & 17 & 9 & 12 & 52 & 11 & 813 & 0 & 9 & -331 & 1,418 & 34 & 414 \\
\hline 1998-Q2 & 0.842 & 0.896 & 25,920 & 32 & 40,261 & 9,659 & 5,996 & 1,074 & 14 & 10 & 22 & 44 & 8 & 851 & 2 & 3 & -332 & 1,406 & 7 & 689 \\
\hline 1998-Q3 & 0.842 & 0.899 & 25,416 & 27 & 56,033 & 8,819 & 5,910 & 1,044 & 6 & 2 & 20 & 40 & 10 & 1,341 & 0 & 7 & -339 & 1,383 & 1 & 128 \\
\hline 1998-Q4 & 0.842 & 0.903 & 25,834 & 131 & 38,026 & 9,950 & 5,763 & 997 & 9 & 2 & 18 & 33 & 13 & 1,253 & 0 & 6 & -345 & 1,342 & 8 & 534 \\
\hline 1999-Q1 & 0.834 & 0.905 & 25,377 & 176 & 40,207 & 10,952 & 5,614 & 1,021 & 27 & 6 & 18 & 31 & 15 & 1,102 & 1 & 6 & -350 & 1,371 & 17 & 507 \\
\hline 1999-Q2 & 0.834 & 0.911 & 26,412 & 218 & 38,110 & 11,566 & 5,544 & 986 & 20 & 5 & 29 & 29 & 14 & 1,029 & 0 & 14 & -364 & 1,350 & 8 & 390 \\
\hline 1999-Q3 & 0.834 & 0.916 & 25,360 & 265 & 39,856 & 11,509 & 5,519 & 964 & 12 & 3 & 22 & 22 & 9 & 987 & 3 & 6 & -367 & 1,331 & 9 & 282 \\
\hline 1999-Q4 & 0.834 & 0.921 & 26,371 & 163 & 47,491 & 13,089 & 5,475 & 910 & 18 & 6 & 23 & 21 & 14 & 1,120 & 1 & 17 & -383 & 1,293 & 4 & 115 \\
\hline 2000-Q1 & 0.847 & 0.929 & 25,951 & 277 & 51,913 & 14,344 & 5,431 & 914 & 21 & 6 & 27 & 37 & 15 & 1,006 & 0 & 12 & -395 & 1,309 & 17 & 1,312 \\
\hline 2000-Q2 & 0.847 & 0.934 & 25,566 & 146 & 37,725 & 13,978 & 5,413 & 901 & 11 & 8 & 17 & 22 & 7 & 950 & 1 & 3 & -397 & 1,298 & 28 & 299 \\
\hline 2000-Q3 & 0.847 & 0.938 & 24,880 & 294 & 37,517 & 14,128 & 5,408 & 877 & 11 & 2 & 21 & 23 & 9 & 892 & 0 & 8 & -405 & 1,282 & 0 & -77 \\
\hline 2000-Q4 & 0.847 & 0.942 & 26,588 & 35 & 39,967 & 12,305 & 5,306 & 815 & 11 & 3 & 26 & 16 & 7 & 1,004 & 2 & 16 & -419 & 1,234 & 1 & 720 \\
\hline 2001-Q1 & 0.852 & 0.950 & 25,231 & 174 & 30,538 & 11,089 & 5,125 & 814 & 12 & 2 & 33 & 28 & 17 & 746 & 0 & 4 & -423 & 1,237 & 2 & 80 \\
\hline 2001-Q2 & 0.852 & 0.956 & 24,634 & 213 & 28,861 & 10,891 & 4,968 & 784 & 12 & 4 & 18 & 16 & 17 & 646 & 1 & 6 & -428 & 1,212 & 2 & 148 \\
\hline 2001-Q3 & 0.852 & 0.957 & 24,974 & 161 & 35,401 & 9,778 & 4,772 & 773 & 8 & 3 & 18 & 22 & 13 & 845 & 1 & 4 & -431 & 1,204 & 2 & 324 \\
\hline 2001-Q4 & 0.852 & 0.959 & 25,630 & 17 & 31,227 & 9,727 & 4,629 & 744 & 7 & 5 & 28 & 16 & 23 & 702 & 1 & 4 & -434 & 1,178 & 22 & 137 \\
\hline 2002-Q1 & 0.863 & 0.961 & 25,111 & 58 & 26,747 & 9,849 & 4,497 & 743 & 14 & 2 & 19 & 18 & 20 & 512 & 0 & 4 & -438 & 1,181 & 2 & 136 \\
\hline 2002-Q2 & 0.863 & 0.967 & 24,916 & 290 & 37,256 & 9,015 & 4,407 & 726 & 13 & 3 & 9 & 25 & 5 & 584 & 1 & 4 & -441 & 1,167 & 2 & 353 \\
\hline 2002-Q3 & 0.863 & 0.972 & 24,965 & 31 & 40,367 & 7,473 & 4,300 & 721 & 9 & 2 & 6 & 19 & 7 & 818 & 0 & 2 & -443 & 1,164 & 16 & 113 \\
\hline 2002-Q4 & 0.863 & 0.976 & 25,604 & 214 & 28,669 & 7,692 & 4,207 & 714 & 6 & 14 & 8 & 16 & 12 & 766 & 0 & 3 & -446 & 1,160 & 38 & 303 \\
\hline 2003-Q1 & 0.930 & 0.983 & 26,700 & 149 & 27,402 & 7,190 & 4,092 & 735 & 10 & 14 & 7 & 27 & 4 & 734 & 0 & 4 & -450 & 1,185 & 281 & 394 \\
\hline 2003-Q2 & 0.930 & 0.985 & 25,629 & 225 & 28,699 & 8,086 & 3,975 & 741 & 9 & 17 & 5 & 28 & 3 & 594 & 1 & 1 & -450 & $\begin{array}{l}1,191 \\
1\end{array}$ & 66 & 779 \\
\hline $2003-Q 3$ & 0.930 & 0.989 & 26,269 & 874 & 34,071 & 8,646 & 3,902 & 772 & 24 & 46 & 9 & 40 & 7 & 500 & 1 & 0 & -449 & 1,221 & 213 & 338 \\
\hline 2003-Q4 & 0.930 & 0.992 & 29,514 & 915 & 42,790 & 9,396 & 3,861 & 803 & 21 & 40 & 8 & 61 & 6 & 501 & 0 & 2 & -451 & 1,254 & 379 & 1,036 \\
\hline 2004-Q1 & 0.930 & 1.000 & 28,357 & 826 & 43,363 & 9,802 & 3,812 & 843 & 26 & 33 & 4 & 77 & 6 & 485 & 1 & 3 & -453 & 1,296 & 139 & 833 \\
\hline 2004-Q2 & 0.930 & 1.008 & 29,094 & 1,392 & & 9,763 & 3,807 & 848 & 20 & 24 & 11 & 67 & 2 & & 0 & 1 & -454 & 1,302 & 158 & 1,136 \\
\hline
\end{tabular}

Notes: Data sample consists all CRSP firms which are non financial, non utilities, and non foreign in their last quarter. For share repurchase variables, the firms must also have share repurchase information in COMPUSTAT (data93) Col. (2) is the tax preference parameter from Poterba (2004). It is defined as the average of (1-tdiv)/(1-tcg) where tdiv is marginal tax rate on dividend income and tcg is the marginal tax rate on capital gains.

Col. (3) is the Consumer Price Index (base 1 in 2004-Q1). All amounts are expressed in real 2004-Q1 dollars. Col. (4) is the total amount of regular dividends. Col. (5) is the total amount of special divident
Col. (6) is the total amount of share repurchases computed with data93 item in the COMPUSTAT quarterly d data (purchases of common and preferred stock). Col (7) is market capitalization (in \$bn).

Col. (8) is the number of firms, col. (9) is the number of regular dividend payers, col. (10) is the number of special dividend payers.

Col. (11) is the number of regular dividend initiations defined as starting to pay regular dividends after not having paid for 4 quarters (6 quarters if annual payer).

Col. (12) is the number of regular dividend terminations defined as stopping regular dividends payments (see text for details).

Col. (13) (resp. (14)) are the number of intensive reg. div, increases (resp. decreases) by at least $20 \%$ in real terms in quarter $\mathrm{t}$ (relative to quarters $\mathrm{t}-1$ and $\mathrm{t}-4$ ). Dividend initiations are not counted as intensive increases or decreases. Col (10) is the numer of firms

. Col. (17) is the number of firms leaving the core sample and which were regular dividend payers.

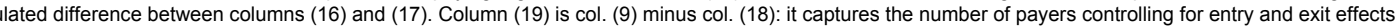

Col. (20) is the amounts of regular dividend initiations defined as starting to pay regular dividends after not having paid for 4 quarters (6 quarters if annual payer)

. The solid line marks the time at which the tax reform was enacted (end of May 2003) and the dashed line the time at which the tax reform was retrospectively applied (January 1st, 2003) 
Table A2

Aggregate Time Series for Constant Number of Firms Sample

\begin{tabular}{|c|c|c|c|c|c|c|c|c|c|c|c|c|c|c|c|c|c|c|c|c|}
\hline Quarter & $\begin{array}{c}\text { Poterba } \\
(2004) \text { tax } \\
\text { pref. }\end{array}$ & $\mathrm{CPI}$ & $\begin{array}{c}\text { Regular } \\
\text { dividends } \\
(\$ \mathrm{mn})\end{array}$ & $\begin{array}{c}\text { Special } \\
\text { dividends } \\
(\$ \mathrm{mn})\end{array}$ & $\begin{array}{l}\text { Share } \\
\text { repurchas } \\
\text { es }(\$ \mathrm{mn}) \\
\end{array}$ & $\begin{array}{c}\text { Market } \\
\text { Capit. (\$ } \\
\text { bn) }\end{array}$ & \# firms & $\begin{array}{c}\text { \# regular } \\
\text { dividend } \\
\text { payers }\end{array}$ & $\begin{array}{c}(10) \\
\# \\
\text { special } \\
\text { payers } \\
\end{array}$ & $\begin{array}{c}\# \\
\text { initiations } \\
\end{array}$ & $\begin{array}{c}\# \\
\text { terminations } \\
\end{array}$ & $\begin{array}{c}\# \text { intensive } \\
\text { increase } \\
(20 \%+) \\
\end{array}$ & $\begin{array}{c}\text { \# intensive } \\
\text { decrease } \\
(20 \%+)\end{array}$ & $\begin{array}{l}\text { \# share } \\
\text { repurch. } \\
(0.1 \%+) \\
\end{array}$ & $\begin{array}{c}\text { (16) } \\
\text { \# entrants } \\
\text { paying } \\
\text { dividends } \\
\end{array}$ & $\begin{array}{l}\text { \# leavers } \\
\text { who paid } \\
\text { dividends }\end{array}$ & $\begin{array}{c}\text { cumulative } \\
\text { net change } \\
\text { in payers }\end{array}$ & $\begin{array}{c}\text { (19) } \\
\text { \# deliberate } \\
\text { dividend } \\
\text { payers }\end{array}$ & $\begin{array}{c}(20) \\
\text { Reg. Div. } \\
\text { Initiations } \\
(\$ \mathrm{mn}) \\
\end{array}$ & $\begin{array}{c}(21) \\
\text { Intensive } \\
\text { changes in } \\
\text { dividends } \\
(\$ \mathrm{mn}) \\
\end{array}$ \\
\hline 1981-Q3 & 0.748 & 0.535 & 19,951 & 63 & & 1,849 & 3,807 & 1,695 & 21 & 5 & & 109 & 13 & & & & & 1,695 & 2 & 369 \\
\hline 1981-Q4 & 0.748 & 0.543 & 19,595 & 216 & & 1,803 & 3,807 & 1,489 & 37 & 5 & 29 & 70 & 13 & & 1 & 16 & -15 & 1,504 & 3 & 465 \\
\hline 1982-Q1 & 0.800 & 0.550 & 20,129 & 261 & & 1,637 & 3,807 & 1,664 & 90 & 19 & 40 & 107 & 21 & & 4 & 14 & -25 & 1,689 & 29 & 412 \\
\hline 1982-Q2 & 0.800 & 0.556 & 19,746 & 20 & & 1,578 & 3,807 & 1,596 & 23 & 8 & 44 & 50 & 31 & & 2 & 13 & -36 & 1,632 & 7 & 118 \\
\hline 1982-Q3 & 0.800 & 0.564 & 19,240 & 11 & & 1,576 & 3,807 & 1,566 & 19 & 6 & 37 & 44 & 41 & & 3 & 17 & -50 & 1,616 & 6 & 98 \\
\hline 1982-Q4 & 0.800 & 0.571 & $\begin{array}{l}18,746 \\
\end{array}$ & 34 & & 1,900 & $\begin{array}{l}3,807 \\
3,\end{array}$ & 1,447 & 36 & 4 & 39 & 55 & 51 & & 5 & 12 & -57 & 1,504 & 2 & -103 \\
\hline 1983-Q1 & 0.811 & 0.576 & 18,776 & 190 & & 2,095 & 3,807 & 1,532 & 56 & 16 & 30 & 86 & 55 & & 3 & 17 & -71 & 1,603 & 32 & 119 \\
\hline 1983-Q2 & 0.811 & 0.581 & 20,036 & 725 & & 2,364 & 3,807 & 1,505 & 34 & 5 & 18 & 99 & 26 & & 2 & 12 & -81 & 1,586 & 11 & 442 \\
\hline 1983-Q3 & 0.811 & 0.588 & 17,973 & 12 & & 2,354 & 3,807 & 1,417 & 14 & 15 & 30 & 93 & 11 & & 1 & 16 & -96 & 1,513 & 117 & 307 \\
\hline 1983-Q4 & 0.811 & 0.592 & 19,180 & 87 & & 2,333 & 3,807 & 1,396 & 43 & 12 & 16 & 105 & 13 & & 2 & 17 & -111 & 1,507 & 9 & 589 \\
\hline 1984-Q1 & 0.821 & 0.599 & 19,843 & 207 & 8,432 & 2,240 & 3,807 & 1,491 & 52 & 17 & 16 & 117 & 12 & 307 & 4 & 13 & -120 & 1,611 & 61 & 472 \\
\hline 1984-Q2 & 0.821 & 0.605 & 19,728 & 22 & 11,749 & 2,099 & 3,807 & 1,463 & 23 & 12 & 16 & 76 & 8 & 420 & 2 & 18 & -136 & 1,599 & 77 & -972 \\
\hline 1984-Q3 & 0.821 & 0.609 & 19,514 & 9 & 13,397 & 2,133 & 3,807 & 1,452 & 23 & 14 & 25 & 78 & 14 & 443 & 5 & 19 & -150 & 1,602 & 35 & 329 \\
\hline 1984-Q4 & 0.821 & 0.613 & 19,196 & 96 & 10,194 & 2,123 & 3,807 & 1,356 & 50 & 14 & 29 & 67 & 9 & 491 & 4 & 16 & -162 & 1,518 & 56 & 64 \\
\hline 1985-Q1 & 0.824 & 0.620 & 19,347 & 381 & 15,617 & 2,281 & 3,807 & 1,416 & 69 & 12 & 34 & 80 & 10 & 354 & 5 & 14 & -171 & 1,587 & 72 & 230 \\
\hline 1985-Q2 & 0.824 & 0.624 & 19,263 & 18 & 19,633 & 2,313 & 3,807 & 1,375 & 28 & 7 & 22 & 63 & 12 & 356 & 3 & 14 & -182 & 1,557 & 9 & 403 \\
\hline 1985-Q3 & 0.824 & 0.628 & 19,031 & 14 & 13,226 & 2,291 & 3,807 & 1,360 & 19 & 8 & 30 & 51 & 13 & 387 & 8 & 13 & -187 & 1,547 & 5 & 52 \\
\hline 1985-Q4 & 0.824 & 0.633 & 18,442 & 66 & 16,349 & 2,397 & 3,807 & 1,269 & 45 & 12 & 30 & 51 & 12 & 428 & 0 & 15 & -202 & 1,471 & 7 & 109 \\
\hline 1986-Q1 & 0.826 & 0.638 & 18,872 & 190 & 11,861 & 2,633 & 3,807 & 1,321 & 58 & 9 & 27 & 86 & 19 & 329 & 1 & 15 & -216 & 1,537 & 113 & 369 \\
\hline 1986-Q2 & 0.826 & 0.638 & 18,846 & 943 & 8,167 & 2,883 & 3,807 & 1,275 & 27 & 8 & 40 & 62 & 21 & 329 & 5 & 13 & -224 & 1,499 & 7 & 297 \\
\hline 1986-Q3 & 0.826 & 0.643 & 18,652 & 28 & 13,626 & 2,748 & 3,807 & 1,248 & 21 & 8 & 26 & 49 & 23 & 399 & 2 & 14 & -236 & 1,484 & 7 & 227 \\
\hline 1986-Q4 & 0.826 & 0.648 & 18,368 & 153 & 19,509 & 2,769 & 3,807 & 1,120 & 43 & 5 & 27 & 50 & 13 & 541 & 2 & 24 & -258 & 1,378 & 16 & 201 \\
\hline 1987-Q1 & 0.861 & 0.655 & 18,854 & 71 & 10,127 & 3,195 & 3,807 & 1,208 & 52 & 18 & 26 & 80 & 14 & 362 & 2 & 28 & -284 & 1,492 & 99 & 386 \\
\hline 1987-Q2 & 0.861 & 0.661 & $\begin{array}{l}18,825 \\
\end{array}$ & 2,353 & 12,726 & 3,327 & 3,807 & 1,194 & 32 & 18 & 19 & 56 & 7 & 381 & 3 & 13 & -294 & 1,488 & 45 & 484 \\
\hline 1987-Q3 & 0.861 & 0.667 & 18,624 & 1,070 & 12,835 & 3,602 & 3,807 & 1,179 & 25 & 11 & 19 & 64 & 10 & 441 & 2 & 14 & -306 & 1,485 & 36 & 323 \\
\hline 1987-Q4 & 0.861 & 0.673 & 18,562 & 3,339 & 28,770 & 2,597 & 3,807 & 1,105 & 40 & 17 & 18 & 56 & 11 & 1,031 & 4 & 15 & -317 & 1,422 & 48 & 335 \\
\hline 1988-Q1 & 0.874 & 0.679 & 19,253 & 4,260 & 16,283 & 2,781 & 3,807 & 1,186 & 68 & 12 & 25 & 81 & 12 & 574 & 4 & 9 & -322 & 1,508 & 16 & 488 \\
\hline 1988-Q2 & 0.874 & 0.686 & 19,764 & 206 & 14,044 & 2,814 & 3,807 & 1,170 & 45 & 26 & 27 & 54 & 5 & 456 & 0 & 13 & -335 & 1,505 & 426 & 743 \\
\hline 1988-Q3 & 0.874 & $\begin{array}{l}0.690 \\
0.694\end{array}$ & $\begin{array}{l}19,5384 \\
19,538\end{array}$ & 2,064 & $\begin{array}{r}14,444 \\
12,756\end{array}$ & $\begin{array}{l}2,014 \\
2,758\end{array}$ & $\begin{array}{l}0,807 \\
3,807\end{array}$ & 1,159 & 35 & 18 & 24 & $\begin{array}{l}54 \\
83\end{array}$ & 10 & 434 & 2 & 17 & -350 & $\begin{array}{l}1,009 \\
1,509\end{array}$ & $\begin{array}{l}400 \\
16\end{array}$ & 259 \\
\hline 1988-Q4 & 0.874 & 0.701 & 19,335 & 3,239 & 18,201 & 2,749 & 3,807 & 1,074 & 63 & 13 & 17 & 49 & 10 & 557 & 6 & 20 & -364 & 1,438 & 14 & 274 \\
\hline 1989-Q1 & 0.873 & 0.710 & 19,935 & 2,733 & 14,740 & 2,829 & 3,807 & 1,155 & 67 & 19 & 15 & 97 & 8 & 459 & 3 & 12 & -373 & 1,528 & 13 & 760 \\
\hline 1989-Q2 & 0.873 & 0.719 & 20,427 & 2,533 & $\begin{array}{l}14,726 \\
13,726\end{array}$ & $\begin{array}{l}3,0<01 \\
3,00\end{array}$ & $\begin{array}{l}3,807 \\
3,87\end{array}$ & 1,142 & 42 & 21 & 17 & 78 & 9 & 417 & 0 & 9 & -382 & 1,524 & 44 & 713 \\
\hline $1989-\mathrm{Q} 3$ & 0.873 & 0.723 & 20,357 & 3,173 & 14,424 & 3,222 & 3,807 & 1,127 & 43 & 11 & 19 & 67 & 8 & 392 & 2 & 13 & -393 & 1,520 & 26 & 199 \\
\hline 1989-Q4 & 0.873 & 0.729 & 20,313 & 991 & 14,307 & 3,143 & 3,807 & 1,061 & 64 & 17 & 25 & 42 & 9 & 524 & 0 & 7 & -400 & 1,461 & 19 & 428 \\
\hline 1990-Q1 & 0.876 & 0.740 & 20,740 & 970 & 14,709 & 2,965 & 3,807 & 1,109 & 53 & 9 & 21 & 70 & 6 & 528 & 1 & 13 & -412 & 1,521 & 6 & 653 \\
\hline 1990-Q2 & 0.876 & 0.748 & 20,886 & 1,103 & 9,949 & 3,112 & 3,807 & 1,100 & 43 & 13 & 22 & 57 & 7 & 467 & 2 & 4 & -414 & 1,514 & 21 & 505 \\
\hline 1990-Q3 & 0.876 & 0.758 & 20,670 & 785 & 14,452 & 2,852 & 3,807 & 1,105 & 28 & 16 & 9 & 36 & 11 & 615 & 1 & 4 & -417 & 1,522 & 20 & 174 \\
\hline 1990-Q4 & 0.876 & 0.767 & 20,731 & 368 & 9,457 & 2,690 & 3,807 & 1,041 & 48 & 5 & 20 & 35 & 13 & 678 & 3 & 6 & -420 & 1,461 & 1 & 404 \\
\hline 1991-Q1 & 0.871 & 0.773 & 20,433 & 434 & 6,613 & 3,095 & 3,807 & 1,059 & 39 & 13 & 28 & 30 & 17 & 353 & 1 & 3 & -422 & 1,481 & 28 & -58 \\
\hline 1991-Q2 & 0.871 & 0.777 & 20,151 & 66 & 7,477 & 3,254 & 3,807 & 1,058 & 19 & 10 & 18 & 41 & 25 & 287 & 0 & 2 & -424 & 1,482 & 6 & -119 \\
\hline 1991-Q3 & 0.871 & 0.783 & 19,993 & 415 & 5,098 & 3,371 & 3,807 & 1,046 & 24 & 6 & 15 & 28 & 20 & 296 & 2 & 7 & -429 & 1,475 & 5 & 169 \\
\hline 1991-Q4 & 0.871 & 0.789 & 20,203 & 198 & 6,904 & 3,442 & 3,807 & 998 & 31 & 5 & 10 & 37 & 21 & 367 & 0 & 5 & -434 & 1,432 & 6 & 306 \\
\hline 1992-Q1 & 0.871 & 0.795 & 20,281 & 242 & 8,301 & 3,647 & 3,807 & 1,060 & 28 & 26 & 15 & 40 & 18 & 296 & 2 & 6 & -438 & 1,498 & 42 & 208 \\
\hline 1992-Q2 & 0.871 & 0.800 & 20,765 & 42 & 9,024 & 3,599 & 3,807 & 1,088 & 14 & 19 & 11 & 55 & 16 & 341 & 2 & 2 & -438 & 1,526 & 36 & 512 \\
\hline 1992-Q3 & 0.871 & 0.806 & 20,738 & 19 & 9,744 & 3,598 & 3,807 & 1,086 & 13 & 11 & 13 & 40 & 21 & 392 & 1 & 5 & -442 & 1,528 & 31 & 174 \\
\hline 1992-Q4 & 0.871 & 0.811 & 20,836 & 199 & 7,099 & 3,7 & 3,807 & 1,042 & 31 & 10 & 14 & 32 & 13 & 411 & 0 & 9 & -451 & 1,493 & 40 & 159 \\
\hline 1993-Q1 & 0.860 & 0.815 & 20,409 & 178 & 14,310 & 3,854 & 3,807 & 1,073 & 20 & 9 & 17 & 67 & 23 & 326 & 2 & 3 & -452 & 1,525 & 5 & -158 \\
\hline 1993-Q2 & 0.860 & 0.820 & 20,640 & 1,170 & 8,862 & 3,882 & 3,807 & 1,092 & 19 & 20 & 11 & 46 & 11 & 356 & 0 & 12 & -464 & 1,556 & 18 & 308 \\
\hline 1993-Q3 & 0.860 & 0.823 & 20,564 & 696 & 7,375 & 3,997 & 3,807 & 1,088 & 9 & 10 & 11 & 44 & 18 & 346 & 6 & 8 & -466 & 1,554 & 12 & -23 \\
\hline 1993-Q4 & 0.860 & 0.828 & 20,640 & 650 & 9,028 & 4,194 & 3,807 & 1,034 & 25 & 6 & 14 & 34 & 13 & 378 & 3 & 20 & -483 & 1,517 & 10 & 215 \\
\hline 1994-Q1 & 0.862 & $\begin{array}{l}.0 .830 \\
0.831\end{array}$ & $\begin{array}{l}20,856 \\
20,856\end{array}$ & 95 & $\begin{array}{l}8,0<0 \\
8,084\end{array}$ & 4,261 & $\begin{array}{l}3,807 \\
3,807\end{array}$ & $\begin{array}{l}1,034 \\
1,064\end{array}$ & 13 & 8 & 15 & $\begin{array}{l}34 \\
61\end{array}$ & 8 & $\begin{array}{l}340 \\
342\end{array}$ & 2 & 13 & $\begin{array}{l}-400 \\
-494\end{array}$ & 1,558 & 4 & 368 \\
\hline 1994-Q2 & 0.862 & 0.835 & 21,219 & 21 & 9,561 & 4,072 & 3,807 & 1,074 & 8 & 12 & 11 & 49 & 4 & 417 & 2 & 4 & -496 & 1,570 & 9 & 465 \\
\hline 1994-Q3 & 0.862 & 0.843 & 21,254 & 7 & 11,849 & 4,218 & 3,807 & 1,077 & 9 & 13 & 8 & 48 & 4 & 410 & 4 & 5 & -497 & 1,574 & 8 & 284 \\
\hline 1994-Q4 & 0.862 & 0.847 & 21,536 & 107 & 16,118 & 4,233 & 3,807 & 1,043 & 18 & 16 & 11 & 40 & 2 & 509 & 4 & 10 & -503 & 1,546 & 13 & 461 \\
\hline
\end{tabular}




\begin{tabular}{|c|c|c|c|c|c|c|c|c|c|c|c|c|c|c|c|c|c|c|c|c|}
\hline 1995-Q1 & 0.858 & 0.851 & 21,966 & 241 & 15,252 & 4,404 & 3,807 & 1,104 & 22 & 22 & 11 & 61 & 10 & 483 & 6 & 7 & -504 & 1,608 & 47 & 500 \\
\hline 1995-Q2 & 0.858 & 0.855 & 22,445 & 139 & 26,127 & 4,791 & 3,807 & 1,094 & 14 & 13 & 12 & 61 & 9 & 443 & 3 & 10 & -511 & 1,605 & 161 & 574 \\
\hline 1995-Q3 & 0.858 & 0.859 & 22,526 & 82 & 17,458 & 5,205 & 3,807 & 1,078 & 13 & 5 & 12 & 49 & 4 & 408 & 3 & 16 & -524 & 1,602 & 21 & 402 \\
\hline 1995-Q4 & 0.858 & 0.863 & 22,905 & 179 & 18,081 & 5,471 & 3,807 & 1,035 & 22 & 8 & 10 & 47 & 9 & 518 & 5 & 12 & -531 & 1,566 & 12 & 424 \\
\hline 1996-Q1 & 0.859 & 0.868 & 23,191 & 435 & 19,887 & 5,797 & 3,807 & 1,049 & 18 & 8 & 17 & 63 & 6 & 505 & 3 & 24 & -552 & 1,601 & 57 & 556 \\
\hline 1996-Q2 & 0.859 & 0.874 & 23,742 & 71 & 22,438 & 6,218 & 3,807 & 1,030 & 12 & 6 & 12 & 45 & 10 & 489 & 2 & 30 & -580 & 1,610 & 9 & 638 \\
\hline 1996-Q3 & 0.859 & 0.877 & 23,790 & 71 & 24,227 & 6,030 & 3,807 & 1,019 & 10 & 3 & 7 & 36 & 6 & 596 & 6 & 17 & -591 & 1,610 & 2 & 285 \\
\hline 1996-Q4 & 0.859 & 0.883 & 24,046 & 140 & 24,654 & 6,542 & 3,807 & 985 & 20 & 6 & 8 & 38 & 4 & 600 & 12 & 19 & -598 & 1,583 & 14 & 454 \\
\hline 1997-Q1 & 0.846 & 0.887 & 24,040 & 201 & 30,280 & 6,771 & 3,807 & 1,016 & 21 & 5 & 10 & 61 & 11 & 636 & 10 & 16 & -604 & 1,620 & 3 & 300 \\
\hline 1997-Q2 & 0.846 & 0.889 & 24,952 & 90 & 31,312 & 7,290 & 3,807 & 1,020 & 12 & 4 & 9 & 43 & 11 & 678 & 10 & 5 & -599 & 1,619 & 2 & 858 \\
\hline 1997-Q3 & 0.846 & 0.891 & 24,770 & 14 & 31,125 & 8,206 & 3,807 & 1,003 & 5 & 11 & 10 & 38 & 8 & 523 & 8 & 18 & -609 & 1,612 & 26 & 466 \\
\hline 1997-Q4 & 0.846 & 0.894 & 25,229 & 194 & 43,155 & 8,198 & 3,807 & 966 & 11 & 6 & 6 & 47 & 8 & 643 & 10 & 24 & -623 & 1,589 & 7 & 523 \\
\hline 1998-Q1 & 0.842 & 0.895 & 25,342 & 190 & 33,909 & 8,988 & 3,807 & 1,000 & 9 & 8 & 9 & 47 & 8 & 642 & 10 & 16 & -629 & 1,629 & 34 & 414 \\
\hline 1998-Q2 & 0.842 & 0.896 & 25,895 & 5 & 40,078 & 9,603 & 3,807 & 993 & 8 & 8 & 11 & 41 & 6 & 680 & 4 & 14 & -639 & 1,632 & 7 & 690 \\
\hline 1998-Q3 & 0.842 & 0.899 & 25,399 & 26 & 55,884 & 8,780 & 3,807 & 978 & 3 & 1 & 9 & 37 & 7 & 1,103 & 13 & 15 & -641 & 1,619 & 1 & 209 \\
\hline 1998-Q4 & 0.842 & 0.903 & 25,788 & 124 & 37,861 & 9,917 & 3,807 & 935 & 7 & 2 & 11 & 31 & 12 & 986 & 7 & 17 & -651 & 1,586 & 8 & 534 \\
\hline 1999-Q1 & 0.834 & 0.905 & 25,334 & 171 & 40,062 & 10,920 & 3,807 & 952 & 17 & 4 & 10 & 30 & 12 & 900 & 2 & 17 & -666 & 1,618 & 2 & 507 \\
\hline 1999-Q2 & 0.834 & 0.911 & 26,386 & 119 & 37,974 & 11,533 & $\begin{array}{l}3,807 \\
\end{array}$ & 923 & 9 & 5 & 15 & 28 & 10 & 817 & 1 & 24 & -689 & $\begin{array}{l}1,612 \\
\text { (1) }\end{array}$ & 8 & 390 \\
\hline 1999-Q3 & 0.834 & 0.916 & 25,298 & 263 & 39,319 & 11,478 & 3,807 & 893 & 7 & 3 & 17 & 19 & 4 & 783 & 7 & 19 & -701 & 1,594 & 9 & 282 \\
\hline 1999-Q4 & 0.834 & 0.921 & 25,949 & 129 & 47,326 & 13,057 & 3,807 & 837 & 13 & 4 & 17 & 20 & 13 & 877 & 2 & 28 & -727 & 1,564 & 3 & 115 \\
\hline 2000-Q1 & 0.847 & 0.929 & 25,917 & 275 & 51,756 & 14,303 & 3,807 & 818 & 15 & 3 & 19 & 34 & 15 & 791 & 2 & 31 & -756 & 1,574 & 16 & 1,311 \\
\hline $2000-\mathrm{Q} 2$ & 0.847 & 0.934 & 25,407 & 108 & 37,534 & 13,945 & 3,807 & 826 & 6 & 7 & 11 & 19 & 4 & 744 & 12 & 7 & -751 & 1,577 & 28 & 307 \\
\hline 2000-Q3 & 0.847 & 0.938 & 24,554 & 292 & 37,414 & 14,096 & 3,807 & 803 & 7 & 1 & 14 & 22 & 7 & 706 & 6 & 14 & -759 & 1,562 & 0 & -76 \\
\hline 2000-Q4 & 0.847 & 0.942 & 26,499 & 27 & 39,529 & 12,285 & 3,807 & 766 & 9 & 2 & 18 & 15 & 4 & 804 & 16 & 21 & -764 & 1,530 & 0 & 720 \\
\hline 2001-Q1 & 0.852 & 0.950 & 25,217 & 160 & 30,482 & 11,073 & 3,807 & 776 & 8 & 1 & 18 & 22 & 15 & 605 & 11 & 10 & -763 & 1,539 & 2 & 79 \\
\hline 2001-Q2 & 0.852 & 0.956 & 24,630 & 212 & 28,823 & 10,879 & 3,807 & 757 & 10 & 3 & 11 & 15 & 17 & 533 & 5 & 9 & -767 & 1,524 & 2 & 147 \\
\hline $2001-Q 3$ & 0.852 & 0.957 & 24,972 & 74 & 35,372 & 9,770 & 3,807 & 753 & 4 & 2 & 16 & 22 & 13 & 739 & 8 & 5 & -764 & 1,517 & 2 & 324 \\
\hline 2001-Q4 & 0.852 & 0.959 & 25,629 & 17 & 31,202 & 9,721 & 3,807 & 728 & 6 & 4 & 19 & 15 & 22 & 626 & 3 & 11 & -772 & 1,500 & 22 & 137 \\
\hline 2002-Q1 & 0.863 & 0.961 & 25,102 & 52 & 26,737 & 9,845 & 3,807 & 726 & 9 & 2 & 16 & 18 & 20 & 468 & 3 & 9 & -778 & 1,504 & 2 & 136 \\
\hline 2002-Q2 & 0.863 & 0.967 & 24,915 & 287 & 37,246 & 9,012 & 3,807 & 718 & 10 & 3 & 9 & 24 & 5 & 545 & 10 & 4 & -772 & 1,490 & 2 & 353 \\
\hline 2002-Q3 & 0.863 & 0.972 & 24,964 & 31 & 40,361 & 7,471 & 3,807 & 717 & 6 & 1 & 5 & 19 & 7 & 794 & 4 & 3 & -771 & 1,488 & 16 & 113 \\
\hline 2002-Q4 & 0.863 & 0.976 & 25,604 & 214 & 28,636 & 7,691 & 3,807 & 713 & 6 & 14 & 7 & 16 & 12 & 744 & 2 & 4 & -773 & 1,486 & 38 & 303 \\
\hline $2003-Q 1$ & 0.930 & 0.983 & 26,700 & 149 & 27,388 & 7,189 & 3,807 & 734 & 9 & 14 & 7 & 27 & 4 & 725 & 0 & 4 & -777 & 1,511 & 281 & 394 \\
\hline $2003-Q 2$ & 0.930 & $\begin{array}{l}0.903 \\
0.985\end{array}$ & $\begin{array}{l}20,100 \\
25,629\end{array}$ & $\begin{array}{l}225 \\
225\end{array}$ & $\begin{array}{l}27,000 \\
28,699\end{array}$ & $\begin{array}{l}1,109 \\
8,086\end{array}$ & $\begin{array}{l}3,001 \\
3,807\end{array}$ & $\begin{array}{l}744 \\
741\end{array}$ & 9 & $\begin{array}{l}14 \\
17\end{array}$ & 3 & $\begin{array}{l}21 \\
28\end{array}$ & $\begin{array}{l}4 \\
3\end{array}$ & $\begin{array}{l}588 \\
588\end{array}$ & 2 & $\begin{array}{l}4 \\
3\end{array}$ & -778 & $\begin{array}{r}1,519 \\
1,519\end{array}$ & 66 & $\begin{array}{l}794 \\
779\end{array}$ \\
\hline $2003-Q 3$ & 0.930 & 0.989 & 26,269 & 872 & 34,071 & 8,646 & 3,807 & 772 & 23 & 46 & 9 & 40 & 7 & 500 & 1 & 0 & -777 & 1,549 & 213 & 338 \\
\hline 2003-Q4 & 0.930 & 0.992 & 29,514 & 915 & 42,790 & 9,396 & $\begin{array}{l}3,807 \\
3,0\end{array}$ & 803 & 21 & 40 & 8 & 61 & 6 & 501 & 0 & 2 & -779 & 1,582 & 379 & 1,036 \\
\hline 2004-Q1 & 0.930 & 1.000 & 28,357 & 826 & 43,363 & 9,802 & 3,807 & 842 & 25 & 33 & 4 & 76 & 6 & 485 & 1 & 3 & -781 & 1,623 & 139 & 832 \\
\hline 2004-Q2 & 0.930 & 1.008 & 29,094 & 1,392 & & 9,763 & 3,807 & 848 & 20 & 24 & 11 & 67 & 2 & & 1 & 0 & -780 & 1,628 & 158 & 1,136 \\
\hline
\end{tabular}

Notes: Data sample consists top 3,807 CRSP firms (ranked by market capitalization) which are non financial, non utilities, and non foreign in their last quarter.

Col. (2) is the tax preference parameter from Poterba (2004). It is defined as the average of (1-tdiv)/(1-tcg) where tdiv is marginal tax rate on dividend income and tcg is the marginal tax rate on capital gains.

Col. (3) is the Consumer Price Index (base 1 in 2004-Q1). All amounts are expressed in real 2004-Q1 dollars. Col. (4) is the total amount of regular dividends. Col. (5) is the total amount of special dividends

Col. (6) is the total amount of share repurchases computed with data93 item in the COMPUSTAT quarterly data (purchases of com

Col. (11) is the number of regular dividend initiations defined as starting to pay regular dividends after not having paid for 4 quarters ( 6 quarters if annual payer).

Col. (12) is the number of regular dividend terminations defined as stopping regular dvides payt

Col. (13) (resp. (14)) are the number of intensive reg. div, increases (resp. decreases) by at least $20 \%$ in real terms in quarter $\mathrm{t}$ (relative to quarters $\mathrm{t}-1$ and $\mathrm{t}-4$ ). Dividend initiations are not counted as intensive increases or decreases. Col. (15) is the number of firms repurchasing at least $0.1 \%$ of their shares in the quarter.

Col. (16) is the number of firms which enter the core sample and are paying regular dividends. Col. (17) is the number of firms leaving the core sample and which were regular dividend payers.

(18) is the cumulated difference between columns (16) and (17). Column (19) is col. (9) minus col. (18): it captures the number of payers controlling for entry and exit effects.

Col. (20) is the amounts of regular dividend initiations defined as starting to pay regular dividends after not having paid for 4 quarters (6 quarters if annual payer)

The solid line marks the time at which the tax reform was enacted (end of May 2003) and the dashed line the time at which the tax reform was retrospectively applied (January 1st, 2003) 
Table A3

Heterogeneity Results: Annualized Initiation Rates Pre and Post Reform by Quintile

\begin{tabular}{|c|c|c|c|c|c|c|c|}
\hline \multirow[t]{2}{*}{ Variable } & Period & \multicolumn{5}{|c|}{ Quintile } & \multirow{2}{*}{$\begin{array}{c}\text { Diff-in-Diffs } \\
\text { q5 vs. q1 }\end{array}$} \\
\hline & & 1 & 2 & 3 & 4 & 5 & \\
\hline & Pre & 0.20 & 0.29 & 0.62 & 0.58 & 1.91 & \\
\hline Largest Fraction of Shares & & $(0.10)$ & $(0.12)$ & $(0.20)$ & $(0.19)$ & $(0.42)$ & \\
\hline among Executives & Post & $\begin{array}{c}3.55 \\
(0.93)\end{array}$ & $\begin{array}{c}3.20 \\
(0.82)\end{array}$ & $\begin{array}{c}3.81 \\
(0.95)\end{array}$ & $\begin{array}{c}4.68 \\
(1.09)\end{array}$ & $\begin{array}{c}9.49 \\
(1.89)\end{array}$ & $\begin{array}{c}4.22 \\
{[0.0314]}\end{array}$ \\
\hline & Pre & 0.88 & 0.94 & 0.41 & 0.43 & 0.73 & \\
\hline Largest Option (Unexercisable) & & $(0.25)$ & $(0.25)$ & $(0.15)$ & $(0.16)$ & $(0.23)$ & \\
\hline Holding among Executives & Post & $\begin{array}{c}8.43 \\
(1.77)\end{array}$ & $\begin{array}{c}5.91 \\
(1.26)\end{array}$ & $\begin{array}{c}4.41 \\
(1.02)\end{array}$ & $\begin{array}{c}2.87 \\
(0.83)\end{array}$ & $\begin{array}{c}3.96 \\
(1.03)\end{array}$ & $\begin{array}{c}-4.31 \\
{[0.0277]}\end{array}$ \\
\hline Largest Option (Exercisable) & Pre & $\begin{array}{c}1.13 \\
(0.28)\end{array}$ & $\begin{array}{c}0.66 \\
(0.20)\end{array}$ & $\begin{array}{c}0.73 \\
(0.23)\end{array}$ & $\begin{array}{c}0.54 \\
(0.19)\end{array}$ & $\begin{array}{c}0.31 \\
(0.14)\end{array}$ & \\
\hline Holding among Executives & Post & $\begin{array}{c}8.38 \\
(1.68)\end{array}$ & $\begin{array}{c}5.42 \\
(1.14)\end{array}$ & $\begin{array}{c}3.07 \\
(0.82)\end{array}$ & $\begin{array}{c}4.62 \\
(1.18)\end{array}$ & $\begin{array}{c}4.22 \\
(1.08)\end{array}$ & $\begin{array}{c}-3.34 \\
{[0.0813]}\end{array}$ \\
\hline Percentage of Shares & Pre & $\begin{array}{c}0.76 \\
(0.21)\end{array}$ & $\begin{array}{c}0.76 \\
(0.20)\end{array}$ & $\begin{array}{c}0.56 \\
(0.17)\end{array}$ & $\begin{array}{c}0.85 \\
(0.21)\end{array}$ & $\begin{array}{c}0.65 \\
(0.18)\end{array}$ & \\
\hline Held by Institutional Investors & Post & $\begin{array}{c}2.73 \\
(0.68)\end{array}$ & $\begin{array}{c}3.05 \\
(0.71)\end{array}$ & $\begin{array}{l}3.55 \\
(0.77)\end{array}$ & $\begin{array}{c}4.64 \\
(0.89)\end{array}$ & $\begin{array}{c}10.72 \\
(1.35)\end{array}$ & $\begin{array}{c}8.09 \\
{[0.0000]}\end{array}$ \\
\hline Two-year Forecasted & Pre & $\begin{array}{c}1.13 \\
(0.57)\end{array}$ & $\begin{array}{c}0.58 \\
(0.41)\end{array}$ & $\begin{array}{c}0.61 \\
(0.43)\end{array}$ & $\begin{array}{c}1.12 \\
(0.56)\end{array}$ & 0.00 & \\
\hline Earnings Growth & Post & $\begin{array}{l}10.64 \\
(2.69)\end{array}$ & $\begin{array}{l}13.54 \\
(2.96)\end{array}$ & $\begin{array}{c}6.66 \\
(1.98)\end{array}$ & $\begin{array}{c}5.06 \\
(1.89)\end{array}$ & $\begin{array}{c}1.53 \\
(1.08)\end{array}$ & $\begin{array}{c}-7.97 \\
{[0.0003]}\end{array}$ \\
\hline Ratio of Profits to Assets & Pre & 0.00 & $\begin{array}{c}0.15 \\
(0.09)\end{array}$ & $\begin{array}{c}0.51 \\
(0.16)\end{array}$ & $\begin{array}{c}1.29 \\
(0.26)\end{array}$ & $\begin{array}{c}1.67 \\
(0.29)\end{array}$ & \\
\hline & Post & $\begin{array}{c}0.33 \\
(0.24)\end{array}$ & $\begin{array}{l}1.47 \\
(0.49)\end{array}$ & $\begin{array}{l}3.90 \\
(0.79)\end{array}$ & $\begin{array}{c}7.29 \\
(1.12)\end{array}$ & $\begin{array}{c}13.14 \\
(1.50)\end{array}$ & $\begin{array}{c}11.14 \\
{[0.0000]}\end{array}$ \\
\hline Ratio of Debt to Assets & Pre & $\begin{array}{c}0.84 \\
(0.20)\end{array}$ & $\begin{array}{c}0.60 \\
(0.17)\end{array}$ & $\begin{array}{c}0.65 \\
(0.18)\end{array}$ & $\begin{array}{c}0.85 \\
(0.21)\end{array}$ & $\begin{array}{c}0.71 \\
(0.20)\end{array}$ & \\
\hline & Post & $\begin{array}{c}8.23 \\
(1.19)\end{array}$ & $\begin{array}{c}3.27 \\
(0.75)\end{array}$ & $\begin{array}{c}4.28 \\
(0.85)\end{array}$ & $\begin{array}{c}4.57 \\
(0.87)\end{array}$ & $\begin{array}{c}4.94 \\
(0.89)\end{array}$ & $\begin{array}{c}-3.16 \\
{[0.0345]}\end{array}$ \\
\hline Ratio of Cash to Assets & Pre & $\begin{array}{c}1.06 \\
(0.23)\end{array}$ & $\begin{array}{c}0.80 \\
(0.21)\end{array}$ & $\begin{array}{c}0.80 \\
(0.20)\end{array}$ & $\begin{array}{c}0.65 \\
(0.18)\end{array}$ & $\begin{array}{c}0.35 \\
(0.13)\end{array}$ & \\
\hline & Post & $\begin{array}{c}5.67 \\
(0.96)\end{array}$ & $\begin{array}{c}4.04 \\
(0.81)\end{array}$ & $\begin{array}{c}5.73 \\
(0.99)\end{array}$ & $\begin{array}{c}4.46 \\
(0.87)\end{array}$ & $\begin{array}{c}5.35 \\
(0.96)\end{array}$ & $\begin{array}{c}0.39 \\
{[0.7785]}\end{array}$ \\
\hline Assets & Pre & $\begin{array}{c}0.60 \\
(0.19)\end{array}$ & $\begin{array}{c}0.75 \\
(0.19)\end{array}$ & $\begin{array}{c}0.70 \\
(0.19)\end{array}$ & $\begin{array}{c}0.70 \\
(0.19)\end{array}$ & $\begin{array}{c}0.90 \\
(0.21)\end{array}$ & \\
\hline & Post & $\begin{array}{l}2.03 \\
(0.58)\end{array}$ & $\begin{array}{c}3.22 \\
(0.74)\end{array}$ & $\begin{array}{c}4.40 \\
(0.86)\end{array}$ & $\begin{array}{c}5.10 \\
(0.92)\end{array}$ & $\begin{array}{c}10.62 \\
(1.33)\end{array}$ & $\begin{array}{c}8.29 \\
{[0.0000]}\end{array}$ \\
\hline Number of Large Holding & Pre & $\begin{array}{l}1.07 \\
(0.22)\end{array}$ & $\begin{array}{c}0.48 \\
(0.16)\end{array}$ & $\begin{array}{c}0.48 \\
(0.34)\end{array}$ & $\begin{array}{c}0.58 \\
(0.15)\end{array}$ & $\begin{array}{c}0.39 \\
(0.24)\end{array}$ & \\
\hline Outside Shareholders & Post & $\begin{array}{c}4.87 \\
(0.91)\end{array}$ & $\begin{array}{c}4.63 \\
(1.05)\end{array}$ & $\begin{array}{c}1.52 \\
(1.07)\end{array}$ & $\begin{array}{c}4.75 \\
(0.89)\end{array}$ & $\begin{array}{c}6.40 \\
(2.20)\end{array}$ & $\begin{array}{c}2.21 \\
{[0.3419]}\end{array}$ \\
\hline Number of Large Holding & Pre & $\begin{array}{c}0.62 \\
(0.15)\end{array}$ & & & & $\begin{array}{c}1.13 \\
(0.37)\end{array}$ & \\
\hline Independent Directors & Post & $\begin{array}{c}2.18 \\
(0.50) \\
\end{array}$ & & & & $\begin{array}{r}5.76 \\
(1.63) \\
\end{array}$ & $\begin{array}{c}3.06 \\
{[0.0543]}\end{array}$ \\
\hline
\end{tabular}

NOTE-See Figures 14-16 and text for description of sample and quintile construction procedure. Pre-reform period is 2001-Q3 to 2002-Q4; post-reform is 2003-Q1 to 2004-Q2. Standard errors clustered by firm reported in parens. Diffs-in-diffs column reports pre-post change in initiation rate in q5 minus corresponding change in q1, with $\mathrm{p}$-values for F-test in square brackets. For earnings growth, diffs-in-diffs column compares q5 and q2. For indep. directors, q1 contains all firms with no large-shareholding indep directors and q5 contains all other firms. 
Table A4

Heterogeneity Results: Initiation Rates Pre and Post Reform by Quintile Conditional on Controls

\begin{tabular}{|c|c|c|c|c|c|c|c|}
\hline \multirow[t]{2}{*}{ Variable } & \multirow[t]{2}{*}{ Period } & \multicolumn{5}{|c|}{ Quintile } & \multirow[t]{2}{*}{ Test: q5-q1 } \\
\hline & & 1 & 2 & 3 & 4 & 5 & \\
\hline & Pre & 0.27 & 0.33 & 0.74 & 0.53 & 1.70 & \\
\hline Largest Fraction of Shares & & $(0.27)$ & $(0.33)$ & $(0.74)$ & $(0.53)$ & $(1.70)$ & \\
\hline among Executives & Post & $\begin{array}{c}3.79 \\
(1.08)\end{array}$ & $\begin{array}{c}3.20 \\
(0.96)\end{array}$ & $\begin{array}{c}4.44 \\
(1.06)\end{array}$ & $\begin{array}{c}5.19 \\
(1.28)\end{array}$ & $\begin{array}{l}10.37 \\
(2.05)\end{array}$ & $\begin{array}{c}5.14 \\
{[0.0222]}\end{array}$ \\
\hline & Pre & 0.64 & 1.02 & 0.47 & 0.52 & 0.90 & \\
\hline Largest Option (Unexercisable) & & $(0.32)$ & $(0.29)$ & $(0.18)$ & $(0.19)$ & $(0.32)$ & \\
\hline Holding among Executives & Post & $\begin{array}{c}9.03 \\
(1.91)\end{array}$ & $\begin{array}{c}4.88 \\
(1.42)\end{array}$ & $\begin{array}{c}4.73 \\
(1.22)\end{array}$ & $\begin{array}{c}3.26 \\
(0.99)\end{array}$ & $\begin{array}{c}5.27 \\
(1.29)\end{array}$ & $\begin{array}{c}-4.02 \\
{[0.071]}\end{array}$ \\
\hline Largest Option (Exercisable) & Pre & $\begin{array}{c}0.88 \\
(0.36)\end{array}$ & $\begin{array}{c}0.76 \\
(0.23)\end{array}$ & $\begin{array}{c}1.03 \\
(0.28)\end{array}$ & $\begin{array}{c}0.44 \\
(0.24)\end{array}$ & $\begin{array}{c}0.44 \\
(0.20)\end{array}$ & \\
\hline Holding among Executives & Post & $\begin{array}{c}6.96 \\
(1.90)\end{array}$ & $\begin{array}{c}4.95 \\
(1.15)\end{array}$ & $\begin{array}{c}3.95 \\
(1.04)\end{array}$ & $\begin{array}{c}4.54 \\
(1.39)\end{array}$ & $\begin{array}{c}6.68 \\
(1.32)\end{array}$ & $\begin{array}{c}0.16 \\
{[0.9424]}\end{array}$ \\
\hline Percentage of Shares & Pre & $\begin{array}{c}0.77 \\
(0.35)\end{array}$ & $\begin{array}{c}1.29 \\
(0.39)\end{array}$ & $\begin{array}{c}0.33 \\
(0.18)\end{array}$ & $\begin{array}{c}0.79 \\
(0.25)\end{array}$ & $\begin{array}{c}0.62 \\
(0.22)\end{array}$ & \\
\hline Held by Institutional Investors & Post & $\begin{array}{c}2.73 \\
(1.42)\end{array}$ & $\begin{array}{c}5.99 \\
(1.58)\end{array}$ & $\begin{array}{c}2.63 \\
(0.97)\end{array}$ & $\begin{array}{c}4.59 \\
(1.18)\end{array}$ & $\begin{array}{l}10.99 \\
(1.82)\end{array}$ & $\begin{array}{c}8.40 \\
{[0.0003]}\end{array}$ \\
\hline Two-year Forecasted & Pre & $\begin{array}{c}0.95 \\
(0.65)\end{array}$ & $\begin{array}{c}0.24 \\
(0.52)\end{array}$ & $\begin{array}{c}0.24 \\
(0.39)\end{array}$ & $\begin{array}{c}0.52 \\
(0.34)\end{array}$ & $\begin{array}{c}0.08 \\
(0.18)\end{array}$ & \\
\hline Earnings Growth & Post & $\begin{array}{c}4.76 \\
(3.60)\end{array}$ & $\begin{array}{c}6.36 \\
(3.44)\end{array}$ & $\begin{array}{c}1.26 \\
(2.48)\end{array}$ & $\begin{array}{c}0.31 \\
(2.38)\end{array}$ & $\begin{array}{c}0.70 \\
(1.50)\end{array}$ & $\begin{array}{c}-3.19 \\
{[0.1350]}\end{array}$ \\
\hline Ratio of Profits to Assets & Pre & $\begin{array}{c}0.15 \\
(0.20)\end{array}$ & $\begin{array}{c}0.10 \\
(0.14)\end{array}$ & $\begin{array}{c}0.42 \\
(0.21)\end{array}$ & $\begin{array}{c}1.42 \\
(0.37)\end{array}$ & $\begin{array}{c}1.39 \\
(0.37)\end{array}$ & \\
\hline & Post & $\begin{array}{c}3.15 \\
(1.00)\end{array}$ & $\begin{array}{c}1.71 \\
(0.76)\end{array}$ & $\begin{array}{c}4.26 \\
(1.18)\end{array}$ & $\begin{array}{c}6.67 \\
(1.73)\end{array}$ & $\begin{array}{l}11.33 \\
(2.11)\end{array}$ & $\begin{array}{c}6.94 \\
{[0.0019]}\end{array}$ \\
\hline Ratio of Debt to Assets & Pre & $\begin{array}{l}1.09 \\
(0.30)\end{array}$ & $\begin{array}{c}0.64 \\
(0.23)\end{array}$ & $\begin{array}{c}0.53 \\
(0.23)\end{array}$ & $\begin{array}{c}0.72 \\
(0.33)\end{array}$ & $\begin{array}{c}0.48 \\
(0.31)\end{array}$ & \\
\hline & Post & $\begin{array}{c}8.24 \\
(1.80)\end{array}$ & $\begin{array}{c}4.26 \\
(1.07)\end{array}$ & $\begin{array}{c}4.14 \\
(1.25)\end{array}$ & $\begin{array}{c}4.89 \\
(1.61)\end{array}$ & $\begin{array}{c}4.91 \\
(1.44)\end{array}$ & $\begin{array}{c}-2.72 \\
{[0.2486]}\end{array}$ \\
\hline Ratio of Cash to Assets & Pre & $\begin{array}{c}1.36 \\
(0.38)\end{array}$ & $\begin{array}{c}0.76 \\
(0.33)\end{array}$ & $\begin{array}{c}0.79 \\
(0.27)\end{array}$ & $\begin{array}{c}0.55 \\
(0.22)\end{array}$ & $\begin{array}{c}0.31 \\
(0.22)\end{array}$ & \\
\hline & Post & $\begin{array}{c}6.13 \\
(1.63)\end{array}$ & $\begin{array}{c}2.71 \\
(1.39)\end{array}$ & $\begin{array}{c}6.56 \\
(1.57)\end{array}$ & $\begin{array}{c}3.99 \\
(1.13)\end{array}$ & $\begin{array}{c}7.50 \\
(1.79)\end{array}$ & $\begin{array}{c}2.42 \\
{[0.3427]}\end{array}$ \\
\hline Assets & Pre & $\begin{array}{c}0.52 \\
(0.43)\end{array}$ & $\begin{array}{c}0.98 \\
(0.34)\end{array}$ & $\begin{array}{c}0.33 \\
(0.20)\end{array}$ & $\begin{array}{c}0.62 \\
(0.25)\end{array}$ & $\begin{array}{c}1.17 \\
(0.31)\end{array}$ & \\
\hline & Post & $\begin{array}{c}4.96 \\
(1.90)\end{array}$ & $\begin{array}{c}6.10 \\
(1.68)\end{array}$ & $\begin{array}{c}2.62 \\
(1.09)\end{array}$ & $\begin{array}{c}3.13 \\
(1.33)\end{array}$ & $\begin{array}{l}10.84 \\
(1.91)\end{array}$ & $\begin{array}{c}5.24 \\
{[0.0808]}\end{array}$ \\
\hline Number of Large Holding & Pre & $\begin{array}{c}0.92 \\
(0.25)\end{array}$ & $\begin{array}{c}0.51 \\
(0.21)\end{array}$ & $\begin{array}{c}0.67 \\
(0.42)\end{array}$ & $\begin{array}{c}0.71 \\
(0.20)\end{array}$ & $\begin{array}{c}0.80 \\
(0.34)\end{array}$ & \\
\hline Outside Shareholders & Post & $\begin{array}{c}6.53 \\
(1.30)\end{array}$ & $\begin{array}{c}3.84 \\
(1.32)\end{array}$ & $\begin{array}{l}-0.76 \\
(1.60)\end{array}$ & $\begin{array}{c}5.46 \\
(1.18)\end{array}$ & $\begin{array}{c}8.23 \\
(2.85)\end{array}$ & $\begin{array}{c}1.81 \\
{[0.5595]}\end{array}$ \\
\hline Number of Large Holding & Pre & $\begin{array}{c}0.12 \\
(0.39)\end{array}$ & & & & $\begin{array}{c}0.83 \\
(0.41)\end{array}$ & \\
\hline Directors & Post & $\begin{array}{c}1.73 \\
(1.80)\end{array}$ & & & & $\begin{array}{c}6.59 \\
(2.24)\end{array}$ & $\begin{array}{c}4.16 \\
{[0.0971]}\end{array}$ \\
\hline
\end{tabular}

NOTE-Table reports annualized initiation rates by quinitle pre- and post-reform conditonal on observables, using regression specifications as in equation (3) in the text, with key variable of interest excluded from linear control set. Standard errors clustered by firm reported in parentheses. Diffs-in-diffs column reports pre-post change in initiation rate in q5 minus corresponding change in q1, with p-values for F-test in square brackets. For earnings growth, diffs-in-diffs column compares q5 and q2. See Table A3 for additional details. 